\title{
Status of Volcanic Hazard Studies for the Nevada Nuclear Waste Storage Investigations
}

\author{
LA--9325-MS-Vol.2
}

DE86 008326

\author{
B. M. Crowe \\ K. H. Wohletz \\ D. T. Vaniman \\ E. Gladney \\ N. Bower*
}

\section{DISCLAIMER}

This report was prepared an an scconnt of work sponsored by an agency of the United States Government. Nelther the Uaited States Gowermment nor any agency thereof, nor any of their employece, makes any warraty, exprese or implied, of asumes any legal linbility or responsibility for the scouracy, completencen, or usefulnes of any information, apparatu, product, or proceen diveloced, or represcats that its wee would not infringe privately owned rights. Referance bereis to any apecifix commencial product, procene, or aervice by trade name, trademark, manufacturex, of otherwine does not secesserily conetitute or imply its endorement, recommondation, or farories by the United States Government of any ayeacy thereof. The view and opiniom of authors exprewed berein do not secesuarily state or reflect thowe of the United Stales Gowernment of my nevey thereof. 
ABSTRACT . . . . . . . . . . . . . . . . . . . . . 1

I. INTKODUCTION . . . . . . . . . . . . . . . . . . . . . . . . . 2

II. MECHANISM OF EMPLACEMENT OF SHALLOW INTRUSIONS . . . . . . . . . . 3

III. VOLCANIC PATTERNS THROUGH TIME: DV-PR VOLCANIC ZONE . . . . . 4

A. Basaltic Volcanic Fields of the NTS Reginn . . . . . . 5

B. Lunar Crater Volcanic Field. . . . . . . . . . . 19

C. Death Valley Volcanic Field. . . . . . . . . . . . 23

IV. BIMODAL VOLCANISM . . . . . . . . . . . . . . . . 25

V. ORIGIN OF TRACE-ELEMENT-ENRICHED BASALTS . . . . . . . . . . . . 28

vi. HYDROVOLCANIC ACTIVITY . . . . . . . . . . . . . . . 30

A. Field Investigations . . . . . . . . . . . . . . . 31

B. Tephra Studies: Lathrop Wells Basalt Center . . . . . . . 34

1. Particle Size . . . . . . . . . . . . 36

2. Constituent Analyses. . . . . . . . . . . 37

3. Tephra Surface Textures ............... . 38

4. Surface Chemistry .............. . . 40

5. Interpretations............. . . 4 40

C. Crater Dimensions: Hydrovolcanic Centers. . . . . . . . 45

D. Depth and Energy of Explosive Magma/Water Interactions . • . 47

E. Models for Water/Melt Interaction. . . . . . . . . . 49

F. Discussion . . . . . . . . . . . . . . . . . 54

VII. RECOMMENDATIONS .......................... 57

A. Mechanisms of Emplacement of Shallow Intrusions. . . . . . 57

B. Volcanic Patterns Through Time . . . . . . . . . . 57

C. Bimodal Volcanism. . . . . . . . . . . . . . . . 58

D. Origin of Trace-Element-Enriched Basalt. . . . . . . . 58

E. Hydrovolcanic Activity . . . . . . . . . . . . . 58

F. Tectonfic Framework of the NTS Region . . . . . . . . . 59

VIII. REFERENCES . . . . . . . . . . . . . . . . . . . 60

APPENDIX A . . . . . . . . . . . . . . . . . . . . . . 66

APPENDIX B .............................. . . 71

APPENDIX C . . . . . . . . . . . . .......... 76

APPENDIX D . . . . . . . . . . . . ........... 83

APPENDIX E . . . . . . . . . . . ............ 88

APPENDIX F . . . . . . . . . . . . . . . . . . . . . . 99

APPENDIX G . . . . . . . . . . . . . . . . . . . 101 
STATUS OF VOLCANIC HAZARD STUDIES FOR THE NEVADA NUCLEAR

WASTE STORAGE INVESTIGATIONS

by

B. M. Crowe, K. H. Wohletz, D. T. Vaniman, E. Gladney, and N. Bower

\section{ABSTRACT}

Volcanic hazard investigations during FY 1984 focused on five topics: the emplacement mechanism of shallow basalt intrusions, geochemical trends through time for volcanic fields of the Death Valley-Pancake Range volcanic zone, the possibility of bimodal basalt-rhyolite volcanism, the age and process of enrichment for incompatible elements in young basalts of the Nevada Test Site (NTS) region, and the possibility of hydrovolcanic activity. The stress regime of Yucca Mountain may favor formation of shallow basalt intrusions. However, combined field and drill-hole studies suggest shallow basalt intrusions are rare in the geologic record of the southern Great Basin. The geochemical patterns of basaltic volcanism through time in the NTS region provide no evidence for evolution toward a large-volume volcanic field or increases in future rates of volcanism. Existing data are consistent with a declining volcanic system comparable to the late stages of the southern Death Valley volcanic fleld. Drill holes USW VH-l and VH-2 provided no evidence of past bimodal volcanism in the Crater Flat area. The hazards of bimodal volcanism in this area are judged to be low. Two magnetic anomalies, one in Crater Flat and the other near the town of Lathrop Wells, should be drilled to complete documentation of the volcanic history of the Yucca Mountain region and to further test for burled rhyolite centers. The source of a 6-Myr pumice discovered in alluvial deposits of Crater Flat has not been found. Geochemical studies show that the enrichment of trace elements in the younger rift basalts must be related to an enrichment of their mantle source rocks. This geochemical enrichment event, which may have been metasomatic alteration, predates the basalts of the silicic episode and is, therefore, not a young event. Studies of crater dimensions of hydrovolcanic landforms indicate that the worst case scenario (exhumation of a repository at Yucca Mountain by hydrovolcanic explosions) is unlikely. Theoretical models of melt-water vapor explosions, particularly the thermal detonation model, suggest hydrovolcanic explosions are possible at Yucca Mountain. Additional data are required on the radiological consequences of basaltic eruptions at Yucca Mountain; the preferred eruption model for release calculations would open with an episode of hydrovolcanic activity followed by a sustained Strombolian eruption. 


\section{INTRODUCTION}

The status of volcanic hazard studies for the Nevada Nuclaar Waste Storage Investigations (NNWSI) was described by Crowe et al. Tnat report summarized volcanic hazard studies through March of 1983. It also included discussions of areas of uncertainty in the volcanism studies where further work ic required to complete hazard assessment, including:

(1) the emplacewent mechanism of shallow basalt intrusions;

(2) geochemical trends through time of volcanic fields of the Death Valley-Pancake Range (DV-PR) volcanic zone;

(3) the possibility of future bimodal basalt-rhyolite volcanism in the Crater Flat area; and

(4) the timing and mechanisms for incompatible element enrichment of basaltic rocks in the southern DV-PR volcanic zone.

Data and conclusions for the volcanic hazard studies were presented at a review meeting of the US Nuclear Regulatory Commission, Denver, Colorado, in October of 1983. At this meeting, two additional topics of possible uncertainty in the hazard studies were discussed:

(5) the possibility of hydrovolcanic explosions associated with intrusion of basalt magma beneath the Yucca Mountain site; and

(6) the possibility that the DV-PR volcanic zone could represent the incipient stage of an evolving intracontinental rift zone.

In this report, we discuss the results of studies completed following the October 1983 review meeting. The first five topics listed above are explored. The sixth topic, the question of rift evolution, requires data on the tectonic setting of Yucca Mountain and the southern Great Basin, as well as the geophysical characteristics of the DV-PR volcanic zone. Data on the tectonic setting is sumarized in Carr ${ }^{2}-a$ report that was issued after this paper was completed. Geophysical studies by the US Geological Survey are sti1l in progress; therefore, the question of rift evolution will be discussed in subsequent report. 


\section{MECHANISM OF EMPLACEMENT OF SHALLOW INTRUSIONS}

Crowe et al. ${ }^{3}$ summarized evidence concerning the subsurface geometry of basalt feeder systems in the southern Great Basin. They suggested that the prevalent feeder structure exposed in dissected basalt centers is narrow linear dikes. However, a number of exceptions were noted: (1) the Paiute Ridge area in the Halfpint Range in the eastern NTS region, ${ }^{1}$ (2) an area in the Funeral Mountains, west of the Amargosa Valley, and (3) the middle and southern tuff rings of Nye Caryon, also in the eastern NTS region. The Paiute Ridge area provides a well-documented example of shallow basalt intrusions (Crowe et $a l{ }^{3}$ ). Here, Paleozoic and Cenozoic rocks are intruded by sills, discordant intrusions, and saucer-shaped bodies within the floor of a northwest-trending graben. These intrusions are locally associated with scoria cones and lava flows, indicating that magma was extruded at the surface.

The potential disrupting effects of sill and lopolithic intrusions on a repository were not considered in volcanic consequence analyses. Such effects could change considerably the results of consequence analyses for the Yucca Mountain site because of the greater potential for incorporating waste in a magmatic intrusion. There is evidence against formation of sills and . lopoliths beneath basalt centers. (1) Dikes are the most common feeder structures exposed in eroded basalt centers; sills and lopoliths are rare. ${ }^{3}$ (2) No basalt intrusions were noted in alluvium or bedrock in Drill Holes USW $\mathrm{VH}-1$ or $\mathrm{VH}-2$, both of which are located adjacent to the the Red and Black Cone basalt centers in Crater Flat. (3) A 10-Myr basalt intruded as a narrow dike into the Tiva Canyon Member of the Paintbrush Tuff at the western edge of the exploration block (there is no evidence in outcrop that sills or silllike intrusions were fed from the dike). Moreover, formation of shallow intrusions beneath or within a waste repository need not increase the consequences of repository disruption. The intruding basalt could crystallize in the repository tunnel without incorporating waste within magma that was fed to the surface.

Several lines of evidence suggest shallow sill or lopolith intrusions might be possible at the Yucca Mountain site. First, and most important, stress measurements in Drill Hole USW G-2 show a stress regime that favors

ÆInformation recelved from W. J. Carr, US Geological Survey, 1983. 
normal faulting; the magnitude of the least principal stress 18 close to the value at which slip could occur. ${ }^{4}$ Crowe et al. ${ }^{3}$ presented field evidence Indicating that the Palute Ridge intrusions were emplaced contemporaneously with extensional faulting and that extenstonal faulting may have favored formation of lopolithic intrusions. Second, data on the frequency of occurrence of intrusion structures is biased by the level of erosional dissection of basalt centers. It is possible that shallow intrusions are more common in the geologic record but are rarely exposed by erosion.

\section{VOLCANIC PATTERNS THROUGH TIME: DV-PR VOLCANIC ZONE}

Volcanic fields of the DV-PR volcanic zone are divided into two types, Type I and Type II. 1 Type I fields are large-volume with a range of basalt types including basanite, alkali olivine basalt, hawailte, basaltic andesite, and trachyte. These fields are long $\cdots 1$ lived; there was continuous eruptive activity over several million years. The volume of erupted magma at Type I fields is $>10 \mathrm{~km}^{3}$ for the complete field; individual eruptive centers may exceed $2 \mathrm{~km}^{3}$ in volume. Volcanic centers are generally clustered along major, northeast-trending structures, and the volcanic fields have high cone densities $\left(10^{-1}\right.$ to $10^{2}$ vents $\left./ \mathrm{km}^{2}\right)$. Type II volcanic fields are small-volume, having a total magma volume of $<2 \mathrm{~km}^{3}$; individual centers are generally $<0.1 \mathrm{~km}^{3}$ in volume. Volcanic activity in these fields was sporadic: the basalt centers formed during brief cycles of activity separated by longer periods of inactivity. Individual centers are widely scattered, resulting in low cone densities $\left(10^{-3}\right.$ to $10^{-4}$ vents $\left./ \mathrm{km}^{2}\right)$. Basalt types are predominantly hawailte, and there is less alkali basalt and hypersthene-iawailte. 01der basaltic activity in the NTS region ( $>9$ Myr) formed Type I volcanic fields; younger activity ( 9 to $0.3 \mathrm{Myr}$ ) formed Type II fields.

The uncertainty in volcanic hazard studies is whether there is a time progression to the evolution of Type I volcanic fields. Could Type II fields, such as the younger activity of the NTS region, evolve toward Type I volcanic fields through time? Such a temporal change would result in greatly increased rates of volcanism and, therefore, an increase in the projected hazards of future volcanisn. To address this question, we first exandne the temporal patterns of volcanisn in the NTS region and contrast these patterns with long-lived Type I volcanic fields in the DV-PR volcanic zone. 
A. Basaltic Volcanic Fields of the NTS Region

The basaltic rocks of the NTS area are divided into three episodes. Each episode spans several million years and includes basalts erupted from many separate eruptive centers. The volume relations of these episodes vs time are shown in Fig. 1. The oldest episode of basaltic volcanism includes the basalts of the silicic episode (BSE) that erupted during the waning phase of silicic volcanic activity ( 11 to $8.5 \mathrm{Myr}$ ). These basalts form bimodal basalt-rhyolite centers that crop out in a northwest-trending zone extending from the south moat of the Timber Mountain caldera to Stonewall Mountain (Fig. 2). Volumes of basaltic magma for the BSE are large; the individual centers exceed $10 \mathrm{~km}^{3}$. The BSE were replaced gradationally in time by the older rift basalts (ORB). These basalts are either distinctly younger than or spatially separate from the silicic volcanic centers. They consist of small-volume $\left(<1-\mathrm{km}^{3}\right)$ monogenetic Strombolian centers that erupted during the probable peak of extensional faulting. Basalts of this episode range in age from about 9 to 6.5 Myr. Magma volumes declined drastically at the transition between these episodes and then stabilized at low but generally uniform

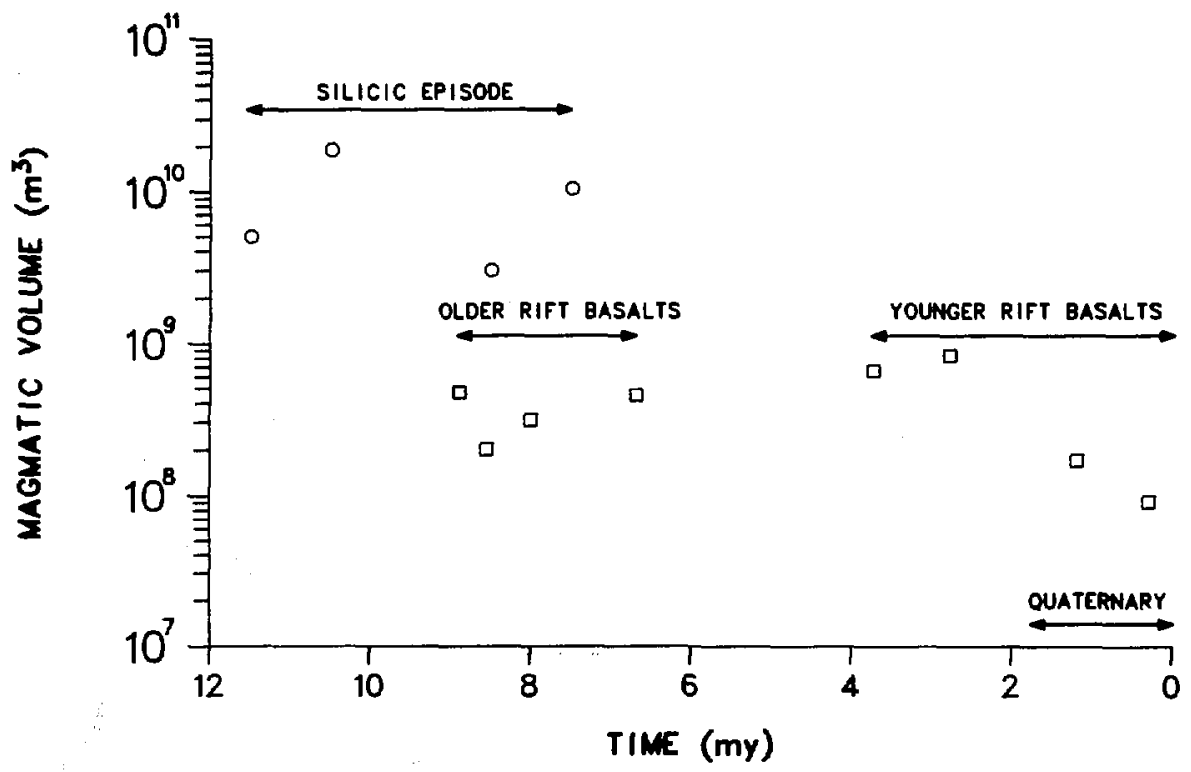

Fig. 1. Plot of volume vs time for volcanic episodes of the NTS region. Volumes for the BSE are average estimates for a 1-Myr period. Volumes of the ORB and YRB are for individual volcanic cycles. 


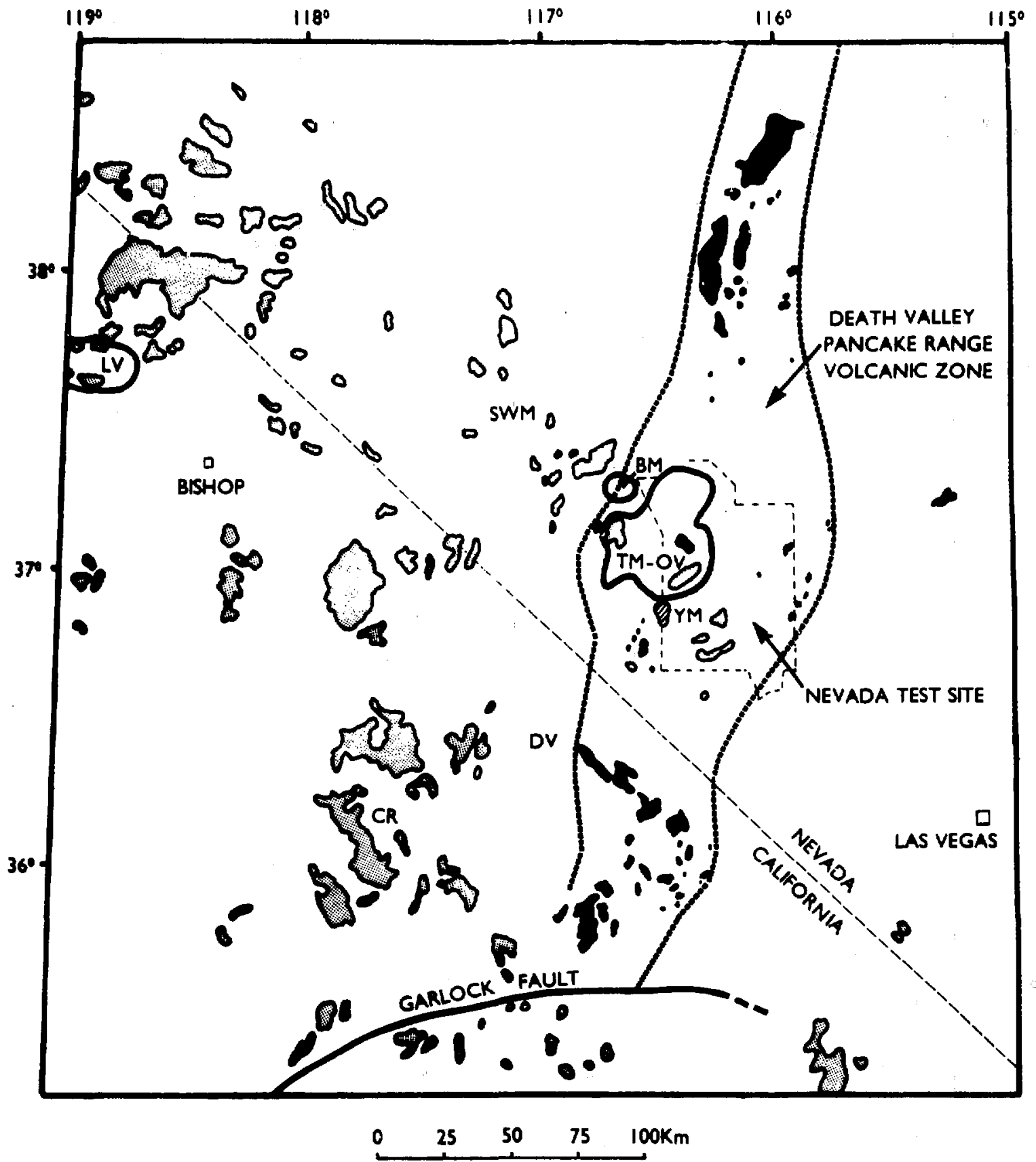

F1g. 2. Generalized geologic map of the DV-PR volcanic zone. SWM: Stonewal1; BM: Black Mountain; TM-OV: Timber Mountain-0asis Valley caldera complex; YM: Yucca Mountain exploration block; LV: Long Valley; DV: Death Valley; and CR: Coso Range. Blackshaded areas are volcanic rocks of the DV-PR volcanic zone; 1ightshaded areas are part of the western Cordillera rift zone. 24 
rates (Fig, 1). There was a brief but important pause in volcanic activity between 6.5 and $3.7 \mathrm{Myr}$. This hiatus was followed by eruption of the younger rift basalts (YRB). These basalts form widely scattered, small-volume centers identical to those of the ORB. They are separated from the ORB on the basis of their younger age ( 3.7 to $0.3 \mathrm{Myr}$ ) and their enrichment in incompatible trace elements (with the exception of rubidium). 5

The mineralogical composition of basaltic rocks of the NTS region was summarized by Crowe et al. 1 They divided the rocks into four major petrological groups, including aphyric to moderately porphyritic olivine basalt, plagioclase porphyritic clinopyroxene-olivine basalt, feldspathic clinopyroxene-olivine basalt, basaltic andesite and trachyte, and quartzbearing clinopyroxene-olivine basalt. Trace phases in the basalts include apatite, kaersutite, and phlogopite (late stage). These trace phases occur in all basalt cycles but are most abundant in the ORB. No other systematic variations in basalt mineraiogy were noted.

Major-element chemical analyses of over 150 basaltic rocks of the NTS region are listed in Appendixes A and B; Appendix C provides trace-element data; and sample descriptions are given in Appendix D. Vaniman et al. ${ }^{5}$ and Crowe et al. ${ }^{1,3}$ emphasized the hawaiite affinity of the majority of the volcanic rocks of the NTS region with emphasis on the basalt of Crater Flat. Significant features of these rocks are their alkaline classification on a $\left(\mathrm{Na}_{2} \mathrm{O}+\mathrm{K}_{2} \mathrm{O}\right) / \mathrm{SiO}_{2}$ diagram, the presence of groundmass olivine and calcic clinopyroxene, the scarcity of groundmass calcium-poor pyroxene, and their andesine-normative feldspar compositions. Vaniman et al. 5 further noted that the majority of analyzed hawaites exhibit the straddle-type association of Miyashiro. ${ }^{6}$ Normative compositions range from slightly nepheline to slightly hypersthene normative and the calculated parental compositions straddle the diopside-olivine join in the basalt tetrahedron diagram. A particularly important petrological feature of these rocks is the increase in normative hypersthene or nepheline with decreasing magnesium number $\left[\mathrm{Mg} /\left(\mathrm{Mg}+\mathrm{Fe}^{2+}\right)\right]$. This suite represents a distinct group of basalts and is a major petrologic rock type throughout the Great Basin and northeast Australia (Best and Brimhal1, ${ }^{7}$ Ewart et: al., ${ }^{8}$ Best and Hamblin, ${ }^{9}$ and Vaniman et al. ${ }^{5}$ ). Using major- and trace-element data from a more comprehensive sample population (see Appendixes $A$ and $B$ ), we now recognize two additional petrologic groups of basalt in the NTS region. These two groups are 
hypersthene hawailte and basaltic andesite. In many petrologic features, hyperthene hawailte is identical to the straddle-type hawailte. Both are classified as alkaline on the total alkalles vs $\mathrm{S}_{1} \mathrm{O}_{2}$ diagram and have andesine-normative feldspar compositions and the mineral assemblage of olivine + calcium-rich clinopyroxene and plagiclase. The hypersthene hawailte differs from the hawaite in three important ways. First, they have higher contents of normative hypersthene ( 7 to $16 \%$ ). As a result, the normative compositions of this rock group cluster toward the center of the ol-hy-di triangle of the basalt tetrahedron. Second, tie hypersthene hawalite more commonly contains groundmass calcium-poor cilnopyroxene. Third, and most important, the hypersthene hawailtes show fractionation trends that differ markedly from the straddle-type hawaittes. Figure 3 is a plot of normative hypersthene and nepheline vs magnesium number for selected

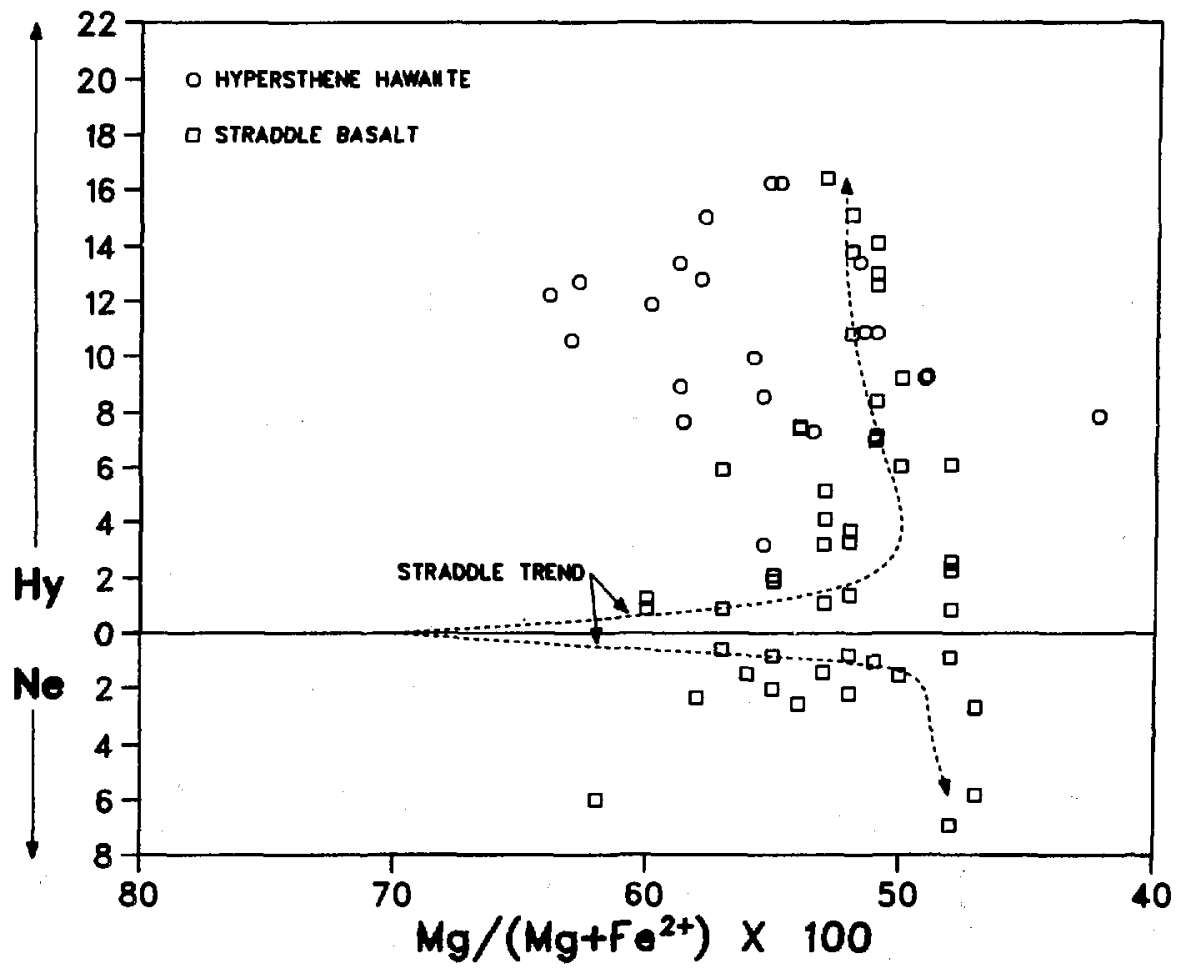

Fig. 3. Plot of nornative hypersthene or nepheline vs magnesium nunber for the straddle basalt and hypersthene hawailte. The dotted lines are calculated fractionation pathways for the straddle basalt. The pathway into the hypersthene field is controlled by amphibole renoval. 4 
basaltic rocks of the NTS region. Not plotted on the diagram are basaltic andesite $\left(\mathrm{SHO}_{2}>53 \mathrm{wt} . \mathrm{x}\right)$ and samples of the older rift basalt. Vaniman et al. 5 have shown that the rocks calculated to be parental to the straddle basalt plot along the olivine-diopside join, and evolved basalt diverges into the nepheline or hypersthene fields with fractionation (straddle trends). The fractionation pathway into the hypersthene field is controlled primarily by amphibole removal, ${ }^{5}$ after which the rocks show decreasing $\mathrm{T}_{1} \mathrm{O}_{2}$ and increasing La/Sm. Three points are important when examining hypersthene hawaite and are illustrated in Fig. 3. First, in normative composition, the straddle-type hawailte overlaps with the hypersthene hawalite at lower magnesium numbers $(<0.55)$. However, the hypersthene hawaite can generally be distinguished from the straddle-type hawailte by its lower La/Sm ratios and higher $\mathrm{TIO}_{2}$ contents. Second, all but one of the occurrences of the hypersthene hawailte are from the silicic eplsode. These rocks, because of their age, are deeply eroded and locally covered by younger ash flow tuff. Outcrops are insufficient for us to reconstruct vent areas and establish detailed correlations. Individual outcrops are uniform geochemically and provide limited evidence of fractionation trends. Geochemical variations between separate units are more pronounced but cannot be related by crystal fractionation using least squares mixing models of the observed phenocryst phases. Variation in the chemical composition of the hypersthene hawaite is most probably a result of differing degrees of partial melting of separate magma pulses. Third, although fractionation trends of individual magma batches cannot be established, the general trend of the rock group is increasingly normative hypersthene with increasing magnesium number. Parental lavas, if present, should plot in the center of the olivinediopside-hypersthene ternary of the basalt tetrahedron. This indicates that the hypersthene hawaite evolved from a different parental basalt than the straddle-type basalt and thus is a separate magma type. Hypersthene hawaite is represented in the basalt analyses of Best and Brimhal1 ${ }^{7}$ and Ewart et a1. 8 but is lumped with the hawailte group. Our work in the NTS region shows that the compositions of evolved hawaite and hypersthene hawalite overlap, but the lavas were derived from separate parental magmas.

The basaltic andesite group comprises basaltic andesite and subordinate basalt that evolve with fractionation toward the quartz-normative side of the basalt tetrahedron. These rocks are associated with large-volume centers and 
mostly with the basalts of the sillcic episode. Major occurrences of the basaltic andesite in the NTS region include the mafic rocks of Dome Mountain, which are plagloclase porphyritic cpx-olivine basalt, basaltic andesite, and minor trachyte, and the mafic rocks of KIwI Mesa, which are sparsely porphyritic basaltic andesite with phenocrysts of olivine, sieve-textured plagloclase, and rare augite and hypersthene. Two other basaltic andesite sultes have unique compositions. The first, the basaltic andesite of skull Mountain, contains phenocrysts of olivine and sieve-textured plagloclase and bipyrimidal quartz that appears to be a cognate phenocryst phase. This sulte is the only assemblage of subalkaline basaltic volcanic rock in the NTS region. 1 The second unusual basaltic andesite is the basaltic andesite of Buckboard Mesa. These mafic rocks are part of the YRB and are the youngest basaltic andesite $1 \mathrm{n}$ the region $(2.8 \mathrm{Myr})$. They contain extremely little normative diopside. Basaltic andesite is common throughout the Great Basin and was recognized as a separate rock group by Best and Brimhall. 7 similar sulte of rocks in Australia was called tholelitic andesite by Ewart et al. 8 The occurrences of the three petrologic groups for each basalt episode are summarized in Table $I$. Their normative compositions are shown in Figs. 4 to 6. The BSE exhibit a diversity of basalt types, including all of the three major basalt groups (Fig. 4). In order of decreasing magma volume, the basalt groups of the BSE are basaltic andesite, hypersthene hawalite, and straddle basalt. In marked contrast, all basalt of the ORB 18 straddle-type basalt and exhibits little compositional variation (F1g. 5). These rocks are the most strongly urisaturated (ne normative) of the NTS region and include basalt that approaches basante in composition. The basalt of Nye Canyon, one of the ORB, is the only known primitive basalt in the region (magnesium number $=0.69$ to 0.74 , nickel content $=240$ to $255 \mathrm{ppm}$, chromium content = 320 to $350 \mathrm{ppm})$. The YRB repeat the BSE pattern of petrologic diversity but show some significant differences. First, the most voluminous petrologic group of this basalt eplsode is the straddle-type basalt; hypersthene hawaite occurs only as a sub-unit of the 3.7-Myr basalt of Crater Flat, and there is only a single basaltic andesite (the basaltic andesite of Buckboard Mesa). Second, the YRB Include highly evolved straddle basalts that appear to have fractionated significant anounts of amphibole. 5 This drives their normative composition toward the hypersthene corner of the basalt tetrahedron 
TABLE I

PETROLOGIC TYPES OF BASALTIC ROCKS FOR THE

NTS REGION LISTED BY BASALT EPISODE

Basalts of the Silicic Episode (11 to $8.5 \mathrm{Myr}$ )

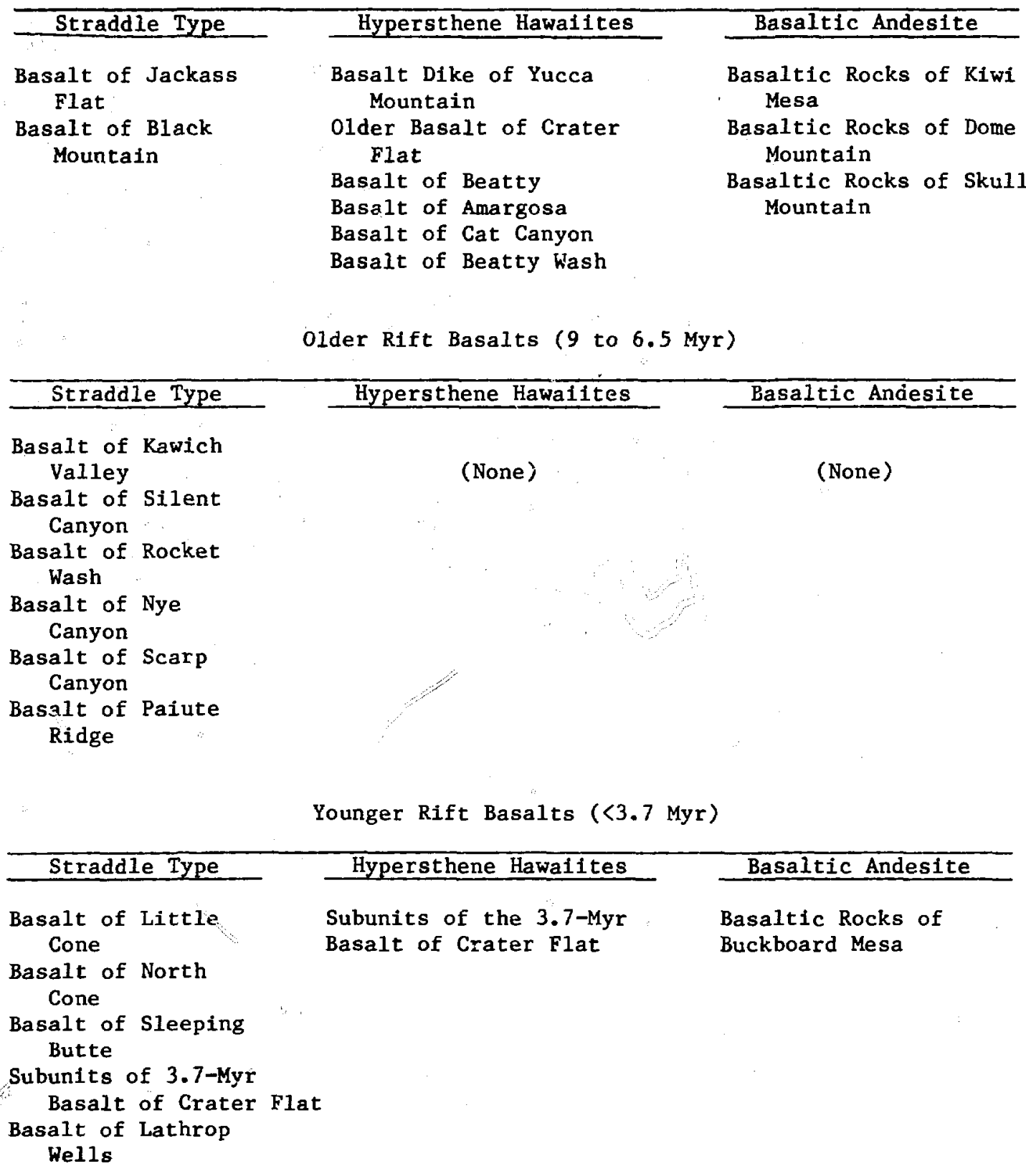




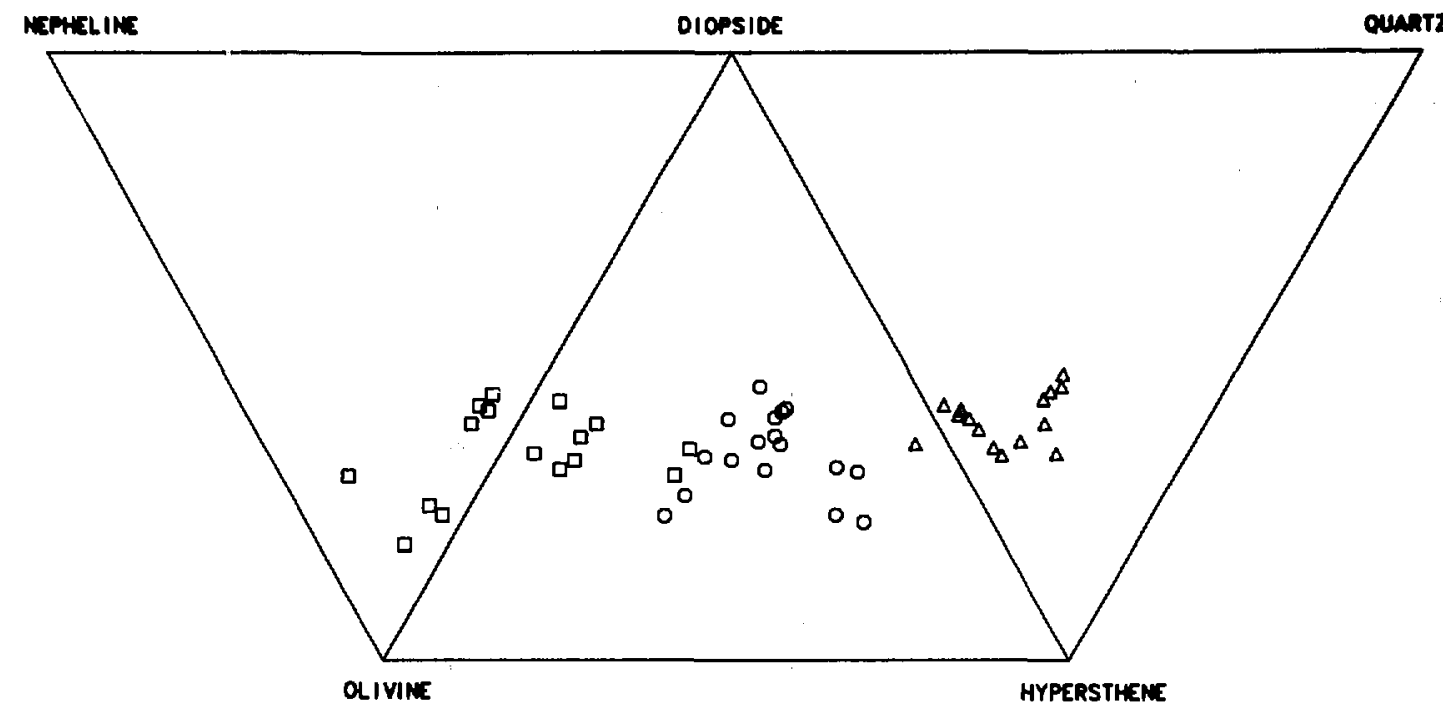

Fig. 4. Normative compositions of the BSE separated by basalt groups. Squares: straddle basalt; clrcles: hypersthene hawailte; and triangles: basaltic andesite.

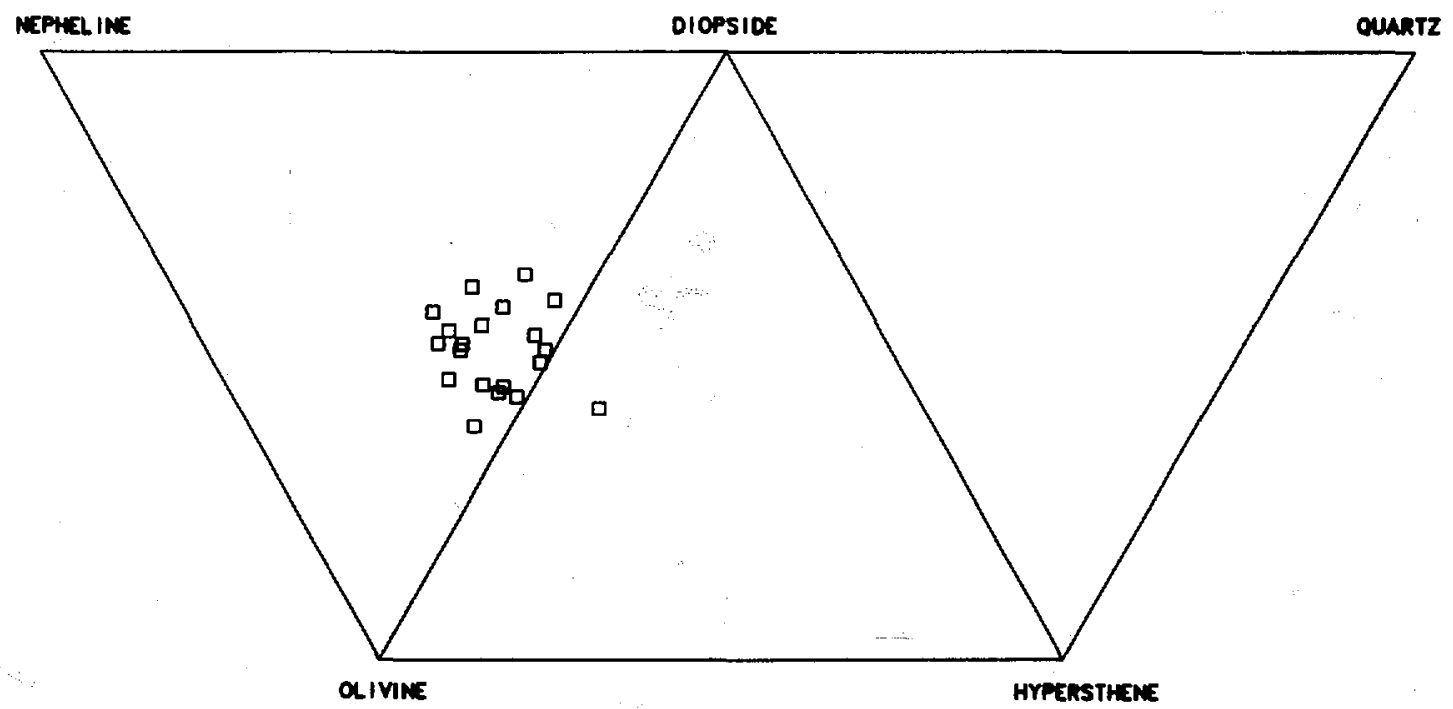

F1g. 5. Nornative compositions of the ORB. All the basalts of the ORB are straddle-type basalt. Symbols are the sane as in Fig. 4. 


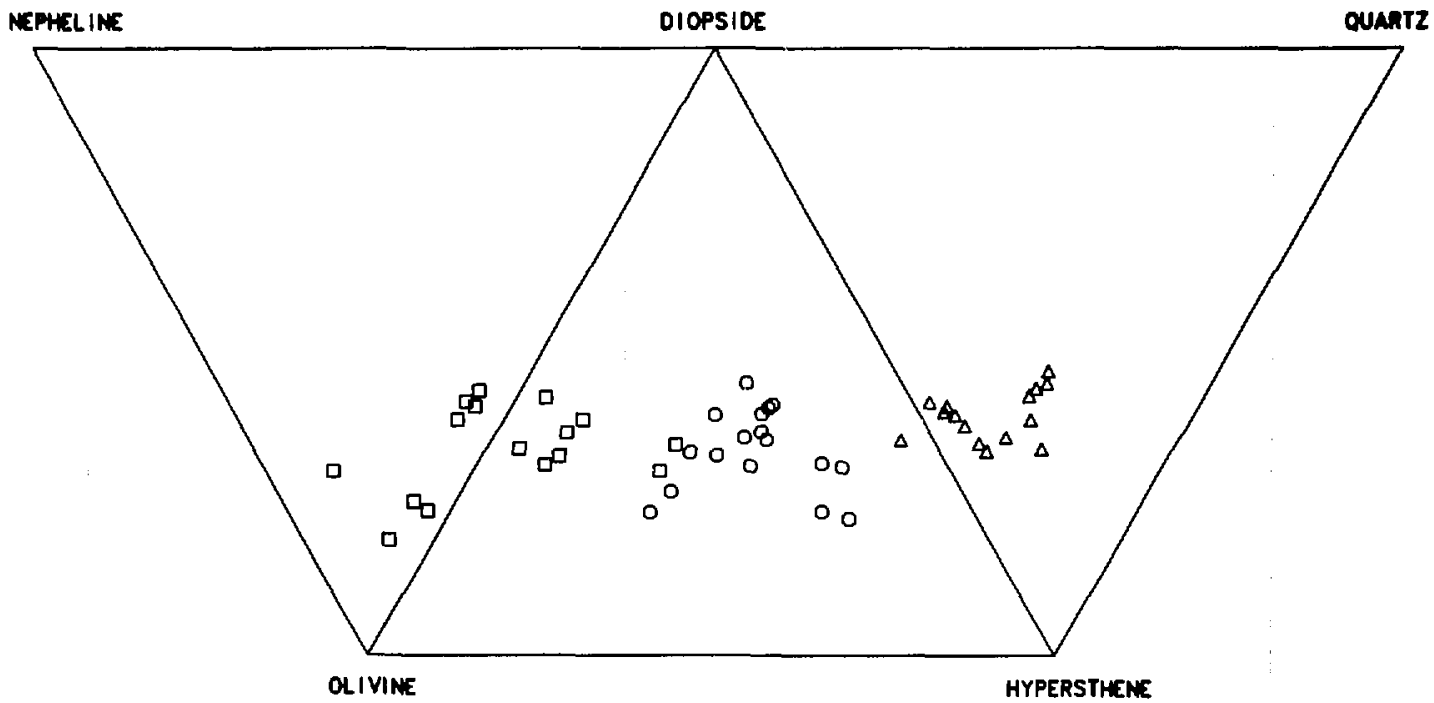

Fig. 6. Normative compositions of the YRB. Symbols are the same as in Fig. 4. The straddle basalt trends across the hypersthene hawaite field as a result of the highly evolved composition and amphibole fractionation. 5

and across the field of hypersthene hawaiite (Fig. 6). Third, as noted earlier, the basaltic andesite of Buckboard Mesa is remarkably poor in normative diopside (Fig. 6). Fourth, all the basalts, with the exception of the basalt of Buckboard Mesa, are small in total erupted volume (about 0.1 $\mathrm{km}^{3}$ ).

The trace-element patterns of the basalts of the NTS region show strong variations with basalt episodes. Two important patterns were noted in previous reports (Vaniman and Crowe, ${ }^{10}$ Vaniman et al., 5 and Crowe et al. ${ }^{1}$ ).

- By comparison to the $\mathrm{ORB}$, the YRB are markedly enriched in incompatible trace elements, with the exception oi rubidium.

- The trace-element contents of the ORB are similar to those of the widespread basalts of the southern Great Basin.

Additional trace-element data have been obtained using combined instrumental neutron activation (INA) and x-ray fluorescence (XRF) analyses for all basalt episodes (Appendix C). Figure 7 is a a plot of incompatible trace elements normalized to midocean ridge basalt (MORB) for all basalt episodes 


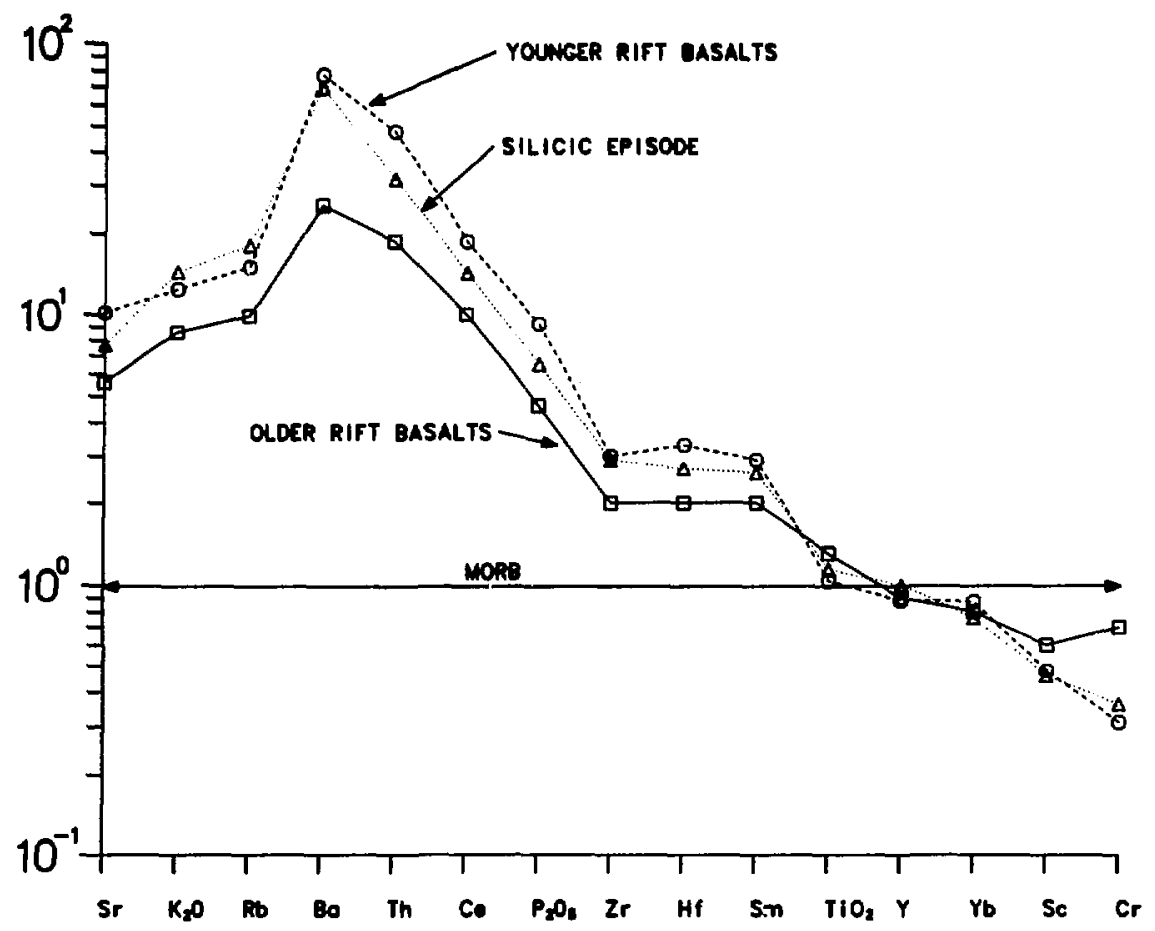

Fig. 7. Incompatible trace-element concentrations of the basalt episodes of the NTS region (normalized to MORB).

of the NTS region (normalization values from Pearce ${ }^{11}$ ). The BSE and the YRB show greater enrichments, by factors ranging from about 1.5 to 3 , relative to MORB than the ORB for the incompatible elements. These variations are too large to be explained by fractional srystallization or by differing degrees of partial melting of an unvarying mantle-source rock. Second, the YRB are slightly more enriched in most incompatible elements than are the basalts of the silicic episode. The most significant differences in enrichments for those groups are for thorium, cerium, $\mathrm{P}_{2} \mathrm{O}_{5}$, and hafnium. The differing degrees of enrichment can be explained either by crystal fractionation or by differing degrees of partial melting. The trace-element data strongly suggest that the YRB and basalts of the silicic episode were derived from a similar mantle source.

Variations in trace-element data (normalized to MORB) for individual basalt episodes in petrologic groups are shown in Figs. 7 to 9. Enrichment patterns are sinflar for the three najor petrologic groups. The nost notable variations are the low thoriun content of the straddle-type basalts for both 


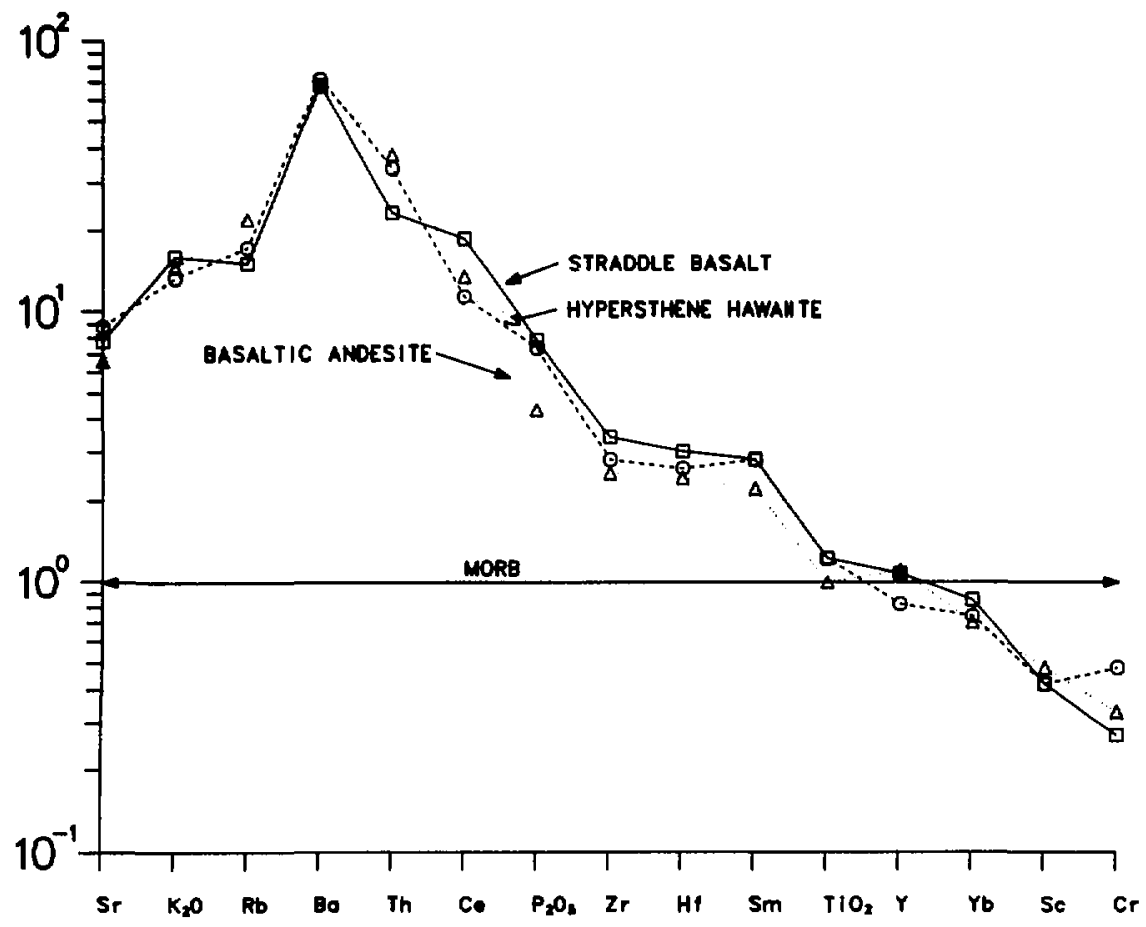

Fig. 8. Incompatible trace-element concentrations of the BSE by petrologic group.

the YRB and the BSE and the moderately high $\mathrm{K}_{2} 0$ and extremely high barium of the basaltic andesites of the YRB.

The systematic trace-element variations between the basalt episodes strongly suggest that the ORB were derived from a different mantle source than either the BSE or the YRB. This theory is supported by isotopic data, particularly data for the isotope systems of strontium and neodymium. Semken $^{12}$ determined the isotopic composition of strontium and neodymium for 11 basalts from the NTS region. These data, listed in Table II, define two isotopic groups. The first group includes high ${ }^{87} \mathrm{Sr} /{ }^{86} \mathrm{Sr}(0.7067$ to 0.7075$)$ and low ${ }^{143} \mathrm{Nd} /{ }^{144} \mathrm{Nd}(0.511313$ to 0.511454$)$ basalts. These basalts show narrow ranges of variations in the two isotopic systems and their neodymium values are extremely low--lower in some cases than those for crustal rocks. The second group has a lower and somewhat more variable ${ }^{87} \mathrm{Sr} /{ }^{86} \mathrm{Sr}$ ratio $(0.70387$ to 0.70471$)$, a higher ${ }^{143} \mathrm{Nd} /{ }^{144} \mathrm{Nd}$ ratio $(0.511949$ to 0.512025$)$, and their isotopic compositions plot in the mantle array. 13,14 


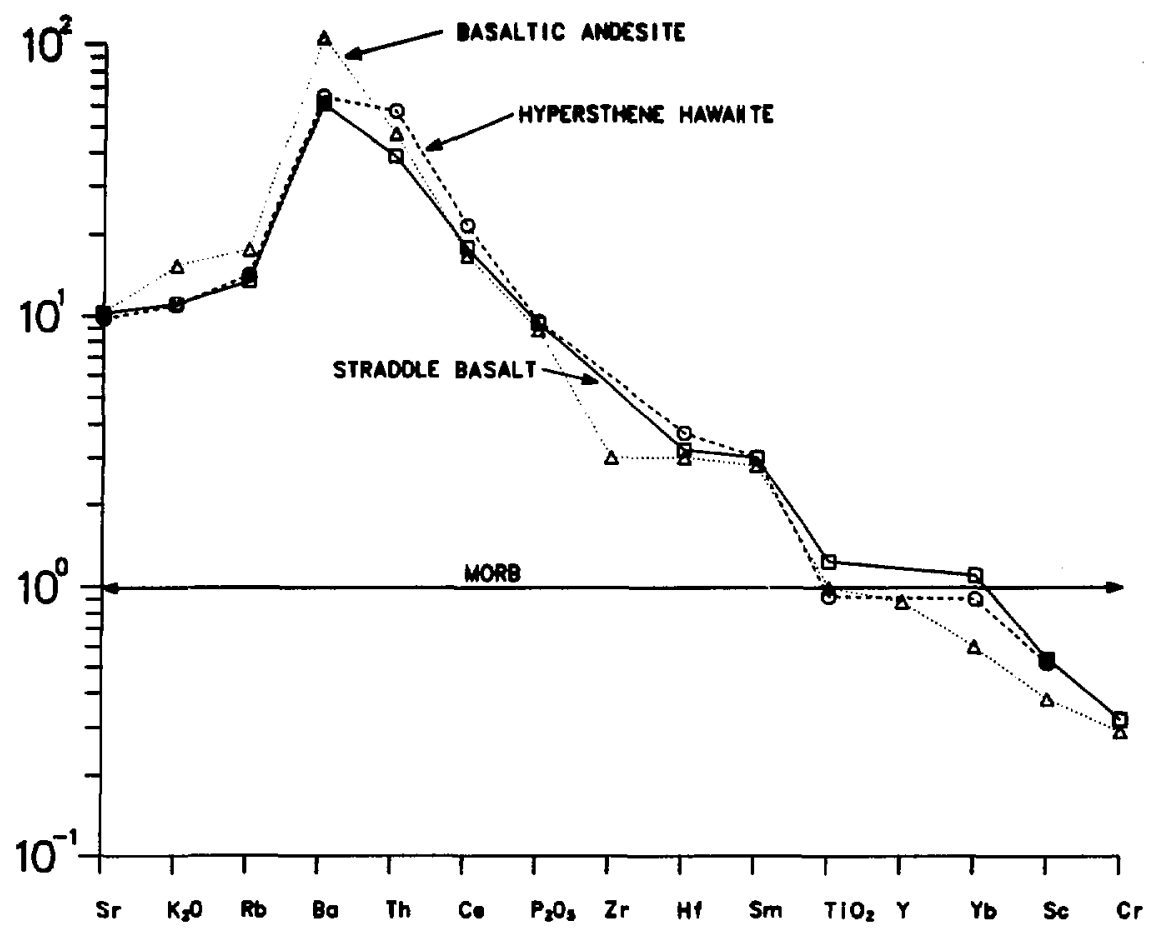

Fig. 9. Iricompatible trace-element concentration of the YRB by petrologic group.

We find a close association, with only two exceptions, between the two isotopic groups and the defined basalt episodes of the NTS region. This closeness is shown on Fig. 10, a plot of chondrite-normalized strontium and neodymium isotopic ratios by basalt episode. All BSE and YRB plot in a narrow area of the diagram corresponding to the first isotopic group. The consistency in isotopic and trace-element composition strongly suggests that the basalts were derived from a similar mantle source. The isotopic composition of the ORB is distinctively different from and somewhat more variable that the composition of the other basalt episodes. This again supports the interpretation that the ORB, with two exceptions, were derived from a different mantle source than that of the YRB and the BSE. The two exceptions are the basalt of Rocket Wash and the basalt of silent Canyon. The basalt of Rocket Wash is an anomaly. It is isotopically identical to the first isotopic group, yet its trace-element patterns overlap with the YRB, BSE, and ORB. It is classified as an ORB on the basis of its age, petrology, and geologic setting. The basalt of Silent Canyon is also classified as an 
TABLE II

ISOTOPIC COMPOSITION OF STRONTIUM AND NEODYMIUM

FOR BASALTIC ROCKS OF THE NTS REGION ${ }^{\mathrm{a}}$

$$
{ }^{87} \mathrm{Sr} /{ }^{86} \mathrm{Sr} \quad \varepsilon \mathrm{Sr} \quad 143 \mathrm{Nd} /{ }^{144} \mathrm{Nd} \quad \text { ENd }
$$

Basalts of the Silicic Eplsode ( 11 to 8.5 Myr)

$\begin{array}{lllll}\text { Basalt of Jackass Flat } & 0.70720 & +38.26 & 0.511396 & -8.61 \\ \text { Older Basalt of Crater Flat } & 0.70725 & +39.07 & 0.511454 & -7.47 \\ \begin{array}{l}\text { Basalt of Black Mountain } \\ \text { Basalt of Black Mountain }\end{array} & 0.7067 & +31.22 & \\ \begin{array}{l}\text { Basaltic andesite, sputhwest } \\ \quad \text { of Black Mountain }\end{array} & 0.7068 & +31.23 & \\ \begin{array}{c}\text { Basaltic aridesite of Dome } \\ \quad \text { Mountain }\end{array} & 0.7075 & +42.58 & \\ \end{array}$

Older Rift Basalts ( 9 to $6.5 \mathrm{Myr}$ )

Basalt of Silent Canyon

Basalt of Rocket Wash

Basalt of Paiute Ridge

Middle basalt of Nye Canyon

Southern basalt of Nye Canyon
$0.70671+31.30$

$0.70709+36.76$

$0.70394:-7.94$

$0.70471 \quad-8.97$

$0.70471+? .91$

0.512025

0.511772

$-1.26$

0.511437

0.512024

$-7.80$

$+3.67$

$+2.20$

$+3.69$

Younger Rift Basalts ( $<3.7 \mathrm{Myr}$ )

Basalt of Sleeping Butte

Basalt of Buckboard Mesa

Basalt of Black Cone

3.7-Myr basalt of Crater Flat

Basalt of Lathrop Wells

$\begin{array}{lllr}0.70698 & +35.26 & 0.511404 & -8.43 \\ 0.70690 & +34.04 & 0.511313 & -10.22 \\ 0.70701 & +35.56 & 0.511374 & -9.02 \\ 0.70747 & +42.21 & 0.511303 & -10.41 \\ 0.70701 & \pm 36.08 & 0.511372 & -9.06\end{array}$

$\overline{a_{\text {From Semken. }}} 12$

$\mathrm{b}_{\text {From Hedge and Noble. }}{ }^{15}$ 


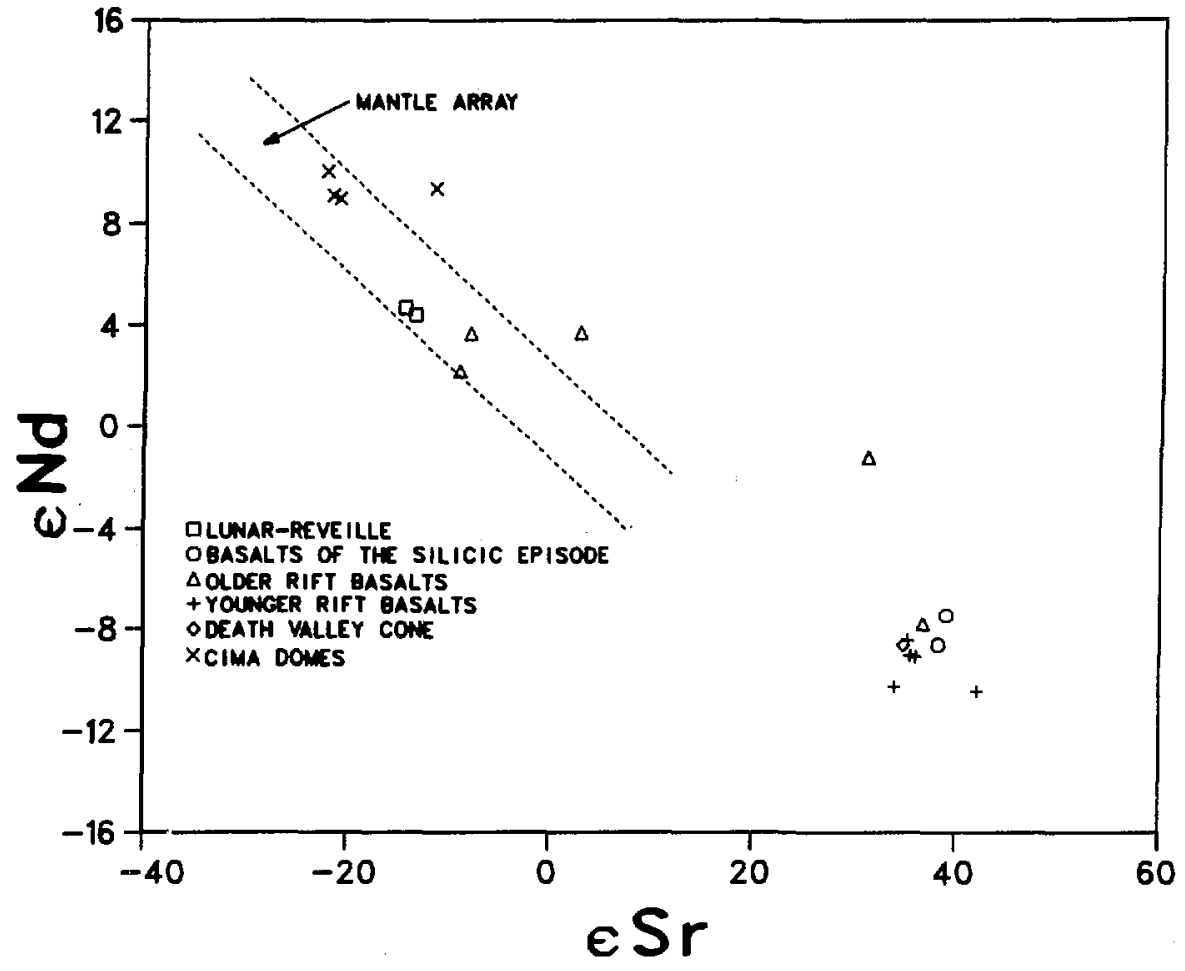

Fig. 10. Epsilon diagram of the strontium and neodynium isotopic compositions of the basaltic rocks of the NTS region by basalt episode (from Semken ${ }^{12}$ ).

ORB on the basis of age, geology, and petrology. This is consistent with the trace-element patterns but not its 1sotopic composition. Compared to the ORB, this basalt has markedly more radiogenic strontium but only slightly lower ${ }^{144} \mathrm{Nd} / /^{143} \mathrm{Nd}$.

To summarize, patterns of basaltic volcanism in the NTS through time are characterized by decreasing volumes and differing patterns of petrologic types of basalt that are associated with two distinct mantle sources. These patterns do not show a systematic time varlation. Patterns astablished by the BSE are not shown by the ORB or the YRB. We next contrast these patterns with the large-volume basalts in the Lunar Crater and southern Death Valley volcantc fields. 


\section{B. Lunar Crater Volcanic Field}

The geology of the Lunar Crater volcanic field was described by Scott ${ }^{16}$ and Scott and Trask. ${ }^{17}$ They established a simple three-fold age subdivision of the volcanic rocks of the field, briefly described the petrology and geochemistry of the lavas, and discussed the geomorphic development of the volcanic landforms. The megacryst and nodule suites in selected lavas of the field have been described in a number of publications (for example, Vitaliano and Harvey, ${ }^{18}$ Trask, $^{19}$ and Pike ${ }^{20}$ ). More recently, Bergman ${ }^{21}$ completed geochemical and petrologic studies of the basalt lavas and nodule and megacryst assemblages. Isotopic studies (lead, strontium, neodymium, and oxygen) of the basalt field are in progress (Foland et al. ${ }^{22}$ ).

We completed geologic mapping of the Lunar Crater volcanic field to further refine the age subdivisions of Scott and Trask ${ }^{17}$ and to examine patterns of volcanism in the field through time. The Lunar Crater volcanic field is the youngest and most active volcanic field of the DV-PR volcanic zone. The scoria centers and associated lavas of the fleld are divided into five classes that are based on degree of erosional dissection of the primary volcanic features, limited measurements of magnetic polarity, and potassiumargon age determinations. These classes, and the criteria for their selection, are listed in Table III. Special care must be taken when using geomorphology to assign relative ages to young volcanic rocks because the rates of erosion are strongly dependent on local topography. We have had fair success, however, in correlating groups of basalt centers within individual volcanic fields. These correlations are more successful between closely grouped centers and are less reliable as the distance between centers increases.

Limited field measurements of the magnetic polarity of lavas in the Lunar Crater field show that groups $Q b 1$ and $Q b 2$ have consistently normal polarity and are probably less than 700000 years old. This is in agreement with a determined date of about $0.6 \mathrm{Myr}$ for the Black Rock Summit flows. A date of $0.38 \mathrm{Myr}$ has also been reported for this flow. * Polarity measurements of the Qb3 lavas are variable and give both reversed and normal polarities for different lavas, suggesting that the lavas of the group are both younger than and older than $0.7 \mathrm{Myr}$. This theory is in agreement with

*From information provided by K. Foland, Ohio State University, 1984. 
TABLE III

VOLCANIC EPISODES OF THE LUNAR CRATER VOLCANIC FIELD

\section{$\mathrm{QB3}$ and $Q \mathrm{C.3}$}

LAVA FLOWS:

Erosional swoothing of flow surface with no retention of flow topography; preserved lava flow fronts.

and complete preservation of lave flow fronts.

\section{SCORIA CONES}

Complete preaervation of cone

craters; undissected cone walls;

\section{EXAYPLE:}

Black Rock Sunit flows and scorts cone and the fissure vents and apatter cones to the north and south.

\section{Q32 and QC2}

LAVA FLOWS :

Lava flow surfaces are smoothed by erosion but retain some Irregulartites of their primary flow surfaces; flow argins are the original lavi flow fronts.

\section{SCORIA CONES:}

Minor erodional rilling of outer cone surfaces.

\section{EXNPLES:}

Eeey Cha1r ecoria cone, tuff cone, and younger lava flow; Lunar Crater tuff ring and explosion crater northese of the tuff ring; corla cowe and lavas northeast of Lunar Crater; tuff cone and lavas of the Lunar Lake cone.

\section{SCORIA CONES:}

Moderate discection of outer cone

Burface ( $>15 \%$ erosional rewoval);

vent or crater form preserved.

\section{EXAMPLES :}

Scorla cones and flows east of Lunar Crater and the cones northeast and southeast of Black Rock Sumat Cone.

\section{$\mathrm{QB4}$ and QC4}

Partial or conplete erosional odificaticin of lava flow fronts; lava vents are not easily recognized on aerial photographs or in the field.

SCORIA CONES:

Major dissection of scoria cones with only partial preservation of cone shape; craters are not easily recognized; scoria deposits are recognirable as cones on aerial photographs.

EXAMPLES :

Scoria cones and flows northeast of Black Rock Sumlt cone; Lava mese and scoria cones south of Lunar Crater.

\section{LAVA FLOWS:}

\section{QB5 and QC5}

LAVAS:

Significant erosion of flows 80 that outcrop distribution 1 sons derably modifled from original coverage; local developaent of Inverse topography.

SCORIA CONES:

Extrene dissection of cones with no preservation of cone shapes; exposure of dikes and sill. in the scoria deposits that form the highest standing parts of the cones; cones cannot generally be recognized on aerial photographs. 
reported ages of 1.2 and $1.5 \mathrm{Myr}$. for group Qb3 flows in, respectively, the northernmost part of the field and $a \mathrm{Qb} 3$ flow in the southern part of the volcanic field. * The age of the Qb4 lavas is partly constrained. The major lava mesa south of Lunar Crater probably correlates with lavas exposed beneath the pyroclastic deposits of Lunar Crater. These lavas yielded a potassium-argon age of about $4 \mathrm{Myr}$, which is probably the approximate age of the mesa lavas. However, new work shows that the mesa lavas south of Lunar Craters may be as young as 1.5 to $2.0 \mathrm{Myr} .^{23}$ Lavas of the Qb5 group have not been dated but are older than the mesa lavas.

Bergman $^{21}$ and Smith and Ludke ${ }^{24}$ recognized a gradual decrease in age of volcanic activity north from the Revel1le Range toward the Lunar Crater volcanic field. Although this migration may be valid on a regional scale, we find other distinct spatial patterns by geomorphic group in the age distribution of the Lunar Crater volcanic rocks. The Qb5 cones and lavas are found only along the ring-fracture zone of the Lunar Crater caldera, primarily along the southeastern side of the caldera. Qb4 lavas and cones occur almost entirely southwest of the south end of the Lunar Crater caldera. The cones for this group, in contrast to the $Q b 5$ cones, show a preferred northnortheast-trending alignment. Groups $\mathrm{Qb3}$ to $\mathrm{Qb} 1$ are confined entirely to north-northeast-trending rift zones within the floor of the Lunar Crater caldera. A time-space pattern emerges: early basaltic volcanism is confined to the caldera wall; it was followed first by a concentration of volcanism along a northeast structure south of Lunar Crater and ther by volcanism along the length of northeast-trending rifts in the floor of the caldera. Major-element geochemical data for the basalts of the Lunar Crater volcanic field are presented by Scott and Trask ${ }^{17}$ and Bergman; ${ }^{21}$ trace- $^{-}$ element data are presented by Bergman. 21 Figure 11 shows normative compositions of the basalts of Lunar Crater by geomorphic group. No analyses are available on cycle 5 basalts. Basalts of cycles 3 and 4 exhibit a range of compositions, including basanite, straddle-type basalt, and hyperstheneto-quartz-normative basalt. In contrast, basalt of cycles 1 and 2 are progressively more undersaturated, and their compositions cluster toward basanite. Isotopic and trace-element data for the Lunar Crater basalt field are summarized in Bergman ${ }^{21}$ and Foland et al. ${ }^{22}$ Analyzed basalt shows

ÆFrom information provided by K. Foland, Ohio State University, 1984. 


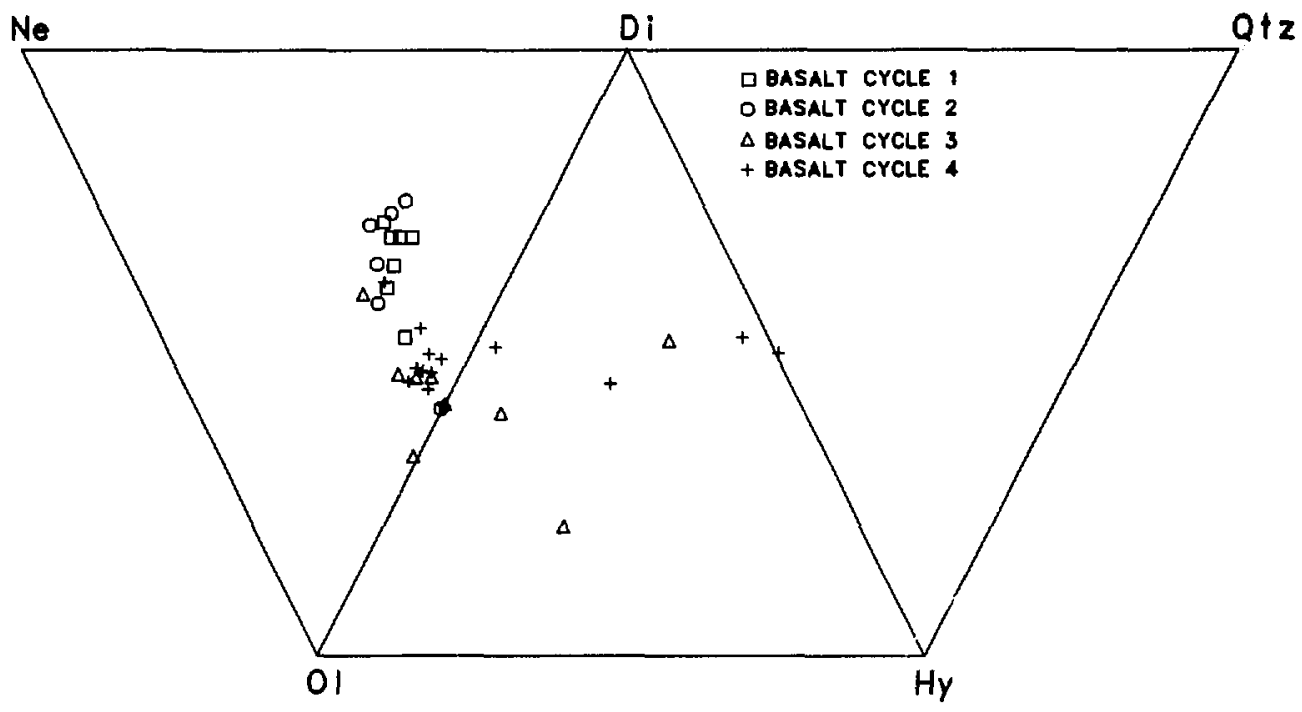

Fig. 11. Normative corpositions of basaltic rocks of the Lunar Crater volcanic field by basalt cycle (data from Scott and Trask ${ }^{17}$ and Bergman ${ }^{1}$ ).

a narrow range in ${ }^{143} \mathrm{Nd} /{ }^{144} \mathrm{Nd}(0.51278$ to 0.51293$)$ and the ${ }^{87} \mathrm{Sr} /{ }^{86} \mathrm{Sr}$ ratios cluster into two groups with values of 0.7030 to 0.7038 and 0.7045 to 0.7051 . These isotopic compositions are similar to the ORB to the south but are very different from the BSE and YRB basalts. The basalts of Lunar Crater show a marked enrichment in light rare-earth elements, although the enrichment is somewhat less than in the $\mathrm{ORB}$ and considerably less than in the silicic and younger rift episodes of the NTS region.

To summarize, the Lunar Crater volcanic field has been an active, large-volume volcanic field since about $4 \mathrm{Myr}$ ago. The presence of numerous basalt centers of Quaternary age as well as the date of 0.38 Myr for the youngest center suggest that this field is still active. Evolution of the basalt field through time was characterized by progressive migration, concentration of volcanism sites along a major system of rift zones crossing the Lunar Crater caldera floor and eruption of increasingly undersaturated alkali basalt and basanite. These patterns are distinctly different from the volcanic patterns of the NTS region. 
C. Death Valley Volcanic Field

The Death Valley volcanic field is located between the Furnace Creek and southern Death Valley fault zones. This volcanic field is unifue for a number of reasons. First, it is located in an amagmatic zone (see Anderson ${ }^{25}$ ), an area between the NTS and the Lake Mead regions with no record of Cenozoic volcanism. Second, the area preserves a complex sequence of older Cenozolc plutonism, volcanism, and tectonism that extends from about 12 to 4 Myr. * Third, in age, volcanic activity in this field overlaps with volcanic activity in the NTS region. Fourth, bimodal silicic and basaltic activity occurred in this region during the time of the volcanic hiatus seen in the NTS region ( 6.5 to $3.7 \mathrm{Myr}$ ). We have confined our field work in the southern Death Valley region to the younger basaltic and silicic rocks of the field. From oldest to youngest, these include a number of established volcanic formations (from Fleck, ${ }^{26}$ Drewes, ${ }^{27}$ MacAlister, 28,29 and Loren Wright.*

- Basalt of Salsberry Pass. These basaltic volcanic rocks crop out in a region extending from the Salsberry Pass area through the central Black Range and the southern part of the Greenwater Range. The unit overlies the Shoshone Volcanic Rocks at Salsberry Pass and locally is interbedded with the lower part of the Greenwater Volcanics in the Greenwater Range. Basaltic volcanic rocks in the northern Black Range that were mapped as part of the Furnace Creek Formation by McAllister ${ }^{28}$ and dated at 7.2 Myr are probably correlative with the basalt of Salsberry Pass. The potassium-argon ages of the basalt of Salsberry Pass range from about 7.5 to 8.0 Myr.

- The Greenwater volcanic rocks consist of rhyodacitic to rhyolitic lava flows, domes, and associated primary and reworked pyroclastic rocks. These rocks crop out throughout the southern and central part of the Greenwater Range and the central part of the Black Range. Their ages range from about 6.5 to $5.3 \mathrm{Myr}$.

- Basaltic volcanic rocks mapped as the Funeral Formation by McAllister ${ }^{28}$ crop out in the northern part of the Greenwater Range. These basalts uncomformably overlie the Greenwater Volcanics and the Furnace Creek Formation. They have been dated at $4.0 \mathrm{Myr}$.

‡Information received from Loren Wright, Pennsylvania State University, 1982. 
- Quaternary basalt crops out at two localities in the valley floor of southern Death Valley where they are Interbedded with alluvial deposits and fanglomerate. These include the basalt of Shoreline Butte, dated at about 1.7 Myr, and the Cinder Hill Cone, dated about 0.7 Myr.

Limited geochemical data are available for these rocks. Major-element data show that all basalt and basaltic andesite of this region are alkaline. A quartz-bearing basaltic andesite is extremely alkaline $\left(\mathrm{Na}_{2} \mathrm{O}+\mathrm{K}_{2} \mathrm{O}=8.7 \%\right.$ for a $\mathrm{SiO}_{2}$ value of 53.64). However, only one analysis is available for this rock type. The Quaternary basalts are slightly more alkaline than other basalts of the Death Valley field. All basalt and basaltic andesite in the Death Valley region are hypersthene or quartz normative and the normative hypersthene contents are generally greater than $9.0 \%$. Additionally, the magnesium numbers of the basalts are generally greater than 0.60 , indicating that the basalts are less evolved than the basalts of the NTS region. The only exception is the Quaternary basalts, which are highly evolved (magnesium number $=0.48$ to 0.51 ). Trace-element patterns also differ between the basalts of the Death Valley volcanic field and the NTS basalts. The former show a wide range of trace-element enrichments that span the ranges of the basalt episodes of the NTS region (Crowe et $a 1^{1}$ ). Moreover, with one exception, there are no distinct spatial or time patterns to the occurrence of trace-element enriched basalts. The exception is the two Quaternary basalt centers of sosthern Death Valley: both are markedly enriched in Incompatible trace elements and are very similar to the YRB of the NTS region. Finally, only limted isotoplc data are avallable for the volcanic rocks of the southern Death Valley region. The isotopic composition of strontium and neodymium for the Cinder Hill cone is identical to that of the BSE and YRB of the NTS region $\left({ }^{87} \mathrm{Sr} /{ }^{86} \mathrm{Sr}=0.70695\right.$ and ${ }^{143} \mathrm{Nd} / 144 \mathrm{Nd}=$ 0.511395 , Semken ${ }^{12}$ ).

To summarize, large-volume basalts were erupted over a period of about 8 Myr In the southern Death Valley fleld. These basalts are hypersthene normative but retain an alkalic character and are most similar to the hypersthene hawaitte of the NTS region. Younger, large-volume basalts ( 4.0 Myr) are also hypersthene normative but show both enriched and nonenriched incom-

\#Information recelved from Loren Wright, Pennsylvania State University, 1982. 
patible trace-element abundances. Following cessation of major volcanism in the southern Death Valley area at about $4.0 \mathrm{Myr}$, two small-volume basalts of Quaternary age were erupted. These basalts are remarkably similar to the YRB, both in their major- and trace-element contents and in the isotopic compositions of strontium and neodymium. These patterns show only one similarity to the volcanic patterns of the NTS region--a transition to trace-element-enriched hawailtes associated with the waning of volcanic activity. No evidence is provided from the geologic record that would indicate the Type II volcanic fields of the NTS region could evolve toward a Type I field like the southern Death Valley volcanic field.

\section{BIMODAL VOLCANISM}

The question of future bimodal volcanism (coexisting basalt-rhyolite magmatic activity) in the NTS region was discussed in earlier reports (Crowe and Carr, ${ }^{30}$ Carr, $^{31}$ and Crowe et al. ${ }^{1}$ ). Bimodal volcanism occurred in the NTS region during the termination of BSE and in the Greenwater Range about 4 to 8 Myr ago in the southern part of the DV-PR volcanic zone. The future occurrence of rhyolite volcanism at Yucca Mountain would Increase the consequences of volcantsm for the following reasons.

- The dimensions of subsurface feeder systems for silicic volcanic activity are larger than those for basalts. Silicic eruptions would incorporate a greater fraction of the waste inventory of a repository. Silicic eruptions are generally more explosive than hasaltic eruptions. Waste entrained in the pyroclastic component of such an eruption would be distributed over a lajer area.

The critical question is whether there is any evidence of rhyolitic volcanism that postdates the Timber Mountain Tuff and/or was associated with the three basalt cycles of Crater Flat $(3.7,1.2$, and $0.3 \mathrm{Myr})$. There is no known occurrence of younger rhyolite volcanic rocks ( $<6 \mathrm{Myr}$ ) in the NTS region; therefore, the risk of future siliclc volcanism was judged to be small (Crowe et al. ${ }^{1}$ ). However, $\operatorname{Carr}^{31}$ reported the presence of silfcic pumice in poorly indurated alluviun exposed beneath $3.7 \mathrm{Myr}$ basalt in southeast Crater Flat. This pumice was dated at $6.3 \mathrm{Myr}$, by the fissiontrack method. No known surface source of silicic volcanic rocks can account 
for the presence of this pumice. Therefore, a logical possible source would be a burled rhyolite center or centers in the Crater Flat area (Crowe and Carr, ${ }^{30}$ and Carr $^{31}$ ).

There is a close correlation between sites of surface basaltic volcanism in the Yucca Mountain reglon and recognized aeromagnetic anomalies (Kane and Bracken $^{32}$ ). Sharply bounded magnetic lows coincide exactly with the four negatively polarized 1.2-Myr basalt centers of Crater Flat (Little Cones, Red Cone, Black Cone, and an unnamed cone north of Black Cone). Somewhat more diffuse but recognizable magnetic lows are associated with the series of negatively polarized, eroded scoria cones and lava flows of 3.7-Myr age in eastern Crater Flat. Two anomalles are located adjacent to and south of Little Cones. The first is a lobate magnetic low that extends to the southeast of Little Cones. This anomaly is inferred to be a basalt flow extruded from the southern cone of Little Cones and now buried by alluvium. Two small outcrops of this lava are exposed adjacent to the southern Little Cones scorla cone. The second anomaly is a clrcular magnetic high located directly south of Little Cones. Crowe and Carr, ${ }^{30}$ Carr, ${ }^{31}$ and Kane and Bracken $^{32}$ inferred this high to be a positively polarized burled basalt center. This inferred center has not been drilled. It may represent a normal event (Jaramillo or Olduval) in the Matuyama reversed epoch, a basalt eruptive cycle correspond1ng to the Gauss Normal Epoch ( 2.5 to $3.4 \mathrm{Myr}$ ), or a pre-Gilbert normal epoch ( $>3.4 \mathrm{Myr}$ )." In the latter two cases, if correctly Interpreted, the anomaly represents a previously unknown cycle of basaltic activity that has not been considered in the interpretations of the volcanic history of Crater Flat (Crowe and Carr, ${ }^{30}$ Vaniman and Crowe, ${ }^{10}$ and Vaniman et al. ${ }^{5}$ ).

Two other magnetic anomalies in Crater Flat are important. A large, lobate magnetic high $1 \mathrm{~s}$ present in the central part of Crater Flat between and west of Black Cone and Red Cone basalt centers. This high was originally Inferred to be a buried basalt of normal magnetic polarity (Crowe and Carr ${ }^{30}$ ). Dril1 Hole USW VH-1 was sited above this positive magnetic anomaly. The hole penetrated shallowly burled basalt lavas that were subsequently dated at $3.7 \mathrm{Myr}$ and shown to be negatively polarized (Carr ${ }^{31}$ ). They could not be the source of the normal magnetic anonaly. Carr ${ }^{31}$ suggeated that the anomaly $1 \mathrm{~s}$ produced by a combination of thickening and resurgent doming of the Bullfrog Member of the Crater Flat Tuff within an Inferred collapee 
caldera. Significantly, no pre-3.7-Myr basalt or silicic volcanic rocks younger than 11 Myr were noted in the drill hole.

The second anomaly of interest is a large dome-shaped magnetic low located at the western edge of Crater Flat. Kane and Bracken ${ }^{31}$ suggesied that this anomaly is probably caused by a thickened accumulation of negatively polarized tuff. Crowe and $\operatorname{Carr}^{30}$ noted that the large amplitude and size of the aeromagnetic anomaly indicated that it could represent a buried silicic dome. Carr ${ }^{31}$ suggested that the anomaly-causing body could be a rhyolite center that was the source of the 6.3-Myr pumice. Drill Hole USW VH-2 was sited between Red Cone and Black Cone along the east flank of the magnetic low. If the anomaly was caused by a silicic dome, the chosen drill hole should have intersected elther the dome or silicic pyroclastic debris shed from the dome. The hole penetrated a sequence of negatively polarized basalt lavas at about $360 \mathrm{~m}$ beneath the surface. The lavas overlie the Timber Mountain Tuff and are overlain in turn by alluvium and slide breccia deposits of Paleozoic rocks. No exotic silicic pyroclastic debris was found in the alluvial section. The basalt lavas were dated at about 11 Myr. * Major- and trace-element analyses of the burled lavas show that they are closely similar in composition to negatively polarized lavas and cone scorla exposed at the southern end of Crater Flat (Appendexes A and B). A previously undescribed magnetic low marks the site of these surface lavas. This low extends as an arcuate magnetic trough from southern Crater Flat south of the Little Cones and connects with the drilled western magnetic low (Kane and Bracken ${ }^{32}$ ). Thus, it appears 11 kely that the lavas of USW VH-2 and southern Crater Flat are related and that this group of lavas underlies much of the western and southwestern parts of Crater Flat.

An additional and potentially important magnetic anomaly, which should be drilled to provide complete characterization of the volcanic history of the Yucca Mountain region, is located southeast of Crater Flat near the town of Lathrop Wells. This anomaly is a sharply bounded magnetic low with a peripheral magnetic high. It was interpreted by Kane and Bracken ${ }^{32}$ to represent a dipole effect from a shallowly buried, single source. They further

*From imformation provided by W. J. Carr, 1984. 
suggested that the source is most probably a volcanic untt, that it becones shallow to the north, and that it is located along a major structural boundary. This anomaly is at the south edge of the published aeromagnetic map of Kane and Bracken, ${ }^{32}$ so 1 ts exact shape is unclear. The amplitude and width of the anomaly indicate it is either an areally extensive basalt or possibly a buried rhyolfte center.

The drill hole data from the two sites in Crater Flat strongly suggest that there are no younger centers of sllicic volcanism burled beneath alluvium in the valley. This indicates that there has not been bimodal volcanic activity in Crater Flat, and therefore, by inference, the potential for future bimodal activity in the area is low. Further exploratory drilling will be required to test whether the magnetic anomaly near Lathrop Wells represents a buried rhyolite center.

\section{ORIGIN OF TRACE-ELEMENT-ENRICHED BASALTS}

Vaniman and Crowe, ${ }^{10}$ Vaniman et a1., ${ }^{5}$ and Crowe et al. ${ }^{1}$ described evidence of a significant enrichment of incompatible trace elements, with the exception of rubidium, in younger basalts of the southern part of the DV-PR volcanic zone. This enrichment is best developed in the YRB of the NTS region. The question, therefore, is whether the trace-element enrichment represents a distinct young event that could be associated with changes in rates of volcanism. Vaniman et al. ${ }^{5}$ reviewed the mechanisms of trace-element enrichment and divided these mechanisms into three categories: (1) mantle metasomatic processes, (2) decreases in the degree of partial melting in the mantle-source regions, and (3) contamination of the basalts during ascent from the mantle by enriched crustal rocks. Arguments against the latter two mechanisms are listed here.

(1) The degree of trace-element enrichment of the basalts is too high to be explained solely by decreasing degrees of partial melting of mantle peridotite.

(2) Neodymium and strontium isotopic data summarized above do not show mixing trends typical of crustal contamination. The 1sotopic compositions of the BRE and YRB are virtually identical. This would not be expected if the basalts had assimilated varying amounts of crust. 
(3) The degree of crustal contamination required to produce the strontium and neodymium isotopic values is very high and should be reflected in even the major-element compositions of the basalts.

(4) The ${ }^{143} \mathrm{Nd} /{ }^{144} \mathrm{Nd}$ values of the basalts are lower than those of many crustal rocks.

(5) The low rubidium values of the basalts severely limit the amount of crustal contamination from most crustal sources. Rubidium is a mobile element during partial melting of crustal rocks.

The remaining process, mantle metasomatism, is a viable albeit illdefined mechanism. Indeed, the role of mantle metasomatism as a causative process in the isotopic and trace-element enrichment of mantle-source rocks and as a mechanism for inducing partial melting of the mantle is currently a much debated topic in petrology (for example, Hawkesworth and Norry ${ }^{33}$ ). Menzies and Murthy ${ }^{34}$ and Menzies ${ }^{35}$ have proposed that mantle metasomatism may be a common precursor to the genesis of alkaline magmas. This raises the question of whether a young metasomatic event is responsible for the generation of the trace-element-enriched YRB of the NTS region. A variety of evidence suggests this is not the case. First, the trace-element-enrichment patterns of the BSE are similar to those of the YRB for most elements (Fig. 7). Minor differences in trace-element contents of the basalt episodes can be explained by varying degrees of source melting and/or crystal fractionation, although there are significant differences in thorium, uranium, cerium, barium, and hafnium. Second, the strontium and neodymium isotopic composition of the two basalt episodes are similar. If the isotopic and trace-element composition of the YRB were produced by a young metasomatic element, the trace-element and isotopic composition of the metasomatic fluids would have to be similar to those of the fluids that altered the mantle before generation of the BSE. Although this is possible, it is more probable that the YRB and BSE were derived from related mantle sources that were altered variably before generation of the BSE. Differences in the trace-element compositions of the BSE and YRB are probably a result of alteration of the mantle associated with and following the voluminous silicic and basaltic activity of the NTS region and basin-range tectonism. 
VI. HYDROVOLCANIC ACTIVITY

Hydrovolcanic activity refers to explosive volcanism that is produced by or accompanies mixing of magma or magmatic heat with an external source of water such as groundwater or surface water (Fisher and Waters, ${ }^{36}$ Sheridan and Wohletz ${ }^{37}$ ). Where rising magma intersects surface water or groundwater, a complex chain of events may take place that can lead to highly energetic explosions. The nature and continuity of explosions are largely dependent upon the rate of thermal energy transfer from the magma to the external water source. This energy transfer results in effects ranging from passive vapor film bolling with quenching and solidification of the magma, to large-scale explosive vaporizations involving superheating instability and detonations of the Chapman-Jouguet $(\mathrm{C}-\mathrm{J})$ and eigenvalue type (Fowles ${ }^{38}$ and Rabie et al. ${ }^{39}$ ). This type of explosive behavior is called fuel-coolant interaction (FCI) and has been studied extensively in nuclear reactor safety.

In volcanic hazard studies for the NNWSI, we have been concerned with the possible importance of hydrovolcanic explostons. Crowe et al. ${ }^{1,3}$ discussed the possibility and potential effects of hydrovolcanic activity if a repository were disrupted by basalt magma. They suggested that hydrovolcanic activity was unlikely at the Yucca Mountain site. This conclusion was based on the considerable depth of the groundwater table and the absence of surface water. Further, Crowe et al. ${ }^{3}$ calculated that the resident moisture of the unsaturated zone was insufficient to allow hydrovolcanic explosions under all but the most extreme ranges of rock saturation. Even under these extremes, the explosions could not be maintained for the duration of eruptive activity. More recently, new data have led to a reexamination of the possibility of hydrovolcanic activity at Yucca Mountain. Detalled mapping of the basalt of Nye Canyon showed that two of the centers exhibited hydrovolcanic activity. Vaniman and Crowe ${ }^{10}$ recognized pyroclastic surge deposits at the Lathrop Wells basalt center and suggested that the early eruptive activity of this center was hydrovolcanic. Field studies of basalt centers in the southern Great Basin show that hydrovolcanic activity is not uncommon. At least seven besalt centers in the Lunar Crater volcanic field exhibited eruptive cycles of hydrovolcanism. Lunar Crater itself is a tuff ring. Ubehebe Craters, located in northern Death Valley, consist of a cluster of tuff rings (Crowe and Fisher ${ }^{40}$ ). We recently discovered pyroclastic surge deposits interbedded with alluvium in southern Death Valley. The source of 
these deposits is one of the two Quaternary basalt centers in the area. The suggestion that the explosive eruption of Mt. St. Helens on May 18, 1980, may have had a hydrovolcanic component (Moore and Sisson $^{41}$ ) has led to considerable increased interest in the mechanisms of hydrovolcanic explosions (Sheridan and Wohletz, ${ }^{42}$ Wohletz and McQueen ${ }^{43}$ ). Perhaps the most important development is the recognition that hydrovolcanic phenomena could occur at considerable depths--in some cases below $5 \mathrm{~km}$ (Sheridan et al. ${ }^{44}$ ).

A number of additional studies were conducted in 1984 to further investigate the possible importance of future hydrovolcanic eruptions at Yucca Mountain. The field evidence for hydrovolcanic activity at basalt centers in the NTS region was examined to provide comprehensive documentation of past activity. Samples of hydrovolcanic deposits from the Lathrop Wells basalt center were collected and studied. We gathered data on the dimensions of hydrovolcanic craters to test the possibility of exhumation of a repository by hydrovolcanic explosions. Finally, we reviewed the mechanisms of magma/vapor explosions to examine the possible controls that depth (pressure) might have on water/magma interactions.

\section{A. Field Investigations}

Generalized geologic maps of the southern and middle centers of the basalt of Nye Canyon are shown in Figs. $12 a$ and $b$. Both centers are composite basalt centers and consist of a main tuff ring infilled by scoria and lava. The largest outcrop of the middle Nye basalt center is a lava lake. This lava lake completely infilled a large, elliptical tuff ring that is elongate in an east-west direction. The maximum length of the tuff ring measured parallel to the axis of the ellipse is $1 \mathrm{~km}$; the maximum width measured perpendicular to the axis is about $0.5 \mathrm{~km}$. Field evidence indicates that the lava lake was confined inside the crater of the tuff ring and was not a lava flow: (1) the lavas are underlain by 2 to $10 \mathrm{~m}$ of cone scoria or hydrovolcanic deposits, indicating that the tuff ring deposits completely encircle the lavas; (2). the contact between the lavas and the cone deposits dips inward toward the center of the lava mass at 15 to $25 \mathrm{ft}$. These dips are concordant with those of the underlying cone deposits, which would imply that the lavas are buttressed against the walls of the tuff ring; and (3) the lavas are more than $73 \mathrm{~m}$ thick but extend for only $1 \mathrm{~km}$. This could 

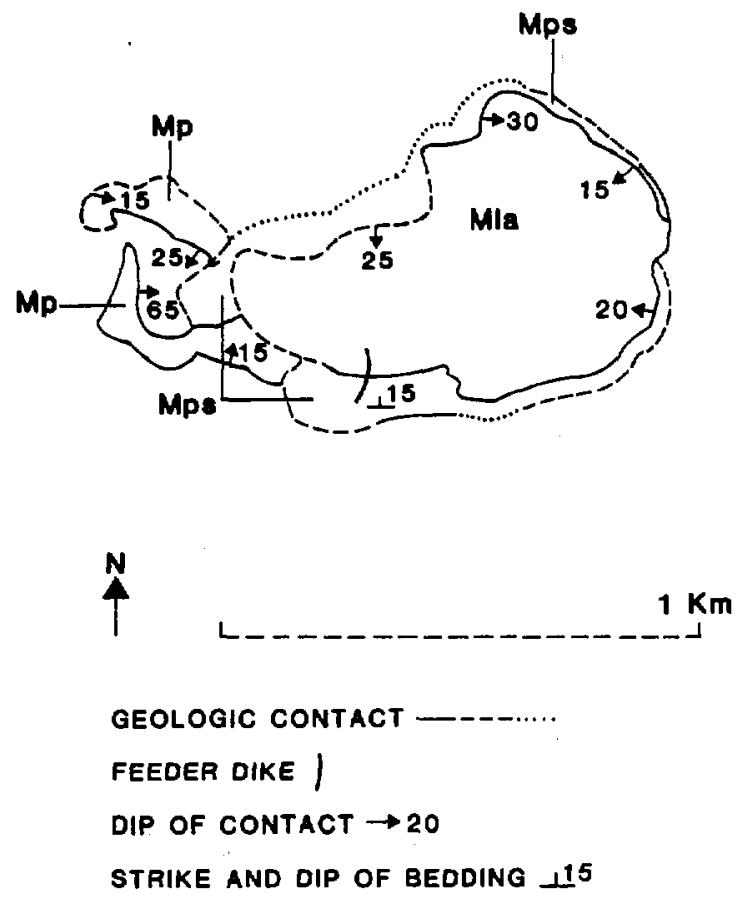

Fig. 12a. Generalized geologic map of the middle Nye center of the basalt of Nye Canyon. Mps: Miocene pyroclastic surge and scorla deposits; Mla: Miocene lava lake; Mp: Miocene basalt plug.

be produced by ponding within highly irregular topography or by ponding within a tuff ring.

The wall of the tuff ring is only locally exposed beneath the lava fill sequence as these deposits were preferentially removed by erosion. The tuff ring deposits are inward dipping except at one locality the south side of the cone where the anticlinal dips of the rim crest are preserved. The tuff ring walls are composed of fine to poorly bedded hydrovolcanic deposits and scorla. The hydrovolcanic materials form the lower part of the section and consist of fine-grained pyroclastic surge deposits. These deposits are composed predominantly of reworked country rock (tuff and minor Paleozoic rocks) with minor basalt ash. Upward in section, there is a gradational increase in grain size and in the abundance of basalt. Here there are two 


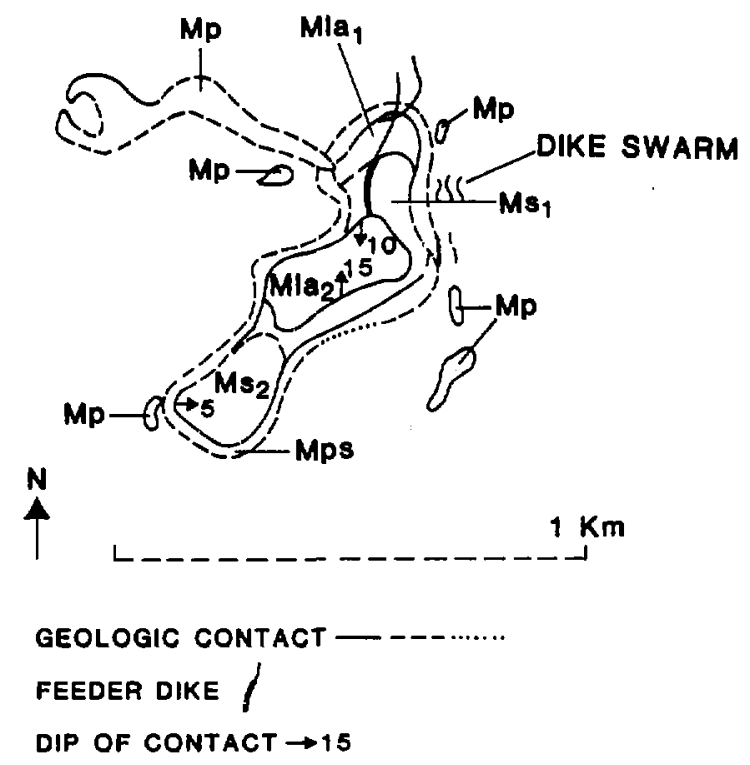

Fig. 12b. Generalized geologic map of the southern Nye Center of the basalt of Nye Canyon. Mps: Miocene pyroclastic surge and scoria deposits; Mla : Miocene lava lake deposits, early cycle; Ms ${ }_{1}$ : Miocene scorta and lava deposits, early cycle; $\mathrm{Ms}_{2}$ : Miocene scoria and lava lake deposits, late cycle; $\mathrm{Mla}_{2}:{ }^{2}$ Miocene lava lake, late cycle; Mp: Miocene basalt plug.

basalt components: fine-grained, palagonitized basaltic ash and coarsegrained basaltic scoria. The fine-grained ash component decreases upward in section, and the upper 2 to $7 \mathrm{~m}$ of the tuff ring are composed of Strombolian scoria. This stratigraphic succession records a progressive decline in the magma-to-water ratio and a transition from hydrovolcanic to Strombolian eruptions when water no longer had access to the vent. The scoria deposits are thickest in the southwest, west, and northwest parts of the outcrop area, indicating localization of a scoria cone in these areas; in the eastern section of the tuff ring, the scoria deposits are not present and the lava lake sequence rests directly on the hydrovolcanic deposits. The probable source of water for the hydrovolcanic activity was a river, which is suggested by the lenses of river gravels preserved beneath the tuff ring. At the eastern end of the basalt center, two lobes of intrusive basalt are 
exposed. These intrusions locally lifted the underlying Paleozoic rocks parallel to the bedding to form sills; they also locally cross-cut the Paleozoic rocks to form large dikes. These dikes intrude the scoria deposits and lava lake in the southeastern edge of the basalt center. They were the major basalt feeder sources for the scorla and lava lake activity.

The southern Nye basalt center (Fig. 12b) is a tuff ring and is similar to the middle Nye center. The center formed at the intersection of a major arcuate dike (exposed west of the center) and a swarm of north-to-northeasttrending dikes and small basalt plugs (exposed on the east flanks of the center). Initial hydrovolcanic activity formed a small tuff ring that is elongate to the northeast. The crater of the tuff ring was infilled by lava and scoria deposits erupted from vents at the southeast and northeast end of the tuff ring. The southeast vent extruded scoria and thin lava flows that were confined entirely within the walls of the crater. The northeast vent formed a small scoria cone that is overlain to the south by a series of ponded lava flows. These flows were fed from a radial dike exposed in the north cliffs of the basalt center.

The geology of the Lathrop Wells basalt center was described by Vaniman and Crowe. 10 The center is composed of a number of coalesced scoria cones flanked on the west by a lavas and on the northwest by pyroclastic surge deposits. We inferred that these pyroclastic surge deposits represent hydrovolcanic eruptions during the early stages of the evolution of the basalt center. Support for this interpretation is provided by the recent discovery of thin-bedded probable hydrovolcanic beds exposed in the southeast quarry wall of the main scoria cone. These deposits are described in more detail in the next section.

\section{B. Tephra Studies: Lathrop Wells Basalt Center}

The methods of analyzing volcanic ash (tephra) have evolved over the last several decades and most recently have incorporated particle size and scanning electron microscopy (SEM) techniques (for example, Walker and Croasdale $^{45}$ and Heiken ${ }^{46,47}$ ). Recently, these techniques have been applied to hydrovolcanic tephra (Wohletz ${ }^{48}$ ) with emphasis on particle-surface chemical analysis by energy dispersive spectral (EDS) analysis. Wohletz 49 demonstrated the correlation of eruption energy to particle size distribution and particle shape to mechanism of particle formation. 


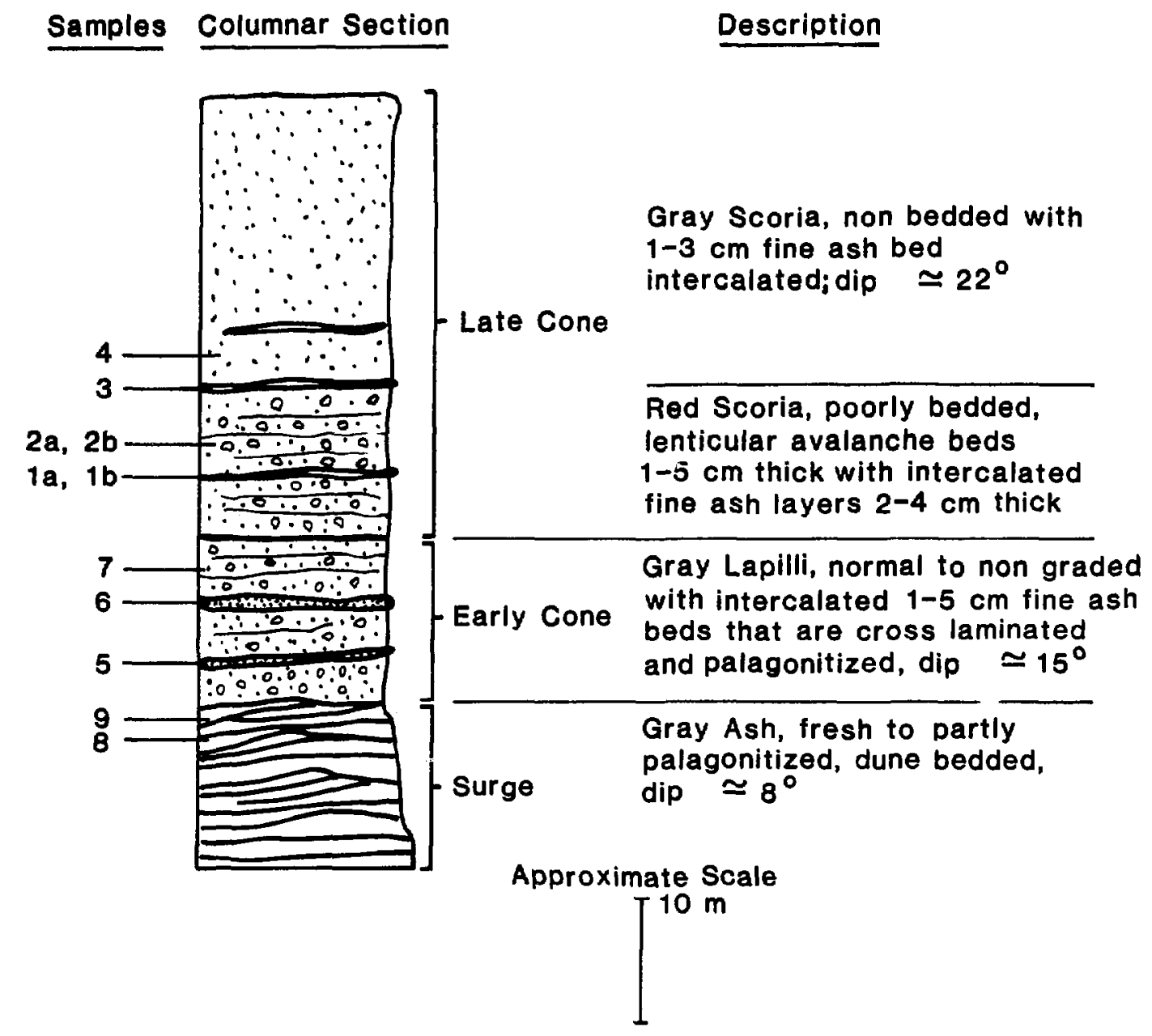

Fig. 13. Stratigraphic column for the Lathrop Wells scoria cone.

Eleven tephra samples were obtained from the Lathrop We11s cone and represent early-to-late-stage eruption products. The stratigraphic column with sampled intervals (Fig. 13) distinguishes three sample types corresponding to finely bedded, locally cross-bedded, pyroclastic ourge deposits, poorly bedded to nonbedded scoria layers, and fine ash layers intercalated with the scorla. Samples were subjected to size, petrographic, SEM, and EDS analysis as described here. Results are shown graphically and 
support the hypothesis of intermittent hydrovolcanic explosions during the early phases of eruptive activity (established by field criteria discussed earlier).

1. Particle Size. Samples were sieved at $1 / 2_{\phi} I_{\phi}=-\log _{2}$ (diameter In millimeters)] intervals from $-3 \phi(8 \mathrm{~mm})$ to $4.5 \phi(0.044 \mathrm{~mm})$ with a standard Tyler sleve set. The contents of each sleve were weighed to $0.1-\mathrm{g}$ accuracy and were saved for later petrographic analysis. The sieve data were analyzed statistically using the MISSOURI particle size analysis code to give data on moments, mean and median diameter, variance and sorting coefficients, skewness, and kurtosis. The data are listed in Appendix E.

Figure 14 is a plot of the Inman ${ }^{50}$ sorting coefficient $\left(\sigma_{\phi}\right)$ vs median diameter (Md $)_{\phi}$. Three fields are outlined for the parameter ranges of the three sample types mentioned above. Surge samples are the finest grained and best sorted; scoria samples are uniformly coarse grained and moderately sorted; and fine ash layers show a wide variation in median diameter and sorting; they are intermediate in particle-size properties when compared to the other two sample types.

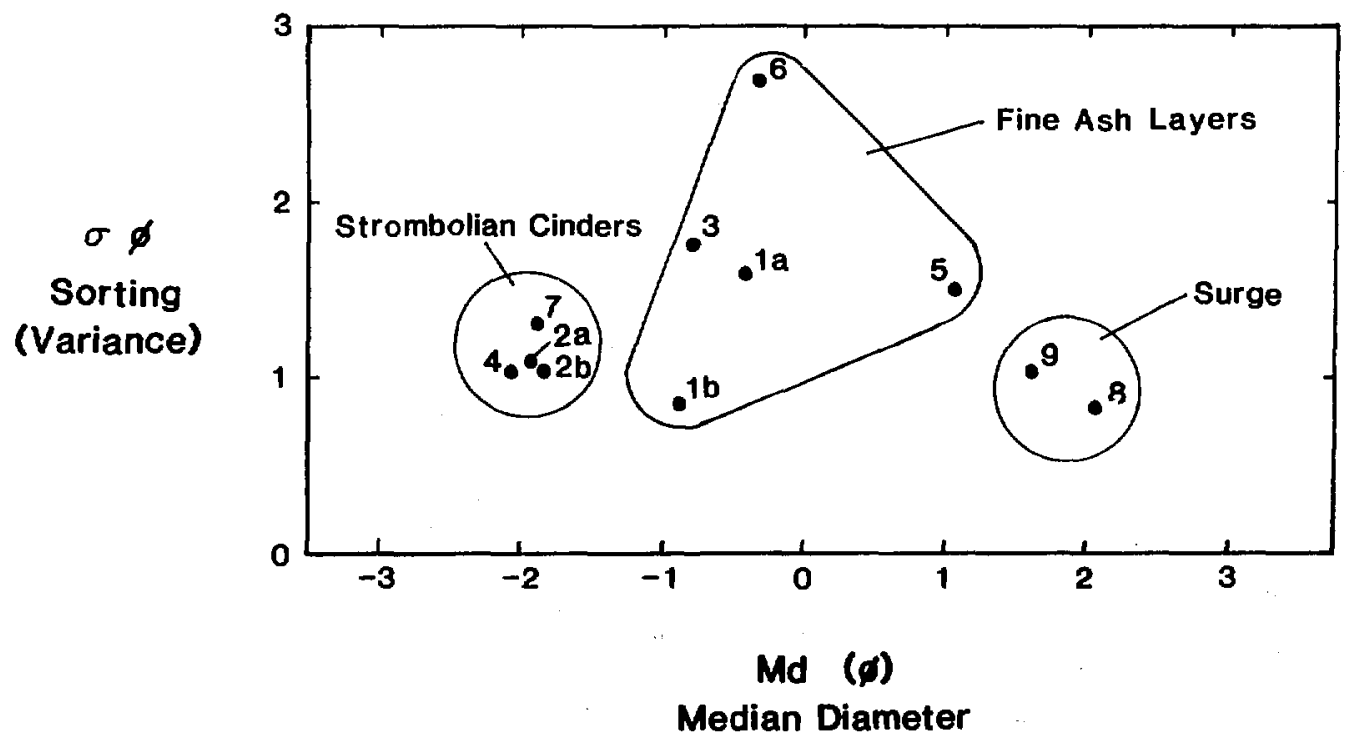

F1g. 14. Plot of Inman 50 sorting coefficient vs median diameter showe the plotted fields of scoria, fine ash, and surge samples. 
Figure 15 is a plot of $\mathrm{Md}_{\phi}$ and wt\% ash finer than $1.0 \mathrm{~mm}$ vs the stratigraphic sequence of samples. In this and subsequent plots, values are welghted by the thickness of the sampled interval. Hence, samples from thin stratigraphic intervals have values plotted as spikes and show sharp discontinuities in the overell character.

2. Constituent Analysis. The basaltic tephra of Lathrop Wells consists of basaltic glass fragments, crystal pieces, and lithic clasts from underlying rock units. The abundance of each of these constituents varies among samples and among the various size fractions within individual samples. The constituent abundances were obtained by grain counts done with a binocular microscope. Three size fractions were counted: 63 to 125,125 to 250, and 250 to $707 \mu \mathrm{m}$. Because of the large number of grains included in the field of microscopic view, accuracy is about $5 \%$ by volume for glass and crystal constituents and $\pm 0.1 \%$ by volume for lithic materials. Data are listed in Appendix F.

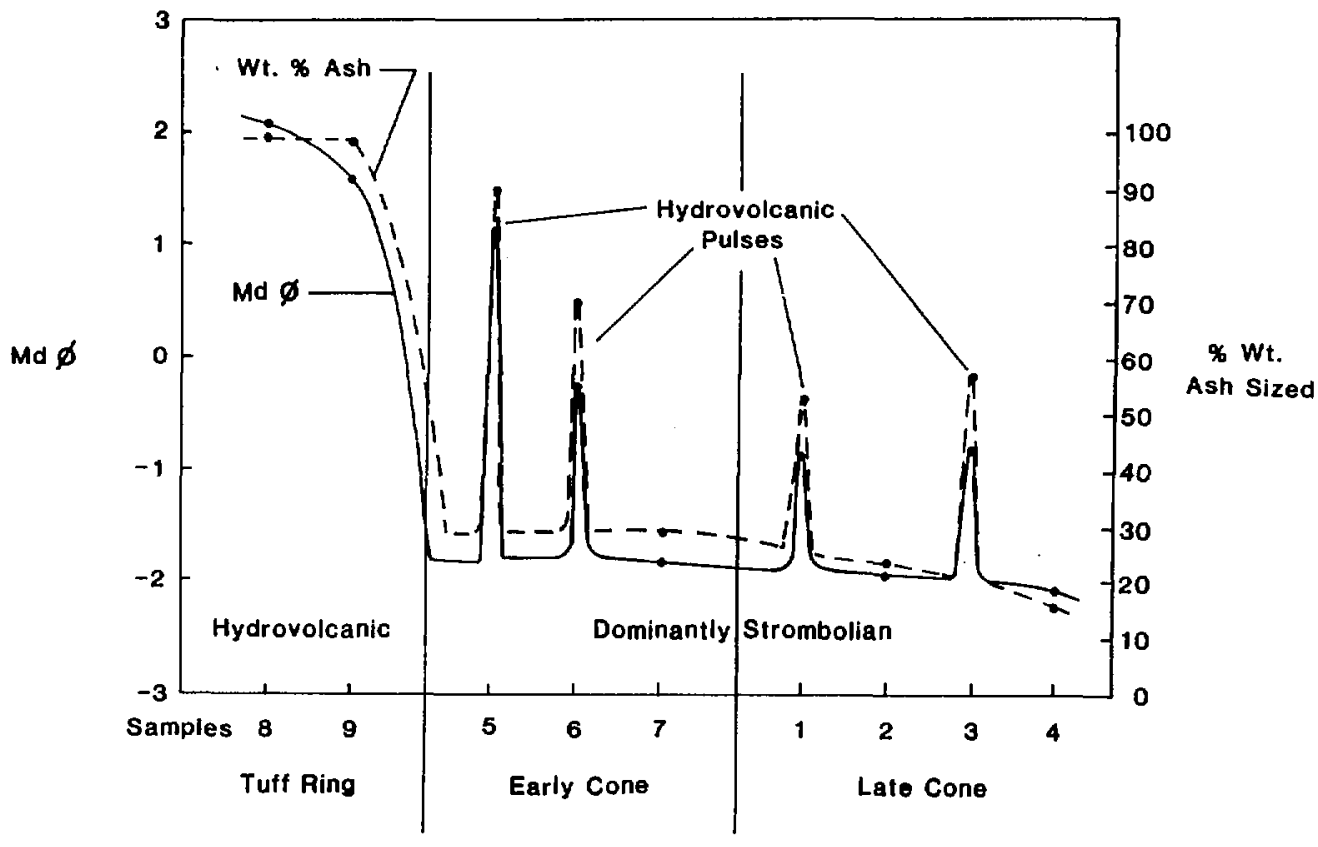

Fig. 15. Plot of median diameter and wt\% ash $(<1.0 \mathrm{~mm})$ vs stratigraphic position. 
Figure 16 is a plot of constituent abundance vs stratigraphy. This plot 1llustrates the variation of abundances for each of the three size fractions and the marked difference between surge' and fine ash samples and scoria samples.

Lithic constituents represent pleces of country rock broken and incorporated into the rising magma. This "mixing" occurs because of large hydraulic pressure gradients. Where groundwater moves into and contacts rising magma, thermal-hydraulic fracturing of the wall rock and magma occurs. Thus, the lithic type and abundance data indicate the stratigraphic level of hydrovolcanic interaction. For the Lathrop Wells tephra, tuffaceous fragments from the Tiva Canyon Member of the Paintbrush Tuff dominate lithic constituents. We conclude that groundwater interaction with magma occurred dominantly in this stratigraphic interval, which is estimated to be at, shallow depths.

3. Tephra Surface Textures. Following the method of Sheridan and Marshall $^{51}$ and that of Wohletz and Krinsely, ${ }^{52}$ we prepared samples for SEM inspection. Samples were split into a coarse fraction for low-resolution microscopy and a fine fraction $(<63 \mu \mathrm{m})$ for high-resolution imaging on the upper stage of the ISI model DS 130 SEM. The upper stage permitted adequate Imaging to magnifications of about $10^{5}$, which is necessary for particles in the size range of 0.1 to $1.0 \mu \mathrm{m}$. The technique for quantification of textural features is discussed by Wohletz and Krinsely ${ }^{52}$ and Wohletz. ${ }^{48}$

The presence or absence of five textural features was noted: vesicularity, blocky grain boundaries, fused surfaces, surface chemical alteration, and grain abrasion shown by overall rounding of initially sharp edges. Heiken ${ }^{46,47}$ noted that the blocky texture is a distinguishing characteristic of ash grains formed in hydrovolcanic eruptions. Vesicularity is a measure of both the completeness of volatile exsolution at low pressures just before eruption and the relative concentration of volatile species in the magma. Fused surfaces form on ash particles when fragmentation occurs before melt surface temperature has fallen below the solidification temperature. Alteration is the chemical response of ash particle surfaces to hot volatiles and fluids during eruption and to groundwater or surface water after tephra emplacement. At the Lathrop Wells basalt center, most alteration must have occurred during and shortly after eruption because of the abundance of vapor present in the eruption cloud. 


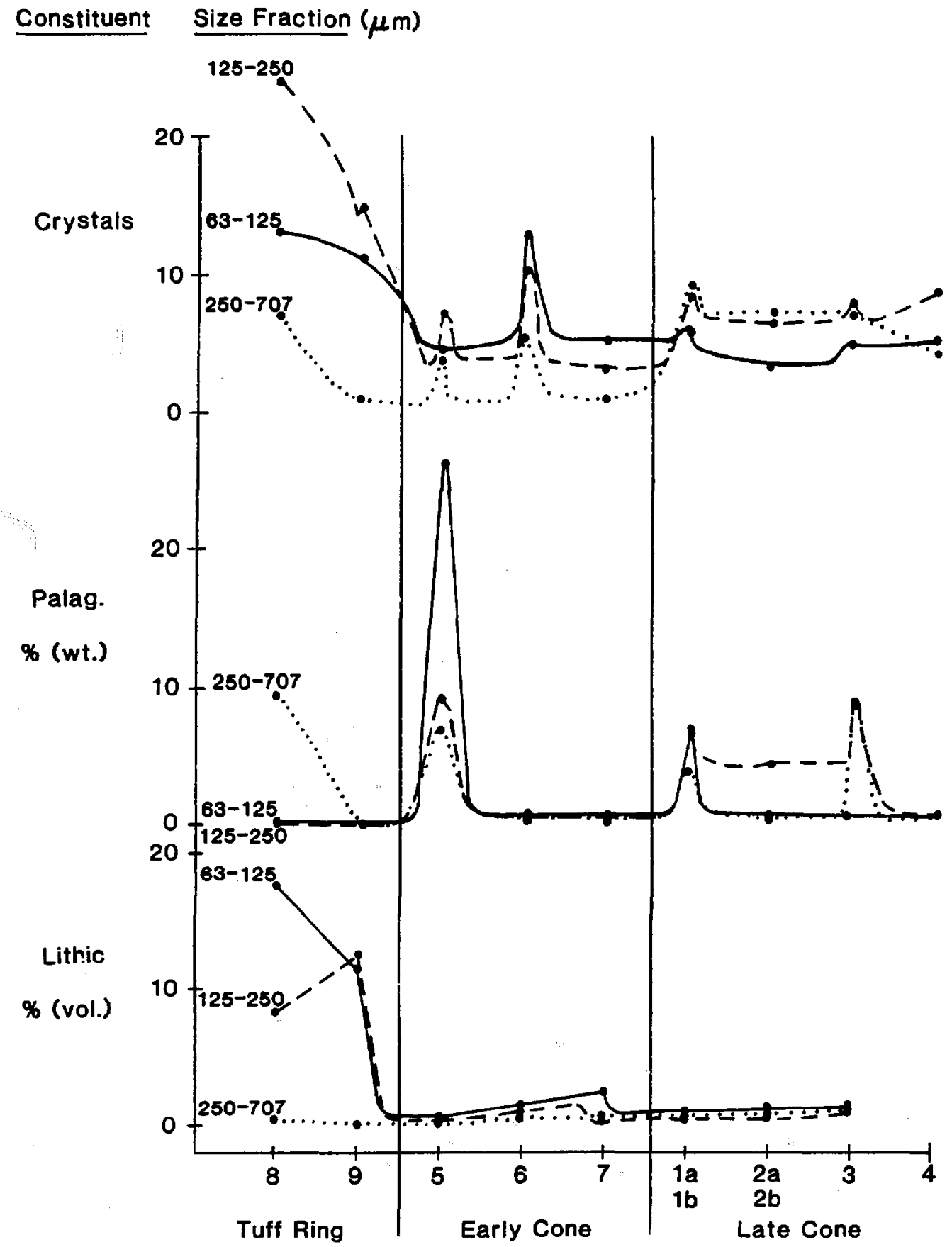

F1g. 16. Plot of tephra constituent abundances vs stratigraphic position. Palag: Palagonftized basaltic glass. 
Data for these 5 textural features were obtained by inspecting at least 50 representative grains for each sample and documentation by SEM Images. Abundances are listed in Appendix $G$ and shown in Fig. 17.

4. Surface Chemistry. As part of the SEM analysis, EDS analysis of grain surfaces was done to give a semiquantitative measure of grain surface alteration. The justification for quantitative analysis of particle surfaces using the peak-to-background method is described by Rez and Konopka. 53 They found that the peak-to-background ratio does not vary much with sample orientation. However, care was taken in this study to achieve uniform sample orlentation to allow correlation among grains analyzed.

For each sample, at least seven analyses were made and the results were averaged. Results are shown in Table IV and are compared to the average composition of Lathrop Wells lava reported by Vaniman et al. 5 Using the standard deviation of element abundances from the EDS technique, we achieved a reproducability of between \pm 0.1 to $4.6 \%$, depending upon the element analyzed (see Table IV). Figure 18 is a plot of elemental abundances vs stratigraphic position and shows the variation of surface alteration. Again, marked deviations in composition are noted for surge and fine ash samples but not for scoria samples, which show the least alteration from the fresh lava chemistry.

5. Interpretations. The tephra data presented in this section form the basis for detalled interpretation of the eruption mechanism of the Lathrop Wells basalt center. Plots showing tephra data plotted as a function of stratigraphy (Figs. 14 to 18) all show (1) a major discontinuity of plotted values at the transition from the earlier formed tuff ring to the scoria-cone-building eplsodes, (2) sharp spikes in plotted values corresponding to fine ash samples compared to scoria samples, and ( 3 ) near uniformity of plotted values for samples of the same bed form. This is clear evidence that at least two fragmentation mechanisms produced the tephra.

The fact that scoria samples all show relatively high vesicularity, minor alteration by erupted vapors, few blocky breakage surfaces, and >2-mm particle sizes is best explained by an eruption wechanism in which rising magma is torn apart by expanding gas vesicles as it approaches the surface. Although there is no unequivocal data supporting the origin of the gas, the fact that the tephra show no quenching effects, no alteration caused by disequilibrium of the liquid phase (glase) or vapor pockets, and no 


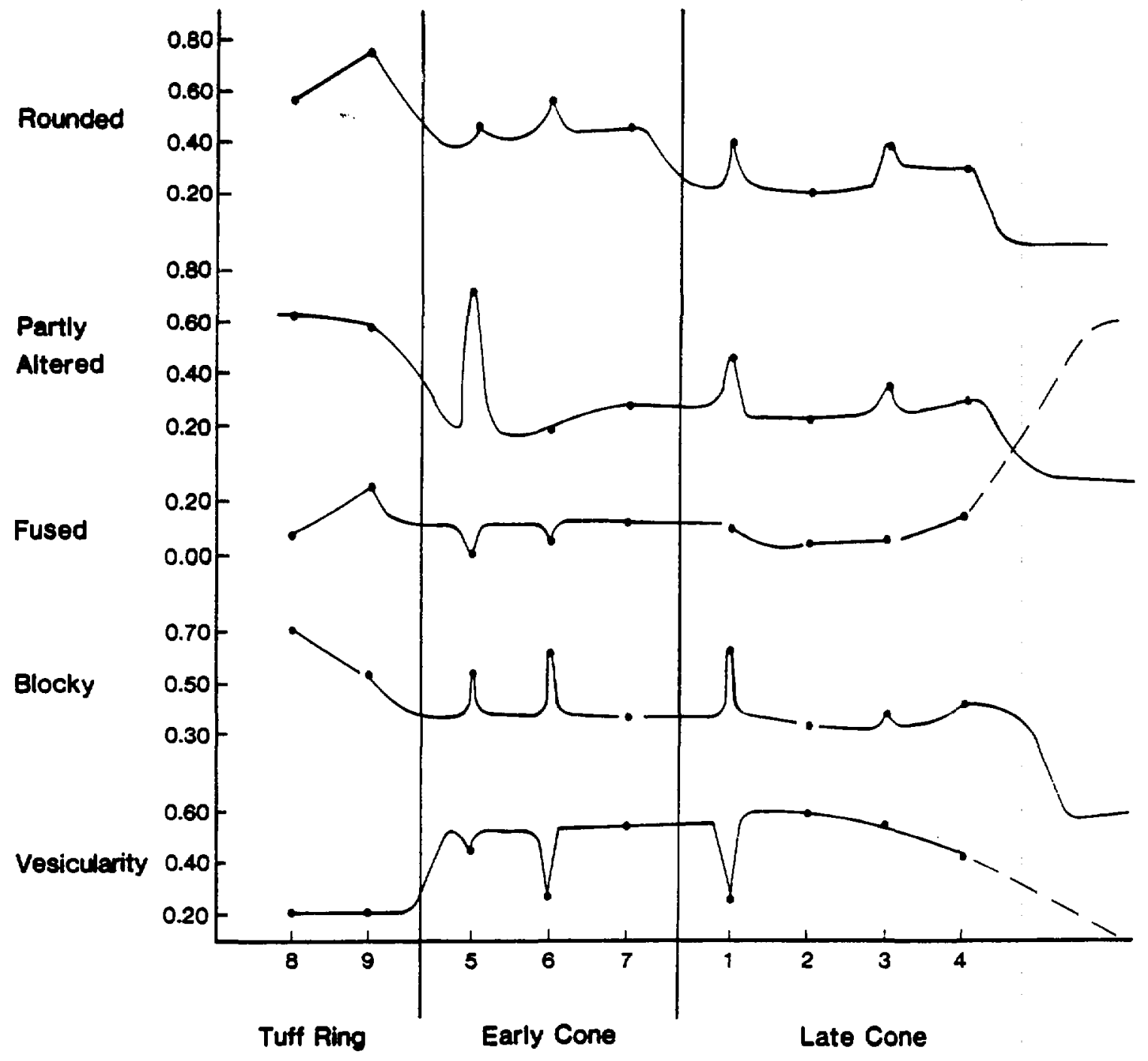

Fig. 17. Plot showing abundances of tephra textural features vs strat:graphic position. 
TABLE IV

SURFACE CHEMISTRY FOR LATHROP WELLS TEPHRA ${ }^{a}$

\begin{tabular}{|c|c|c|c|c|c|c|}
\hline & & Fine & Ash & Red & coria & Fine Ash \\
\hline & Lava & $1 a$ & $1 \mathrm{~b}$ & $2 a$ & $2 \mathrm{~b}$ & 3 \\
\hline $\mathrm{SiO}_{2}$ & 49.0 & ${ }^{50.66}$ & $\begin{array}{l}50.67 \\
(50)\end{array}$ & $\begin{array}{l}49.52 \\
(50)\end{array}$ & $\begin{array}{l}48.94 \\
(50)\end{array}$ & $\begin{array}{l}51.91 \\
(52)\end{array}$ \\
\hline $\mathrm{TiO}_{2}$ & 1.8 & $\frac{3.09}{(3)^{-}}$ & $(2)^{2.38}$ & $(3.52$ & $(3)^{2.71}$ & $\begin{array}{l}2.67 \\
(3)\end{array}$ \\
\hline $\mathrm{Al}_{2} \mathrm{O}_{3}$ & 16.5 & ${ }^{18.61}$ & $\begin{array}{l}14.20 \\
(15)\end{array}$ & $(12.50$ & ${ }_{(12)}^{12.85}$ & $\begin{array}{l}14.41 \\
(15)^{-}\end{array}$ \\
\hline $\mathrm{FeO}^{\mathrm{b}}$ & 10.7 & $\begin{array}{l}10.99 \\
(10)^{-1}\end{array}$ & $\begin{array}{l}14.99 \\
(15)^{2}\end{array}$ & $\begin{array}{l}19.34 \\
(20)\end{array}$ & $\begin{array}{l}16.69 \\
(15)\end{array}$ & $\begin{array}{l}10.73 \\
(10)\end{array}$ \\
\hline Mg0 & 5.9 & $\begin{array}{l}3.53 \\
(4)\end{array}$ & $\begin{array}{l}5.61 \\
(6)\end{array}$ & $\begin{array}{l}5.94 \\
(6)\end{array}$ & $\begin{array}{l}6.21 \\
(6)\end{array}$ & $\begin{array}{l}2.51 \\
(3)\end{array}$ \\
\hline $\mathrm{CaC}$ & 8.9 & $\begin{array}{l}6.54 \\
(6)^{-}\end{array}$ & $\begin{array}{l}5.71 \\
(6)\end{array}$ & $\begin{array}{l}3.73 \\
(3)\end{array}$ & $\begin{array}{l}7.12 \\
(6)\end{array}$ & $\begin{array}{l}10.20 \\
(9)\end{array}$ \\
\hline $\mathrm{Na}_{2} \mathrm{O}$ & 3.6 & $\begin{array}{c}3.24 \\
(3.25)\end{array}$ & $\begin{array}{c}3.17 \\
(3.25)\end{array}$ & $\begin{array}{c}3.10 \\
(3.00)\end{array}$ & $\begin{array}{c}2.80 \\
(2.75)\end{array}$ & $\begin{array}{c}0.42 \\
(0.50)\end{array}$ \\
\hline $\mathrm{K}_{2} \mathrm{O}$ & 1.76 & $\begin{array}{c}2.10 \\
(2.25)\end{array}$ & $\begin{array}{c}2.87 \\
(3.00)\end{array}$ & $\begin{array}{c}2.96 \\
(3.00)\end{array}$ & $\begin{array}{c}2.33 \\
(2.25)\end{array}$ & $\begin{array}{c}2.52 \\
(2.25)\end{array}$ \\
\hline MnO & 0.16 & $\begin{array}{c}0.17 \\
(0.20) \\
\end{array}$ & $\begin{array}{r}0.30 \\
(0.30) \\
\end{array}$ & $\begin{array}{r}0.38 \\
(0.40) \\
\end{array}$ & $\begin{array}{r}0.32 \\
(0.30) \\
\end{array}$ & $\begin{array}{r}0.30 \\
(0.30) \\
\end{array}$ \\
\hline Total & 99.42 & $\begin{array}{c}98.93 \\
(96.70)\end{array}$ & $\begin{array}{c}99.90 \\
(100.55)\end{array}$ & $\begin{array}{c}99.99 \\
(100.40)\end{array}$ & $\begin{array}{c}99.97 \\
(97.30)\end{array}$ & $\begin{array}{c}99.96 \\
(95.05)\end{array}$ \\
\hline Accuracy & $(\simeq)$ & 3.29 & 0.95 & 1.20 & 1.85 & 2.20 \\
\hline
\end{tabular}

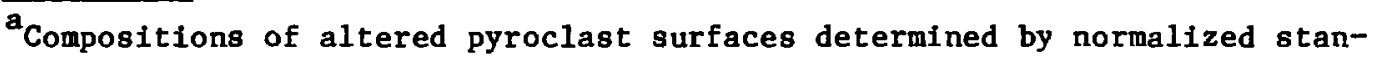
darless EDS analysis, except for that of the lava, which is averaged from several XRF analyses. Values shown in parentheses are rounded within error amount determined for each element as $\mathrm{SiO}_{2} \pm 2.16, \mathrm{TiO}_{2} \pm 0.96, \mathrm{Al}_{2} \mathrm{O}_{3} \pm$ $3.25, \mathrm{FeO} \pm 4.60, \mathrm{MgO} \pm 1.23, \mathrm{CaO} \pm 3.12, \mathrm{Na}_{2} \mathrm{O} \pm 0.27, \mathrm{~K}_{2} \mathrm{O} \pm 0.76$, and MnO \pm 0.11 . beO is expressed as total $\mathrm{FeO}+\mathrm{Fe}_{2} \mathrm{O}_{3} ;$ high values were caused by iron oxide
gtain on pyroclast surfaces. 
TABLE IV (cont)

\begin{tabular}{|c|c|c|c|c|c|c|}
\hline \multicolumn{2}{|c|}{$\begin{array}{c}\text { Gray } \\
\text { Scoria }\end{array}$} & \multicolumn{2}{|c|}{ Fine Ash } & \multirow{2}{*}{$\begin{array}{c}\begin{array}{c}\text { Gray } \\
\text { Scoria }\end{array} \\
7\end{array}$} & \multicolumn{2}{|c|}{ Surge Ash } \\
\hline & 4 & 5 & 6 & & 8 & 9 \\
\hline $\mathrm{SiO}_{2}$ & $\begin{array}{l}49.85 \\
(50)\end{array}$ & $\begin{array}{l}54.59 \\
(54)\end{array}$ & $\begin{array}{l}55.61 \\
(56)\end{array}$ & $\begin{array}{l}50.98 \\
(50)\end{array}$ & $\begin{array}{l}55.04 \\
(56)\end{array}$ & $\begin{array}{l}56.39 \\
(56)\end{array}$ \\
\hline $\mathrm{TiO}_{2}$ & $(5.51$ & $\left(^{2.49}\right.$ & $(3)^{2.56}$ & $(3.32$ & ${ }_{(3)}^{2.61}$ & $\begin{array}{l}2.04 \\
(2)\end{array}$ \\
\hline $\mathrm{Al}_{2} \mathrm{O}_{3}$ & $\begin{array}{l}10.77 \\
(12)\end{array}$ & $\begin{array}{l}14.85 \\
(15)\end{array}$ & $\begin{array}{l}14.98 \\
(15)^{-}\end{array}$ & $\frac{11.37}{(12)}$ & $\begin{array}{l}14.14 \\
(15)\end{array}$ & $\begin{array}{l}13.86 \\
(15)^{-}\end{array}$ \\
\hline $\mathrm{FeO}^{\mathrm{b}}$ & $\begin{array}{l}19.38 \\
(20)\end{array}$ & $\begin{array}{l}15.12 \\
(15)\end{array}$ & $\begin{array}{l}13.25 \\
(15)\end{array}$ & $\begin{array}{l}19.30 \\
(20)\end{array}$ & $\begin{array}{l}14.90 \\
(15)\end{array}$ & $\begin{array}{l}15.97 \\
(15)\end{array}$ \\
\hline $\mathrm{MgO}$ & $(3.14$ & $\begin{array}{l}4.04 \\
(4)\end{array}$ & $(2)^{1.55}$ & ${ }_{(3)}^{2.53}$ & ${ }^{2.30}$ & $\begin{array}{l}2.50 \\
(2)\end{array}$ \\
\hline $\mathrm{CaO}$ & $\begin{array}{l}8.65 \\
(9)\end{array}$ & $\begin{array}{l}8.40 \\
(9)\end{array}$ & $\begin{array}{l}8.98 \\
(9)\end{array}$ & $\begin{array}{l}9.01 \\
(9)\end{array}$ & $\begin{array}{l}8.17 \\
(9)\end{array}$ & $\begin{array}{l}6.55 \\
(6)\end{array}$ \\
\hline $\mathrm{Na}_{2} \mathrm{O}$ & $\begin{array}{c}0.57 \\
(0.50)\end{array}$ & $\begin{array}{r}0.09 \\
(0.0)\end{array}$ & $\begin{array}{c}0.24 \\
(0.25)\end{array}$ & $\begin{array}{c}0.27 \\
(0.25)\end{array}$ & $\begin{array}{c}0.0 \\
(0.0)\end{array}$ & $\begin{array}{c}0.0 \\
(0.0)\end{array}$ \\
\hline $\mathrm{K}_{2} \mathrm{O}$ & $\begin{array}{c}2.63 \\
(3.00)\end{array}$ & $\begin{array}{c}2.20 \\
(2.25)\end{array}$ & $\begin{array}{c}2.43 \\
(2.25)\end{array}$ & $\begin{array}{c}3.03 \\
(3.00)\end{array}$ & $\begin{array}{c}2.80 \\
(3.00)\end{array}$ & $\begin{array}{c}2.62 \\
(3.00)\end{array}$ \\
\hline Mno & $\begin{array}{c}0.44 \\
(0.44) \\
\end{array}$ & $\begin{array}{c}0.18 \\
(0.20) \\
\end{array}$ & $\begin{array}{r}0.20 \\
(0.20) \\
\end{array}$ & $\begin{array}{c}0.27 \\
(0.30) \\
\end{array}$ & $\begin{array}{c}0.0 \\
(0.0) \\
\end{array}$ & $\begin{array}{c}0.0 \\
(0.0) \\
\end{array}$ \\
\hline Total & $\begin{array}{c}99.94 \\
(101.90) \\
\pm 1.84\end{array}$ & $\begin{array}{c}100.55 \\
(101.45) \\
1.56\end{array}$ & $\begin{array}{c}99.80 \\
(102.70) \\
1.88\end{array}$ & $\begin{array}{c}100.08 \\
(100.55) \\
1.31\end{array}$ & $\begin{array}{c}99.96 \\
(103.00) \\
1.92\end{array}$ & $\begin{array}{c}99.93 \\
(99.00) \\
0.96\end{array}$ \\
\hline
\end{tabular}

\footnotetext{
${ }^{a}$ Compositions of altered pyroclast surfaces determined by normalized standarless EDS analysis except, for that of the lava, which is averaged from several XRF analyses. Values shown in parentheses are rounded within error amount determinad for each element as $\mathrm{SiO}_{2} \pm 2.16, \mathrm{TiO}_{2} \pm 0.96, \mathrm{Al}_{2} \mathrm{O}_{3} \pm$ $3.25, \mathrm{FeO} \pm 4.60, \mathrm{MgO} \pm 1.23, \mathrm{CaO} \pm 3.12, \mathrm{Na}_{2} \mathrm{O} \pm 0.27, \mathrm{~K}_{2} \mathrm{O} \pm 0.76$, and Mno \pm 0.11 .

$\mathrm{b}_{\mathrm{FeO}}$ is expressed as total $\mathrm{FeO}+\mathrm{Fe}_{2} \mathrm{O}_{3}$; high values were caused by iron oxide stain on pyroclast surfaces.
} 
$\Lambda$ OR $\neg$ DENOTES HYDROVOLCANIC PULSE
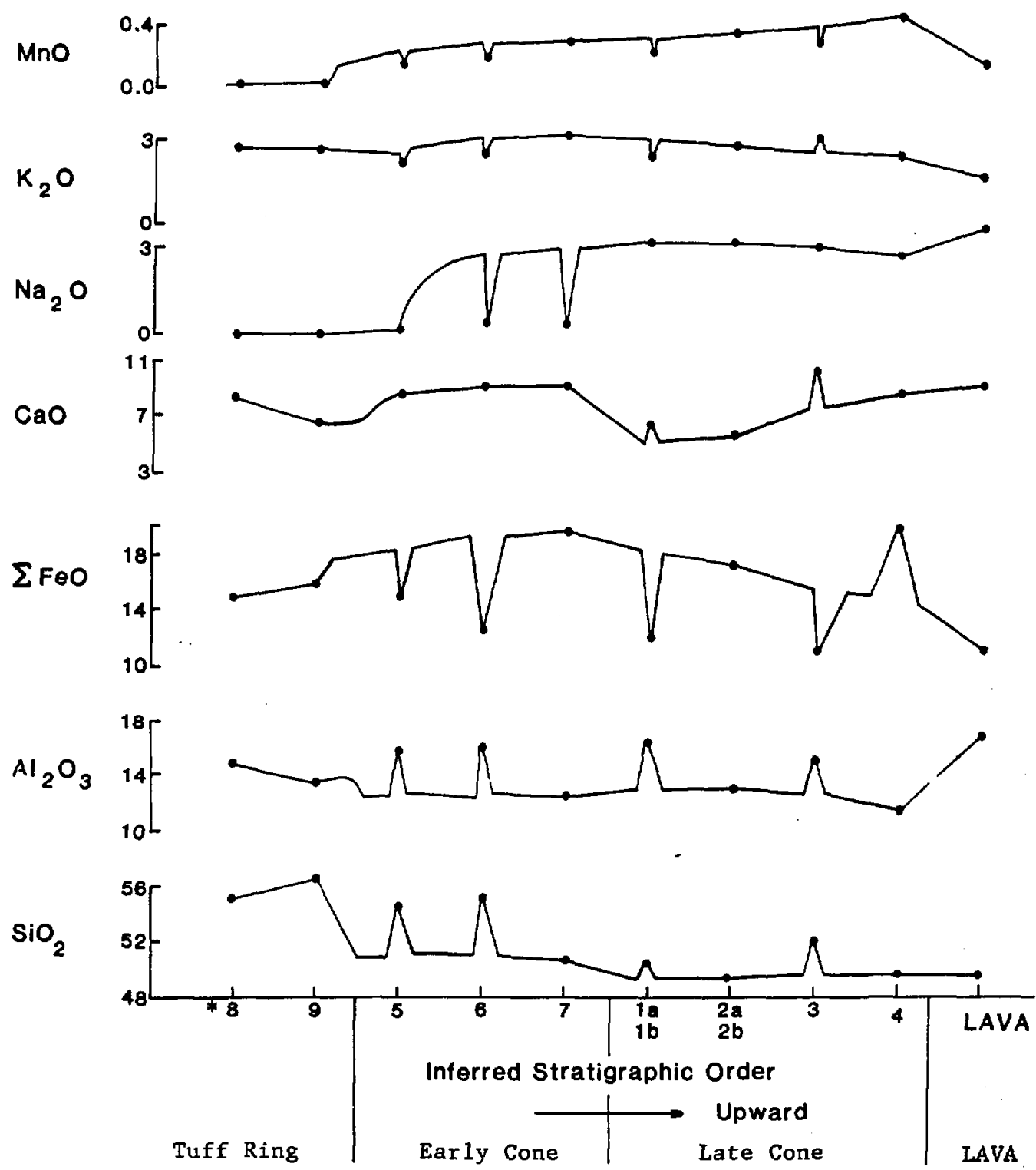

* $+8,9,5,6,1 \mathrm{a}, 1 \mathrm{~b}$ and 3 are hydrovolcanic samples

Fig. 18. Plot of chemical composition of tephra surfaces vs stratigraphic position. 
brittle fracture textures makes it likely that the vapors were originally dissolved in the melt. Basalt melts typically may contain up to several weight percent $\mathrm{H}_{2} \mathrm{O}$ in solution, which exsolves with decreasing pressure. This origin does not preclude a deep $(>1-$ to $10-\mathrm{km})$ external source of water that may have passively diffused into the melt from country rock.

Pyroclastic surge, fine ash samples, and scoria samples, show distinctly different textures and surface chemical compositions. Blocky particle surfaces, surface chemical alterations, fine grain size ( $<1 \mathrm{~mm})$, and low vesicularity indicate that these tephra were not formed by exsolving volatile components, but by a process that mechanically fractured the magma, quenched it, and produced surface chemical changes by disequilibrium conditions. This type of tephra formation is best explained by a hydrovolcanic mechanism.

Opening eruptions at Lathrop Wells were hydrovolcanic (also termed phreatomagmatic or Surtseyan after the explosive oceanic eruptions of the volcano Surtsey). These eruptions produced uniformly fine-grained $(<500-\mu \mathrm{m})$ ash that was dispersed in turbulent, ground-hugging, density flows. The phenomenon is analogous to the base surge formed by large, near-surface chemical and nuclear detonations, and it is called pyroclastic surge in volcanic nomenclature. Concurrent with surge deposition, much of the fine ash was probably injected into the atmosphere and carried by winds for several tens of kilometers. Wohletz ${ }^{49}$ showed that particle size in hydroexplosions decreases with increasing violence of vapor explosions because the melt surface area controls the heat transfer rate. Accordingly, the thermodynamic efficiency of these explosions for the Lathrop wells deposits is estimated to have been 1 to $5 \%$. This means that 1 to $5 \%$ of the total thermal energy of the erupted basalt was converted to kinetic energy of dispersal. Basalt has a heat content of about $1 \times 10^{3} \mathrm{~J} / \mathrm{g}\left(1 \times 10^{10} \mathrm{erg} / \mathrm{g}\right)$ at magma temperatures near $1100^{\circ} \mathrm{C}$. Assuming a surge deposit volume of about $0.01 \mathrm{~km}^{3}$ and a bulk density of $1.5 \times 10^{3} \mathrm{~kg} / \mathrm{m}^{3}$, the eruption released 1 to $5 \times 10^{14} \mathrm{~J}$ of energy. This is roughly analogous to the energy released from 35 to $180 \mathrm{kt}$ of high explosives.

C. Crater Dimensions: Hydrovolcanic Centers

The worst case scenario for intrusion of a repository by basalt magma is exhumation of the repository by crater-forming hydrovolcanic explosions--a situation that would vastly increase the amount of a waste inventory that 
could be dispersed by an eruption. The possibility of this scenario can be tested by crater dimension data for known hydrovolcanic craters. If a hydrovolcanic eruptive cycle were to exhume a waste repository, the maximum crater depth would have to equal the burial depth of the repository. Figure 19 is a relative-frequency plot of crater depth for known hydrovolcanic craters, mars, and tuff rings (data from Plke and $\mathrm{Clow}$ ). 54 The crater-depth data are positively skewed with a mean of $91 \pm 67 \mathrm{~m}$. The depth to a repository in the lower devitrified zone of the Topopah Spring Member varies through the exploration block. A representative depth of about $380 \mathrm{~m}$ can be used, based on the depth to the target horizon in Drill Hole USW G-4. This depth is over 4 std. dev. from the mean crater depth for hydrovolcanic craters and exceeds the maximum crater depth in the data catalog of Pike and Clow. 54

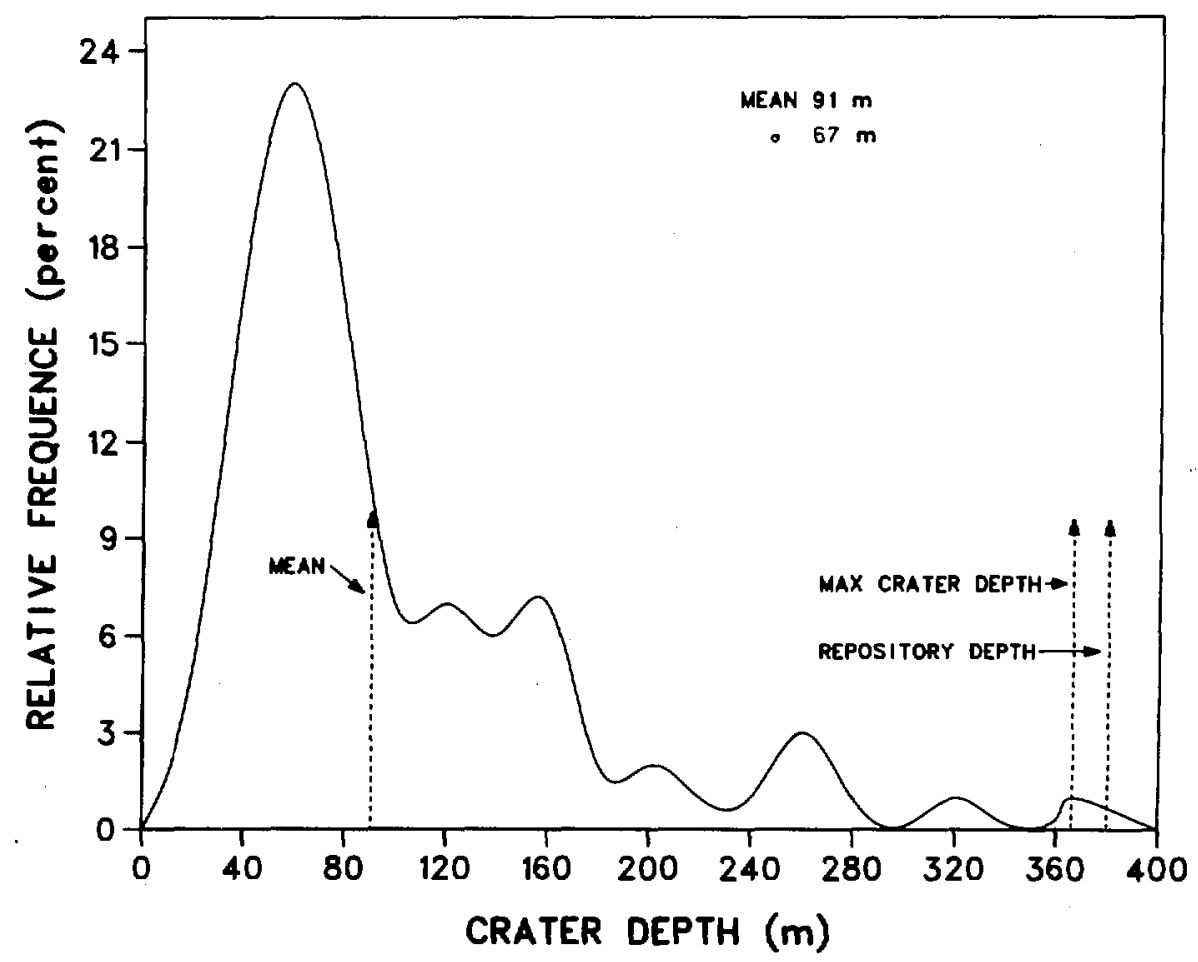

Fig. 19. Relative-frequency diagram of crater depth for hydrovolcanic craters. Repository depth is the estimated average depth to the repository horizon at Yucca Mountaln. Maximum crater depth is taken from the deepest measured crater. Data on crater depths are from Pike and Clow. 54 
The low probability of repository disruption coupled with the low probability of a repository being exhumed by hydrovolcanic explosive cratering suggests that this worst case scenario is of little concern at Yucca Mountain.

\section{Depth and Energy of Explosive Magma/Water Interactions}

A large number of experiments on FCIs have been published over the last 15 years (for example, Sandia Laboratories, ${ }^{55}$ Buxton and Benedict, 56 Corradini, ${ }^{57}$ Froehlich et al., 58 and Dullforce et al. ${ }^{59}$ ). Most of these studies are concerned with experiments in which molten metals contact water. Melts of iron oxide and aluminum (thermite) have commonly been used. Thermite has physical properties that are analogous to those of basalt (Wohletz and McQueen ${ }^{43}$ ), which allows FCI experiments that simulate a volcanic eruption. This work (Sheridan and Wohletz ${ }^{42,37}$ and Wohletz ${ }^{49}$ ) has led to a general understanding of hydrovolcanic explosions.

Experiments show that there are several important physical parameters that control the interaction between a basalt-like melt and water, including (1) water-to-melt mass ratio, (2) confining pressure, and (3) contact geometry. Figures 20 and 21 illustrate the mass ratio and particle-size effects upon thermodynamic efficiency, which determines the energy of the eruption. A sharp transition from Strombolian to Surtseyan eruption occurs at mass ratios around 0.2. This transition 1 s concurrent with an increase in the kinetic-to-thermal-energy ratio that can be qualitatively described as a transition from lava fountaining to dynamic vapor explosions. Also, the size of magma fragments decreases and the ash dispersal area greatly increases during this explosive transition. The contact geometry is closely related to the mass ratio and effectively determines the initial surface area involved during heat transfer. A limited area of contact, such as a dike projecting through a thin $(<10-m)$ aquifer, does not allow development of explosive instability, whereas contact with a standing body of water or thick (>30-m) horizon of water-saturated rock permits water to vaporize at explosive rates. The effect of pressure is complex and is discussed in more detail below.

Vents that show explosive hydrovolcanic activity form common volcanic landforms classified as mars, tuff rings, and tuff cones (Sheridan and Wohletz ${ }^{37}$ ). The dimensions of these volcanoes demonstrate that magma/water mixing and explosion generally occur at depths less than $200 \mathrm{~m}$, which corresponds to $5 \mathrm{MPa}$ ( $\approx 50$ bars) or less. Only recently has it been discovered that 


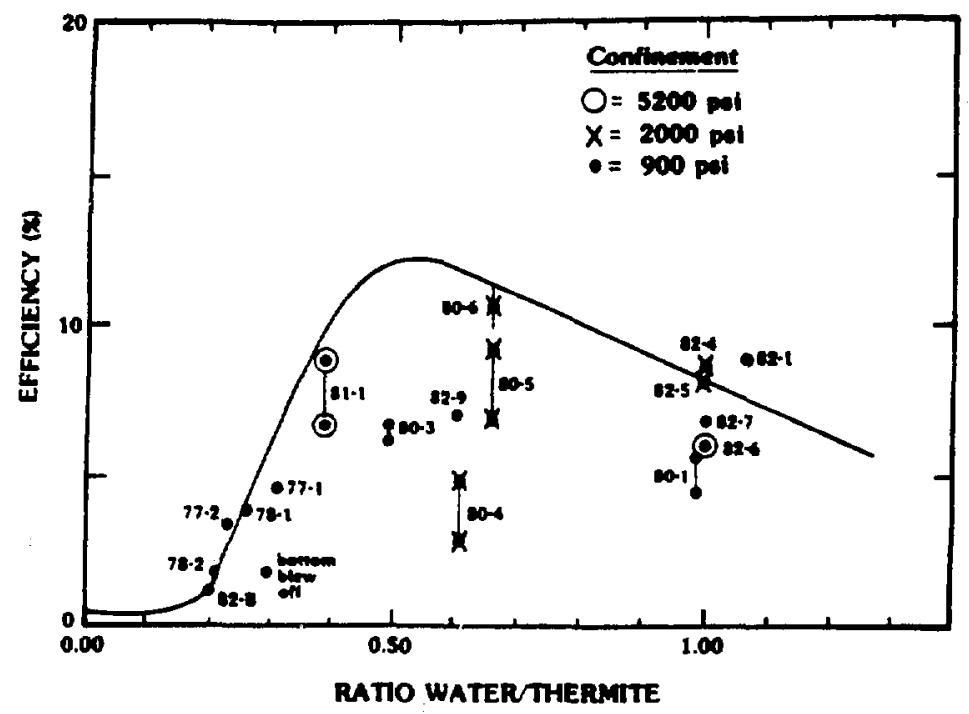

Fig. 20. Plot of thermodynamic efficiency (kinetic energy/thermal energy) vs water-to-melt-mạs ratio for thermite/water volcano experiments.37

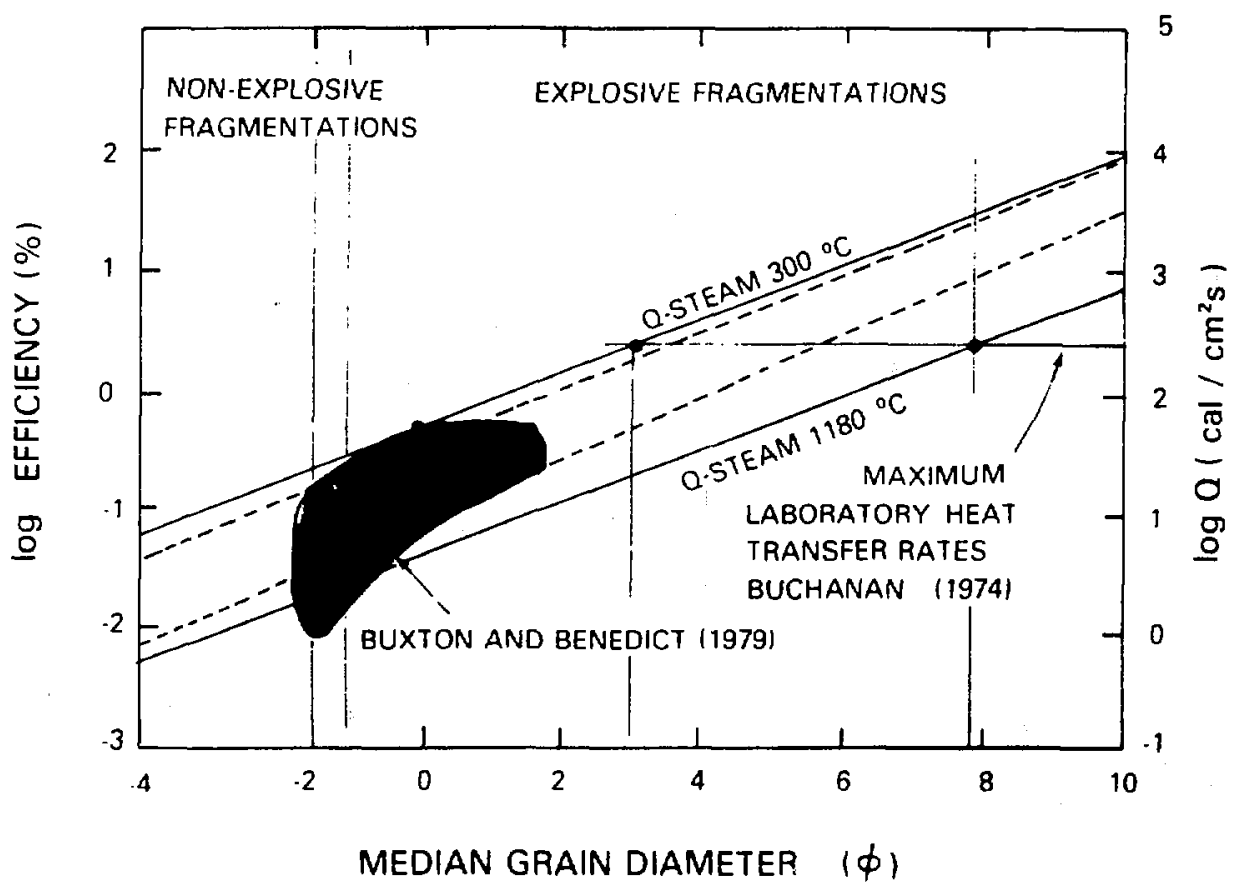

Fig. 21. Plot of thermodynamic efficiency vs median grain size of fuel/coolant interaction. ${ }^{49}$ 
deeper aquifers contribute to hydroexplosions; this was documented at Mount Vesuvius, Italy, where hydrovolcanic deposits contain lithic clasts from the major aquifer [at a depth of $5 \mathrm{~km}(\approx 120 \mathrm{MPa})] \bullet^{44}$ As we will discuss later, deep interaction at confining pressures above the critical point of water probably involves a different explosive mechanism.

Sheridan and Wohletz ${ }^{37}$ conducted volcano experiments at confining pressure from $\approx 0$ to $35 \mathrm{MPa}$ and noted explosive results over the entire experiment range. The results of experiments in progress appear to show that with increasing pressure (at the most explosive mass ratios), the probability of explosive interaction decreases from nearly 1.00 at $7 \mathrm{MPa}$ to less than 0.5 at $35 \mathrm{MPa}$; however, the explosive efficiency increases as much as twofold with increasing pressure in this range. This work is augmented by other experimental investigations at smaller scales, which demonstrate pressure effects. Nelson and Buxton ${ }^{60}$ suggest that single-drop (1-g) experiments have a pressure threshold of 0.5 to $0.8 \mathrm{MPa}$, above which explosions are suppressed. Sturtevant and Frost ${ }^{61}$ measured a steady decrease in explosive probability up to $0.07 \mathrm{MPa}$ for analogous systems of butane, which they also predicted from the theory of Landau instability. These measured pressure thresholds are very dependent upon a trigger mechanism, which is generally a small exploding bridge wire (1- to 10-MPa pulse); an analogous trigger in a volcanic setting may be an earthquake. After an explosion begins, pressures greater than $150 \mathrm{MPa}$ may be generated.

\section{E. Models for Water/Melt Interaction}

Two types of theoretical models have evolved that explain explosions occurring during contact between a hot fluid and a cold one: spontaneous nucleation-pressure suppression and thermal detonation. Both models require that upon contact, a period of stable film bolling serves to insulate the molten fuel from the coolant and gradually causes the fuel to fragment and mix with the coolant. With increased heat transfer caused by mixing, rapid vaporization can occur if (1) the coolant is superheated to the temperature of spontaneous vapor bubble nucleation or (2) mixing of the fuel and coolant is further enhanced by an external pressure wave (trigger), which, when of sufficient magnitude, causes the insulating filin barriers to collapse and allows rapid heat transfer and vapor production in its wake (this is often referred to as a detonation wave). 
The superheat limit case requires that the contact temperature $\left(T_{I}\right)$ be above the spontaneous nucleation temperature $\left(T_{S N}\right)$ of the coolant:

$$
\mathrm{T}_{\mathbf{I}}>\mathrm{T}_{\mathrm{SN}},
$$

where

$$
T_{I}=\frac{T_{H}\left[k /(a)^{1 / 2}\right]_{H}+T_{C}\left[k /(a)^{1 / 2}\right]_{C}}{\left[k /(a)^{1 / 2}\right]_{H}+\left[k /(a)^{1 / 2}\right]_{C}},
$$

$T=$ temperature, $k=$ thermal conductivity, $a=$ thermal diffusivity that is approximated as $\mathrm{k} / \mathrm{C}_{\mathrm{v}}\left(\mathrm{C}_{\mathrm{v}}=\right.$ heat capacity at constant volume), $\mathrm{H}=$ hot material, and $C=\operatorname{cold}$ material. For basalt at $1200^{\circ} \mathrm{C}, k_{H}=5 \times 10^{-3}$ $\mathrm{cal} / \mathrm{cm}-\mathrm{s}-\mathrm{k}$, and for water at $25^{\circ} \mathrm{C}, \mathrm{k}_{\mathrm{C}}=3.7 \times 10^{-5} \mathrm{cal} / \mathrm{cm}-\mathrm{s}-\mathrm{k} ;\left[\mathrm{k} /(\mathrm{a})^{1 / 2}\right]$ is about 0.09 for the basalt and 0.61 for water. These conditions give $T_{I}$ at about $600^{\circ} \mathrm{C}$. The spontaneous nucleation teinperature 18 given by the rate equation

$$
J=A \exp (-W / s T)
$$

where $T_{S N}$ occurs at $T$ and satisfies the condition

$$
\cos (d J / d T) \simeq 0 \simeq \cos \left[A w / s T^{2} \exp (-W / s T)\right]
$$

For the rate equation $J=$ rate of bubble nucleation per unit area, $A$ is a constant characterlalrig the Ilquid, $s=$ Boltzmann's constant, and $W$ is the reversible work of bubble formation in the 1iquid, which is

$$
W=16 \pi \sigma^{3} / 3\left(P_{v}-P_{1}\right)^{2}
$$

where $\sigma=$ surface tension of the pure liquid, and $P_{v}$ and $P_{1}$ are the vapor and liquid pressures, respectively. The bubble work function is dependent upon the contact wetting angle, which is important for Impure liquids and results in somewhat lower values of $\mathrm{T}_{\mathrm{SN}}$. For water, the highest value of superheating attained in the laboratory is around $290^{\circ} \mathrm{C}$, but this value Increases with pressure towards the critical T of $374^{\circ} \mathrm{C}$ (Reloy ). 
For most experimental conditions $\mathrm{T}_{\mathrm{SN}} \approx 300^{\circ} \mathrm{C}$. Results for Eq. (2) show that the requirement of $\mathrm{Eq}$. (1) is easily met for the conditions of basalt/water contact.

Another aspect of pressure is that nucleation is suppressed with increasing pressure as is predicted by a form of the Rayleigh bubble growth equation

$$
\mathrm{dU} / \mathrm{dt}=\frac{1}{r}\left(\frac{\mathrm{P}_{f}-\mathrm{P}_{a m b}}{\rho}-\frac{3 \mathrm{U}^{2}}{2}\right),
$$

where the outward accleration of a bubble surface dU/dt depends upon the bubble radius $r$. Here, $P_{f}$ and $P_{a m b}$ are the vapor pressure and ambient pressure, respectively, and $\rho$ is the liquid density. Predictions based upon the above consideration put the pressure threshold for spontaneous nucleation at about 1.3 MPa (Henry and Miyazaki ${ }^{63}$ ). Above that pressure, superheating vapor explosions are supposed to be improbable. This limit is eqivalent to about 50 to $100 \mathrm{~m}$ depth for basalt/water interactions.

The drawback to the spontaneous nucleation-preasure suppression model is that it does not strictly fit experimental data at higher pressures. The scaling relationships for FCIs are as yet incompletely understood. A major consideration is that scale is critically important in determining the type of fluid Instability that may evolve at the fuel/coolant interface. Small (1- to $1000-\mathrm{g}$ ) interactions appear to be limited to superheating type of interaction (Taylor and Landau instabilities), whereas large ones may support a detonation type of interaction. This consideration has led other workers (for example, Board et al., ${ }^{64}$ Patel and Theofonous, ${ }^{65}$ and Condiff ${ }^{66}$ ) to consider another mechanism that may cause explosions in fuel/coolant systems at higher ambient pressures. This mechanism requires the assumption that fragmentation and intermixing between melt and water is not controlled by vapor bubble nucleation but relies upon the rapidly changing pressure-volume conditions existing across a shock wave moving through the melt/water mixture. In this model, an exturnally generated shock wave causes a differential acceleration of melt particles relative to the water. Using shock tube experiments on melt/water systems, Sharon and Bankoff 67 found that the acceleration caused the melt to break up into finer particles and that rapid thermal equilibration occurred in the expanding region behind the shock. 
If the vapor expansion caused by thermal equilibration of finely divided melt particles surrounded by water 18 great enough to produce particle velocities satisfying the Chapman-Jouguet (C-J) condition, the shock wave will be sustained. To meet the requirements of the $\mathrm{C}-\mathrm{J}$ condition, the melt breakup time $\left(t_{b}\right)$ must be shorter than that needed for velocity equilibration $\left(t_{v}\right)$. This requirement can be assessed by a function of the Bond number (Bo) of the melt/water system:

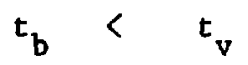

or

$$
t_{b} / t_{v}=\frac{3 \rho_{c} C_{d}(X)}{8 \rho_{f}\left(\rho_{f} / \rho_{c}\right)^{1 / 2}} 44 \mathrm{Bo}^{-1 / 4}<1 .
$$

This equation, derived by Fauske, ${ }^{68}$ has been modified in a manner similar to that suggested by Bankoff and $\mathrm{Jo}^{69}$ so that it includes the water-to-melt iass ratio effect $(X)$. The coefficient of drag $\left(C_{d}\right)$ on melt particles suspended in water has been assumed to be about 2 ; but Fauske ${ }^{68}$ showed that for numerous particles closely packed in a matrix of water, $C_{D}$ is more realistically about 68. In addition, $X$ is established to fit volcano experiments mentioned above:

$$
X \quad \therefore\left(0.0 I R_{\max } / R\right)[\exp (\Delta R)],
$$

where $R$ and $R_{\max }$ are the water-to-melt mass ratio and the optimum observed explosive ratios, respectively, and $\Delta R=$ the absolute value of $R_{\max }-R$ (Wohletz and McQueen ${ }^{43}$ ). Th1s requirement gives

$$
561 \text { (X) } \text { Bo }^{-1 / 4}<1
$$

for sustained detonation. Now the Bond number is $3 / 8$ the product of the coefficient of drag $\left(C_{D}\right)$ and the Weber number (a ratio of Inertial forces to surface tension forces) and is given as

$$
\text { Bo }=\frac{3 \rho_{c} U_{r e 1}^{2} r_{o} C_{d}}{8 \sigma} \text {, }
$$


where $\mathrm{U}_{\text {rel }}$ is the melt/water relative velocity caused by passage of the shock, $r_{0}$ is the initial melt particle radius, and $\sigma$ is the melt surface tension, which 18 about $0.5 \mathrm{~N} / \mathrm{m}$ for the volcano experiments. The $\mathrm{U}_{\text {rel }}$ is determined by mass and momentum conservation across the shock, assuming Rankine-Hugoniot conditions and knowledge of the initial $P$ and $V$ of the mixture and the $P$ and $V$ of the C-J state, which is the intersection of the Rayleigh line with the shock Hugoniot:

$$
U_{r e l}=\left[\left(P_{c j}-P_{i n i t}\right)\left(v_{i n i t}-v_{c j}\right)\right]^{1 / 2} .
$$

Board et al. ${ }^{64}$ estimated $U_{r e l} \simeq 100 \mathrm{~m} / \mathrm{s}$. Corradini ${ }^{57}$ estimated U as

$$
\mathrm{U}_{r e 1}=\left(P-P_{a m b}\right) / \rho_{c} c_{c}-\left(P-P_{a m b}\right) / \rho_{f} c_{f},
$$

where from volcano experiments $\rho_{c}=1 \times 10^{3} \mathrm{~kg} / \mathrm{m}^{3}, c_{c}=1.5 \times 10^{3} \mathrm{~m} / \mathrm{s}, \rho_{\mathrm{f}}=$ $4 \times 10^{3} \mathrm{~kg} / \mathrm{m}^{3}$, and $c_{f}=5 \times 10^{3} \mathrm{~m} / \mathrm{s}$. These conditions allow prediction of $U_{\text {rel }}$ at about $60 \mathrm{~m} / \mathrm{s}$ for satisfaction of the $\mathrm{C}-\mathrm{J}$ requirements of $100 \mathrm{MPa}$ for $P_{\text {amb }}=0.1 \mathrm{MPa}$. Increasing $\mathrm{P}_{\text {amb }}$ increases the value of pressure at the $\mathrm{C}-\mathrm{J}$ condition, which decreases the likelthood of attaining detonation. These values also agree with Drumheller's ${ }^{70}$ numerical calculations. If relative velocities produced are lower than about the $60 \mathrm{~m} / \mathrm{s}$ needed to sustain detonation, then the explosion will be quickly damped. Accordingly, a critical Bond number must be exceeded by the system to maintain a detonation where

$$
{ }_{\text {Brit }} / r_{0}=\frac{B o}{3 r X}\left[\left(P_{c j}-P_{a m b}\right) / P_{c j}\right]^{2} \text {, }
$$

as empirically determined from volcano experiments where $P_{c j} 18$ taken at $100 \mathrm{MPa}$. Thus, the mass ratio and ambient pressure effects have been included to fit experimental data and the relative velocity can be calculated as

$$
\mathrm{U}_{\mathrm{rel}}=\left(8 \sigma \mathrm{Bo}_{\mathrm{crit}} / 3 \rho_{\mathrm{c}} \mathrm{C}_{\mathrm{d}}\right)^{1 / 2}
$$


from the definition of Bo given in Eq. (11). The size of melt particles caused by the shock breakup is approximated from data as

$$
r_{1}=\left(8 \sigma / \rho_{c} U_{r e 1}^{2}\right) 100 \Delta R
$$

For various mass ratios, Table $V$ lists the calculated $U_{\text {rel }}$ and $r_{1}$; it also shows the threshold for detonation at ratios greater than 0.2 and less than or equal to about 4.0 , where $P_{a m b}=0.1 \mathrm{MPa}$. The limiting effect of increased ambient pressure also shown in Table $V$ indicates that detonating interaction is not likely to occur much above a $\mathrm{P}_{9 \mathrm{mb}}$ of $50 \mathrm{MPa}$ ( 500 bars). Without the mass ratio effect considered, Fauske ${ }^{9 \mathrm{mb}}$ argued that very large $r_{0}$ values $\left(r_{0}>10\right.$ in) are needed to satisfy the Bo crit of $10^{4}$ cited by Board et al. 64 and allow estimated $C-J$ conditions to exist in melt/water systems. We note here that irrespective of the mass ratio arguments shown above, volcanic systems can satisfy detonation requirements, whereas smaller, single-drop laboratory experiments do not.

\section{F. Discussion}

Data from crater depths of hydrovolcanic landforms given above indicate that confining pressure is an important limit to explosive water/magma interaction. However, it appears possible, based on the detonation model, that the intermixing of groundwater with magma can lead to explosions and that the actual depth of explosion is limited only by the strength of the surrounding country rock. For deep explosion $(7200 \mathrm{~m})$, a triggering agent is necessary, such as a strong earthquake or collapse of the vent overburden (for example, at Mount St. Helens in 1980).

Assuming the validity of the magma/water interaction models outlined above, a two-stage explosion sequence may be the best explanation for hydrovolcanic explosions where there is no obvious trigger. First, superheating (spontaneous nucleation vaporization) occurs at the top of the magma column 6 where ambient pressure is 1 ess than the suppression linit." In turn, this situation sets up strong stress waves that propagate down the vent and detonate the magna/water nixture at depth. 
TABLE V

EMPIRICAL DETONATION PARAMETERS FOR WATER/MELT INTERACTION ${ }^{a}$

$\mathbf{R}^{\mathbf{b}}$

$\left(\mathrm{H}_{2} \mathrm{O} / \mathrm{Melt}\right)$

Mase Rat1o

0.02

$P_{a=b}=1.0 \mathrm{MPa}(1$ bar)

Bo (crit)

$3.8 \times 10^{7}$

0.1
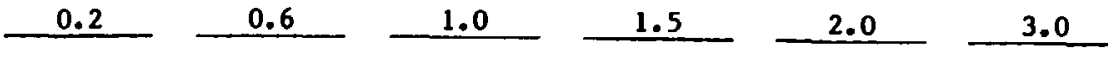

5.0

$u_{\text {rel }}(\mathbf{m} / \mathrm{s})$

$8.1 \times 10^{7} \quad 1.8 \times 10^{8} 6.5 \times 10^{8}$

$7.3 \times 10^{8}$

$6.6 \times 10^{8}$

$5.4 \times 10^{8}$

$1.4 \times 10^{8}$

$6.6 \times 10^{7}$

$r_{1}$ (u=)

240

$40 \quad 59$

113

120

114

103

75

36

3.114

31

56

178

1390

$P_{a=b}=20 \mathrm{MPa}$

${ }^{B o}$ (crit)

$U_{\text {rel }}(\mathrm{a} / \mathrm{s})$

$r_{1}(\mu \omega)$

$2.4 \times 10^{7}$

22

371
$5.2 \times 10^{7}$
32
156
$1.2 \times 10^{8}$
47
54
$4.2 \times 10^{8}$
90
5
$4.7 \times 10^{8}$

96
22
$4.2 \times 10^{8}$
91
48

$3.5 \times 10^{8}$

82

$8.9 \times 10^{7}$

60

$4.2 \times 10^{7}$

89

278

28

2295

$P_{a n b}=45 \mathrm{MPa}$

Bo (crit)

$u_{\text {rel }}(a / s)$

$1.1 \times 10^{7}$

$2.4 \times 10^{7}$

$5.4 \times 10^{7}$

$1.9 \times 10^{8}$

$2.0 \times 10^{8}$

$2.0 \times 10^{8}$

$1.6 \times 10^{8}$

$4.2 \times 10^{7}$

$2.0 \times 10^{7}$

800

331

117

62

66

63

57

101

185

42

595

20

4500

$P_{a=b}=50 \mathrm{MPa}$

${ }^{B 0}$ (crit)

$U_{\text {rel }}(\mathrm{E} / \mathrm{s})$

$r_{1}(\mu)$

$$
9.5 \times 10^{6}
$$

$$
2.0 \times 10^{7}
$$

$4.5 \times 10^{7}$

$1.6 \times 10^{8}$

16

24

208

45

20
$1.7 \times 10^{7}$
46
189
$1.4 \times 10^{8}$
41
357

$1.7 \times 10^{7}$
.14
9184

\footnotetext{
Conpyced for a thernite basalt analogue.

Bo (crit) 18 the critical Bond number (noralized to $r=1 \mathrm{~m}$ ) for sustained detonation; $v$ is the relative velocity between the melt and water produced by a propagating ghock through the aixture (for Chapnan-Jouguet conditions assuned to exist near $100 \mathrm{MPa}, U$ mat be approximately $60 \mathrm{~d} / \mathrm{s}$ to sustain a detonation); and $\mathrm{r}_{1}$ is the final particle size

formed by detonating waterfmelt interaction.
} 
There is good evidence from oxygen isotope analyses of erupted materials (Lipman and Friedman ${ }^{71}$ and Hildreth et al. ${ }^{72}$ ) that intermixing of meteoric water can occur at deep levels in the magma conduit system. The hypothesis that vaporization at the limit of superheating might develop stress waves of sufficient amplitude to trigger detonation is supported by the work of Shepherd and Sturtevant. 73 Their evaluation of the Landau instability that occurs during superheat vaporization is based on experimental and theoretical results. These results show that the maximurn far-field pressure developed by evaporative flux caused by the instability is given by

$$
\mathrm{P}_{\max }=\mathrm{dp} / \mathrm{dt}\left(\mathrm{t}_{\mathrm{o}}\right)
$$

where $\mathrm{dp} / \mathrm{dt}$ was measured at $1.4 \times 10^{2} \mathrm{MPa} / \mathrm{s}$, and measured $t_{0}$ was equal to $10^{2}$ $r_{0}$ ( $t_{0}$ in $\mu s$ and $r_{0}$, the preexpanded vapor film thickness, in millimeters). A C-J state pressure of $10^{2} \mathrm{Mpa}$ then requires a layer of water at the superheat 1imit of about $10 \mathrm{~m}$ thickness, which fits within 1imits Bennett ${ }^{74}$ considered possible for water/magma mixes during submarine hydrovolcanic explosions.

Furthermore, the harmonic tremor often recorded during volcanic eruptions can be explained by the fluid instabilities that develop during boiling heat transfer from the magma to groundwater. It is well understood that Landau and Taylor instabilities occur during initial stages of film boiling. The frequency and amplitude of these instablifties can be calculated for the planar Tayior type:

$$
n / n_{0}=\cosh (n t)
$$

and

$$
n=n_{0} \exp i(w t-m x)
$$

where $n / n_{0}$ is the ratio of instability thickness to intial vapor film thickness, $n$ is a function of the Taylor critical wavenumber and density contrasts between the liquid and vapor, $w$ is the frequency of the instability, and $m$ is the critical wave number. A further discussion of instabilities will not be given here; if film bolling proceeds at maximum heat flux, selsmic waves of sufficient amplitude may result to trigger strong melt/water intermixing at depth. 
VII. RECOMMNDATIONS

A. Mechanisms of Emplacement of Shallow Intrusions

Data are ambiguous concerning the significance of intrusion mechanisms of basalt magma. Based on abundant field data in the southern Great Basin, it appears unlikely that intruding magma would form major intrusion complexes in the Yucca Mountain environment. Moreover, it is unclear whether intrusions would increase the consequences of volcanic disruption of a repository. However, existing data, particularly the in situ stress measurements, suggest that sill-1ike intrusions could be formed during intrusion of basaltic magma beneath Yucca Mountain. In view of the low estimated probability of repository disruption by basaltic volcanism (Crowe et al. ${ }^{75}$ ), it does not appear necessary to undertake more extensive studies of intrusion mechanisms. We will continue to list this topic as an area of uncertainty in analyses of the radiological consequences of repository disruption by ascending magma.

B. Volcanic Patterns Through Time

Extensive data have been obtained on the volcanic patterns of the NTS region. There are no geologic or geochemical patterns to indicate that rates of volcanism in the NTS region are increasing, that they might increase in the future, or that the patterns could change toward a Type I field. Indeed, some data from both the NTS region and the southern Death Valley region indicate that these volcanic systems are in decline. The most active volcanic field in the DV-PR volcanic zone, the Lunar Crater volcanic fleld, shows distinct time-space and compositional patterns that are not shown by the basaltic volcanic record of the NTS region. Thus, it is reasonable to conclude that it is unlikely the volcanic field of the NTS region will become more active. Two cautions must accompany this interpretation. First, comparisons are made to only two volcanic fields in the volcanic zone--one is probably no longer active, the other is active. Do we have sufficient data to draw conclusions? The second and more serlous problem is the question of the past history and current state of tectonism in the NTS region. Because tectonic and volcanic processes are closely coupled, we must have more completely developed models of the time-space patterns of tectonism in the NTS region to complete volcanic studies. Tectonic investigations by the US Geological Survey are in progress. (Current concepts of the structural framework of Yucca Mountain are discussed by Carr. ${ }^{2}$ ) 


\section{Bimodal Volcanism}

Analyses of Drill Holes USW $\mathrm{VH}-1$ and VH-2 show that aeromagnetic anomalies of Crater Flat are not produced by buried rhyolite centers. This suggests that rhyolite volcanism has not been associated with the younger cycles of basaltic volcanism in Crater Flat. We can conclude from this data that the likelihood of future bimodal volcanism in the Crater Flat area is low. However, we are unable to explain the occurrence of silictc pumice dated at 6.3 Myr in the poorly indurated alluvium of southeast Crater Flat. Further work is proposed to drill both a positive magnetic anomaly in Crater Flat and a negative anomaly with a peripheral positive anomaly south of the town of Lathrop Wells. Results of the drilling may require modification of volcanic rate calculations and probability estimates and a reevaluation of the question of future bimodal volcanism.

D. Origin of Trace-Element-Enriched Basalt

Evidence presented in this report shows that the generation of traceelement-enriched basalt is not a unique young event. The trace-element and isotopic data suggest that the enrichment of the mantle source of these basalts must predate the basalts of the silicic episode. Thus, there is a low likelihood of a young (Quaternary age) trace-element-enrichment event. The exact cause of the trace-element enrichment of the mantle source for the basalts is controversial, and this question is currently a much-debated topic in igneous petrology.

\section{E. Hydrovolcanic Activity}

Three centers of hydrovolcanic activity are present in the NTS region; simflar centers are present throughout the southern Great Basin. The three centers exhibit hydrovolcanic activity in the early stages of eruptive activity; the successive activity was Strombolian. Tephra studies of deposits of Lathrop Wells confirm the hydrovolcanic origin of the center's early activity. These deposits contain a much greater abundance of country rock fragments than do the Strombolian deposits that were studied for consequence analyses. Selected calculations from the consequence studies may have to be repeated using bounds on the abundance of lithic fragments as determined in the hydrovolcanic deposits. Dimension data from hydrovolcanic craters indicate that exhumation of a repository by explosive cratering associated with 
water/magma interaction is unlikely--the depth of burlal of a repository at Yucca Mountain exceeds the crater depth of the largest known hydrovolcanic crater. Experimental data from FCIs and simulated hydrovolcanic explosions show that increased pressure does decrease the probability of magma/water explosions. These data are generally consistent with the spontaneous nucleation-pressure suppression model but less so with the thermal detonation model. The latter model is consistent with geologic evidence that magma/water explosions can occur at considerable depth under conditions where a triggering agent is provided (earthquake or stress wave propagation). Thus, we are faced with two important categories of evidence for the possibility of hydrovolcanic activity at Yucca Mountain: (1) theoretical models of magna/water interaction show that hydrovolcanic explosions are possible at the Yucca Mountain setting, and (2) geologic evidence shows that explosions that could lead to exhumation of a repository at Yucca Mountain are unlikely. Consequence studies of the radiological release rates associated with a basaltic eruption cycle at Yucca Mountain may have to be repeated using a modified eruption scenario. This scenario should consist of an early episode of hydrovolcanic activity followed by Strombolian activity for the duration of the eruption.

\section{F. Tectonic Framework of the NTS Region}

Field and laboratory studies of volcanic activity in the southern Great Basin are complete. Crowe et al. ${ }^{1}$ described a distinct volcanic zone (DV-PR zone) in which Quaternary volcanic activity is localized. The volcanic features of this zone are well known. However, the relationship of these features to the tectonic setting of the Yucca Mountain region cannot be adequately described until a more complete model of the tectonic framework of the region has been developed by the US Geological Survey. Summary discussions of the structural setting of Yucca Mountain and southwestern Nevada were presented by Carr. ${ }^{2}$ Data from ongoing geophysical investigations are required for further discussion of the relation between volcanic and tectonic features. 
1. B. M. Crowe, D. T. Vaniman, and W. J. Carr, "Status of Volcanic Hazard Studies for the Nevada Nuclear Waste Storage Investigations, "Los Alamos National Laboratory report LA-9325-MS (1983).

2. W. J. Carr, "Regional Structural Setting of Yucca Mountain, Southwestern Nevada, and Late Cenozolc Rates of Tectonic Activity in Part of the Southwestern Great Basin, Nevada and California," US Geological Survey open file report 84-854 (1984).

3. B. M. Crowe, S. Self, D. Vaniman, R. Amos, and F. Perry, "Aspects of Potential Magmatic Disruption of a High-Level Radioactive Waste Repository in Southern Nevada," J. Geol. 91, 259-276 (1983).

4. J. M. Stock, J. H. Healy, and S. H. Hickman, "Report on Televiewer $\log _{f}$ and Stress Measurements in Core Hole USW G-2, Nevada Test Site, October-November, 1982," US Geological Survey open file report 84-172 (1984).

5. D. T. Vaniman, B. M. Crowe, and E. S. Gladney, "Petrology and Geochemistry of Hawaite Lavas From Crater Flat, Nevada," Contrib. Mineral. Petrol. 80, 341-357 (1982).

6. A. Miyashiro, "Nature of Alkalic Volcanic Rock Series," Contrib. Mineral. Petrol. 66, 91-104 (1978).

7. M. G. Best and W. H. Brimhall, "Late Cenozoic Alkalic Basaltic Magmas in the Western Colorado Plateaus and the Basin and Range Transition Zone, U.S.A., and Their Bearing on Mantle Dynamlcs," Geol. Soc. Am. Bull. 85, 1677-1690 (1974).

8. A. Ewart, K. Baxter, and J. A. Ross, "The Petrology and Petrogenesis of the Tertiary Anorogenic Mafic Lavas of Southern and Central Queensland, Australia--Possible Implications for Crustal Thickening," Contrib. Mineral. Petro1. 75, 129-152 (1980).

9. M. G. Best and W. K. Hamblin, "Origin of the Northern Basin and Range Province: Implications from the Geology of its Eastern Boundary," Geol. Soc. Am. Mem. 152, 313-340 (1978).

10. D. Vaniman and B. M. Crowe, "Geology and Petrology of the Basalts of Crater Flat: Applications to Volcanic Risk Assessment for the Nevada Nuclear Waste Storage Investigations," Los Alamos National Laboratory report LA-8845-MS (1981).

11. J. A. Pearce, "Role of the Sub-Continental Lithosphere in Magma Genesis at Active Continental Margins," in C. J. Hawkesworth and M. J. Norry, Eds. ' Continental Basalts and Mantle Xenoliths (Shiva Publishing Limited, Cheshire, United Kingdom, 1983), pp. 230-249. 
12. S. C. Semken, "A Neodymium and Strontium Isotopic Study of Late Cenozoic Basalt Volcanism in the Southwestern Basin and Range Province," M.S. Thesis, University of California, Los Angeles (1984).

13. D. J. DePaolo and G. J. Wasserburg, "Inferences About Magma Sources and Mantle Structure from Variations of ${ }^{143} \mathrm{Nd} /{ }^{144} \mathrm{Nd}, "$ Geophys. Res. Lett. 3 , 743-746 (1976).

14. R. K. O'Nions, P. J. Hamilton, and N. M. Evensen, "Variations in $143 \mathrm{Nd} / 144 \mathrm{Nd}$ and $87 \mathrm{Sr} /{ }^{86} \mathrm{Sr}$ Ratios in Oceanic Basalts," Earth Planet. Sci. Lett. 34, 13-22 (1977).

15. C. E. Hedge and D. C. Nobel, "Upper Cenozoic Basalts with High Sr $87 / 86$ and $\mathrm{Sr} / \mathrm{Rb}$ Ratios, Southern Great Basin, Western United States," Geol. Soc. Am. Bu11. 82, 3503-3510 (1971).

16. D. H. Scott, "The Geology of the Southern Pancake Range and Lunar Crater Volcanic Field, Nye County, Nevada," Ph.D. Dissertation, University of California, Los Angeles (1969).

17. D. H. Scott and N. J. Trask, "Geology of the Lunar Crater Volcanic Field, Nye County, Nevada," US Geological Survey professional paper 599-I (1971).

18. C. J. Vitaliano and R. D. Harvey, "Alkali Basalt From Nye Canyon, Nevada," Am. Mineral. 50, 73-84 (1965).

19. N. J. Trask, "Ultramafic Xenoliths in Basalt, Nye County, Nevada," US Geological Survey professional paper 650-D pp. 43-48 (1969).

20. J. E. N. Pike, "Pressures and Temperatures Calculated for $\mathrm{Cr}-\mathrm{Rich}$ Pyroxene Composition of Megacrysts and Peridotite Xenoliths, Black Rock Summit, Nevada," Amer. Mineral. 61, 725-731 (1976).

21. S. C. Bergman, "Petrogenetic Aspects of the Alkali Basaltic Lavas and Included Megacrysts and Nodules from the Lunar Crater Volcanic Field, Nevada, USA," Ph.D. Dissertation, Princeton University (1982).

22. K. A. Foland, S. C. Bergman, A. W. Hofman, and I. Razcek, "Nd and Sr Isotopic Variations in Alkali Basalts and Megacrysts from the Lunar Crater Volcanic Field, Nevada," Trans. Am. Geophys. Union 64, 338 (1983).

23. B. D. Turrin and J. C. Dohrenwend, "K-Ar Ages of Basaltic Volcanism in the Lunar Crater Volcanic Field, Northern Nye County, Nevada: Implications for Quaternary Tectonism in the Central Great Basin," Abst. Geo1. Soc. Am. 16, p. 599 (1985).

24. R. L. Smith and R. G. Ludke, "Potentially Active Volcanic Lineaments and Loci in Western Conterminous United States," in Explosive Volcanism: Inception, Evolution and Hazards (National Academy Press, 1984) pp. 47-66. 
25. R. E. Anderson, "Structural Ties Between the Great Basin and Sonorar. Desert Sections of the Basin and Range Province," in K. A. Howard, M.D. Carr, and D. M. Miller, Eds., "Tectonic Framework of the Mojave and Sonoran Deserts, California and Arizona," US Geological Survey open file report 81-503 (1981) pp. 4-6.

26. R. J. Fleck, "Age and Tectonic Significance of Volcanic Rocks, Death Valley, California," Geol. Soc. Am. 19, 245-273 (1970).

27. H. Drewes, "Geology of the Funeral Peak Quadrangle, California, in the East Flank of Death Valley," US Geological Survey professional paper 413 (1963).

28. J. F. McAllister, "Geologic Map and Sections of the Furnace Creek Borate Area, Death Valley, Inyo County, California," Calif. Div. of Mines Geol. and Map Sheet MS-14 (1970).

29. J. F. McAllister, "Geological Map and Sections of the Amargosa Valley Borate Area-Southeast Continuation of the Furnace Creek Area-Inyo County, California," US Geological Survey Misc. Geol. Inv. Map I-782 (1973).

30. B. M. Crowe and W. J. Carr, "Preliminary Assessment of the Risk of Volcanism at a Proposed Nuclear Waste Repository in the Southern Great Basin," US Geological Survey open file report 80-375 (1980).

31. W. J. Carr, "Volcanic-Tectonic History of Crater Flat, Southwestern Nevada, as Suggested by New Evidence from Drill Hole USW-VH-l and Vicinity," US Geological Survey open file report 82-457 (1982).

32. M. F. Kane and R. E. Bracken, "Aeromagnetic Map of Yucca Mountain and Surrounding Regions, Southwest Nevada," US Geological Survey open file report 83-616 (1983).

33. C. J. Hawkesworth and M. J. Norry, Ed., Continental Basalts and Mantle Xenoliths (Shiva Publishing Limited, Cheshire, United Kingdom, 1983).

34. M. A. Menzies and V. R. Murthy, "Nd and Sr Isotopic Geochemistry of Hydrous Mantle Nodules and Their Host Alkali Basalt: Implications for Local Heterogeneties in Metasomatically Veined Mantle," Earth Planet. Sci. Lett. $46,323-334$ (1980).

35. M. Menzies, "Mantle Ultramafic Xenoliths in Alkaline Magmas: Evidence for Mantle Heterogeneity Modified by Magmatic Activity," in C. J. Hawkesworth and M. J. Norry, Eds., Continental Basalts and Mantle Xenoliths (Shiva Publishing Limited, Cheshire, United Kingdom, 1983) pp. 92-110.

36. R. V. Fisher and A. C. Waters, "Base-Surge Bed Forms In Maar Volcanoes," Am. J. Sci. 268, 157-180 (1970).

37. M. F. Sheridan and K. H. Wohletz, "Hydrovolcanism: Basic Considerations and Review," J. Volcanol. Geotherm. Res. 17, 1-29 (1983). 
38. G. R. Fowles, "Vapor Phase Explosions: Elementary Detonations?" Science 204, 168-169 (1979).

39. R. L. Rabie, G. R. Fowles, and W. Fickett, "The Polymorphic Detonation," Phys. Fluids 22, 422-435 (1979).

40. B. M. Crowe and R. V. Fisher, "Sedimentary Structures in Base-Surge Deposits with Special Reference to Cross Bedding, Ubehebe Craters, Death Valley, Callfornia," Geol. Soc. Am. Bull. 84, 663-682 (1973).

41. J. G. Moore and T. W. Sisson, "Deposits and Effents of the May 18 Pyroclastic Surge," US Geological Survey professional paper 1250 (1981), pp. 421-438.

42. M. F. Sheridan and K. H. Wohletz, "Hydrovolcanic Explosions: The Systematics of Water-Pyroclast Equilibration," Science 212, 1387-1389 (1981).

43. K. H. Wohletz and R. G. McQueen, "Experimental Studies of Hydromagmatic Volcanism," in Explosive Volcanism: Inception, Evolution, and Hazards, studies in Geophysics (National Academy Press, 1984), pp. 158-169.

44. M. F. Sheridan, F. Barberi, M. Rosi, and R. Santacroce, "A Model for Plinian Eruptions of Vesuvius," Nature 22, 292-285 (1981).

45. G. P. L. Walker and R. Croasdale, "Characteristics of Some Basaltic Pyroclastics," Bull. Volcanol. 35, 305-317 (1971).

46. G. H. Heiken, "Morphology and Petrography of Volcanic Ashes," Geol. Soc. Am. Bul1. 83, 1961-1988 (1972).

47. G. H. Heiken, "An Atlas of Volcanic Ash," Smithsonian Contrib. Earth Sci. $12(1974)$.

48. K. H. Wohletz, "Chemical and Textural Surface Features of Pyroclasts from Hydromagmatic Eruption Sequences," in J. R. Marshall, Ed., "Characterization and Quantification of Surface Features on Clastic and Pyroclastic Particles," Los Alamos National Laboratory document LA-UR83-250 (1983).

49. K. H. Wohletz, "Mechanisms of Hydrovolcanic Pyroclast Formation: Grain-Size, Scanning Electron Microscopy, and Experimental Results," J. Volcanol. Geotherm. Res. 17, 31-63 (1983).

50. D. L. Inman, "Measures for Describing the Size Distribution of Sediments," J. Sed. Pet. 22, 125-145 (1952).

51. M. F. Sheridan and J. R. Marshall, "SEM Examination of Pyroclastic Materials: Basic Considerations" (SEM Inc., AMF O'Hare, Illinois, 1982).

52. K. H. Wohletz and D. H. Krinsley, "Scanning Electron Microscopic Analysis of Basaltic Hydromagmatic Ash," in B. Whalley and D. Krinsley, Eds., "Scanning Electron Microscopy in Geology," Los Alamos National Laboratory document LA-UR-82-1433 (1982). 
53. P. Rez and J. Konopka, "Limitations in the Use of the Peak-to-Background Method for Quatitative Analysis," X-Ray Spect. 13, 33-37 (1984).

54. R. J. Pike and G. D. Clow, "Revised Classification of Terrestrial Volcanoes and Catalog of Topographic Dimensions, With New Results on Edifice Volume," US Geological Survey open file report 81-1038 (1981).

55. "Core-Meltdown Experimental Review," Sandia National Laboratories report SAND74-0382 (1975).

56. L. D. Buxton and W. B. Benedict, "Steam Explosion Efficiency Studies," Sandia National Laboratories report SAND79-1399, NUREG/CR-0947 (1979).

57. M. L. Corradini, "Phenonenological Modelling of the Triggering Phase of Smal1-Scale Steam Explosion Experiments," Nucl. Sci. Eng. 78, 154-170 (1981).

58. G. Fröhlich, G. Müller, and G. Unger, "Experiments With Water and Hot Melts of Lead," J. Non-Equil. Thermodyn. 1, 91-103 (1976).

59. T. A. Dullforce, D. J. Buchanan, and R. S. Peckover, "Self Triggering of Small-Scale Fuel-Coolant Interactions: I. Experiments," J. Phys. D: Appl. Phys. 9, 1295-1303 (1976).

60. L. S. Nelson and L. D. Buxton, "Steam Explosion Triggering Experiments with Oxidized Corium-E Simulants," Trans. Am. Nucl. Soc. 28, 448 (1978).

61. B. Sturtevant and D. Frost, "Effects of Ambient Pressure on the Instability of a Liquid Bolling Explosively at the Superheat Limit," Proc. Fundamentals of Phase Change: Bolling and Condensation, Am. Soc. Mech. Eng. Ann. Meet. (1984).

62. R. C. Reid, "Superheated Liquids," Am. Sc1. 64, 146-156 (1976).

63. R. E. Henry and C. M. Miyazaki, "Effects of System Pressure on the Bubble Growth From Highly Superheated Water Droplets," In S. G. Bankoff, Ed., Topics in Two-Phase Heat Transfer and Flow (Am. Soc. Mech. Eng., New York, 1978), pp. 1-10.

64. S. J. Board, R. W. Hal1, and R. S. Hall, "Detonation of Fuel Coolant Explosions," Nature 254, 319-321 (1975).

65. P. D. Patel and T. G. Theofanous, "Fragmentation Requirements for Detonating Thermal Explosions," Nature 274, 142-144 (1978).

66. D. W. Condiff, "Contributions Concerning Quasi-Steady Propagation of Thermal Detonations Through Dispersions of Hot Liquid Fuel in Cooler Volatile Liquid Coolants," Int. J. Heat Mass Trans. 25, 87-98 (1982).

67. A. Sharon and S. G. Bankoff, "On the Existence of Steady Supercritical Plane Thermal Detonations," Int. J. Mass Heat. Trans. 24, 1561-1572 (1981). 
68. H. K. Fauske, "Some Comments on Shock-Induced Fragmentation and Detonating Thermal Explosions," Trans. Am. Nucl. Soc. 27, 666-667 (1977).

69. S. G. Bankoff and J. H. Jo, "Existence of Steady-State Fuel-Coolant Themal Detonation Waves," ERDA Report NU-2512-6, CONF-760328-8 (1976).

70. D. S. Drumheller, "The Initiation of Melt Fragmentation in Fue1-Coolant Interactions," Nucl. Scl. Eng. 72, 347-356 (1979).

71. P. W. Lipman and I. Friedman, "Interaction of Meteoric Water with Magma: An Oxygen Isotope Study of Ash-Flow Sheets from Southern Nevada," Geol. Soc. Am. Bul1. 86, 695-702 (1975).

72. W. Hildreth, R. L. Christlansen, and J. R. O'Ne1l, "Catastrophic Isotopic Modification of Rhyolitic Magma at Times of Caldera Subsidence, Yellowstone Plateau Volcanic Field," J. Geophys. Res. 89, 8339-8370 (1984).

73. J. E. Sheppherd and B. Sturtevant, "Rapid Evaporation at the Superheat Limit," J. F1uid Mech. 121, 379-402 (1982).

74. F. D. Bennett, "On Volcanic Ash Formation," Am. J. Sci. 274, 648-661 (1974).

75. B. M. Crowe, M. E. Johnson, and R. J. Beckman, "Calculation of the Probability of Volcanic Disruption of a High-Level Radioactive Waste Repository Within Southern Nevada, USA," Radioactive Waste Management 3 , 167-190 (1982).

76. N. W. Bower, "Optimization of Precision and Accuracy in X-Ray Fluorescence Analysis of Silicate Rocks," Appl. Spectrosc. (in press).

77. E. S. Gladney, D. B. Curtis, D. R. Perrin, J. W. Owens, and W. E. Goode, "Nuclear Techniques for the Chemical Analysis of Environmental Materials," Los Alamos National Laboratory report LA-8192-MS (1980).

78. E. S. Gladney, D. R. Perrin, J. P. Balagna, and C. L. Warner, "Evaluation of a Boron-Filtered Epithermal Neutron Actlvation Facility," Anal. Chem. 52, 2128-2132 (1980).

79. E. S. Gladney, D. R. Perrin, W. K. Hensley, and M. E. Bunker, "Urantum Content of Twenty-Five Silicate Reference Materials," Geostand. News1. 4. 243-246 (1980).

80. E. S. Gladney, J. W. Owens, T. C. Gunderson, and W. E. Goode, "Qual1ty Assurance for Environment Analytical Chemistry 1976-1979," Los Alamos National Laboratory report LA-8730-MS (1981). 
계

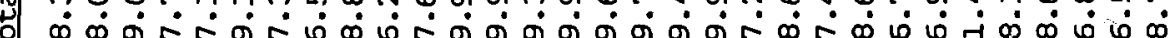

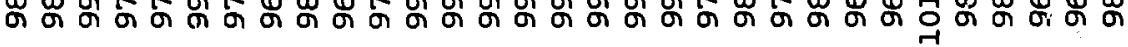

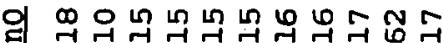
ச்

Q

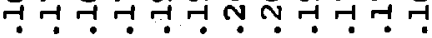
ல் $\dot{0} \dot{0} 0 \dot{0} \dot{0} \dot{0} \dot{0}$

40

$\times$

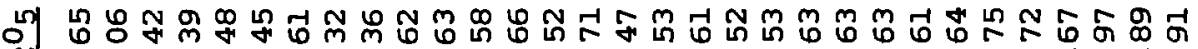

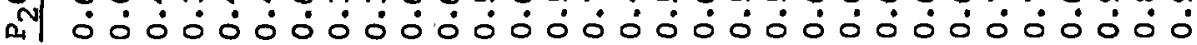

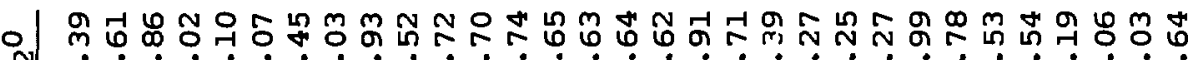
ڤ્વ

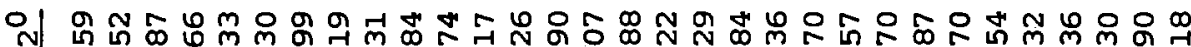

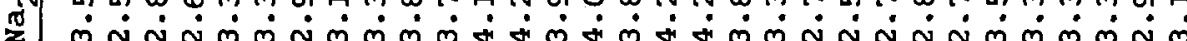

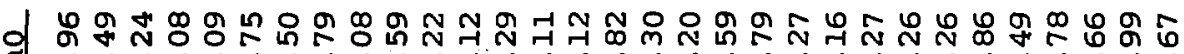

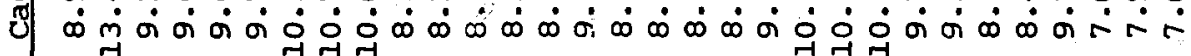

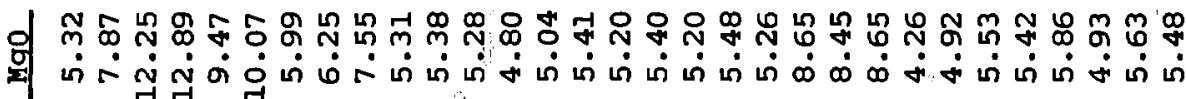

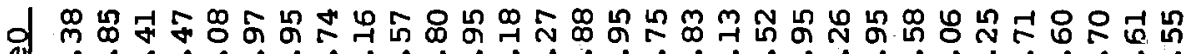

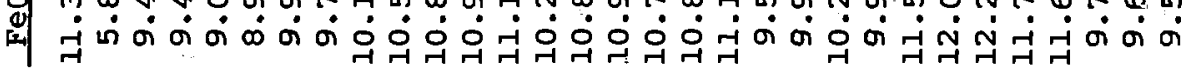

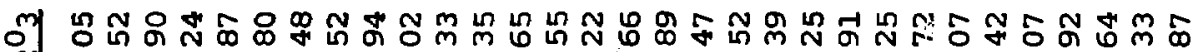

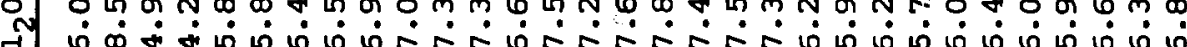

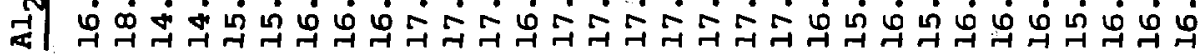

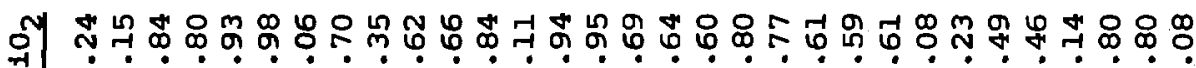
सी

क्षे

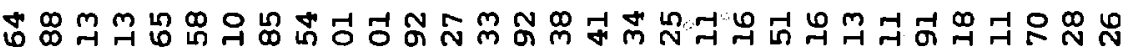

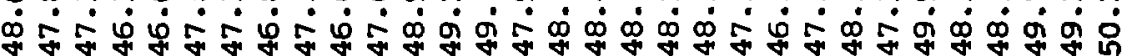

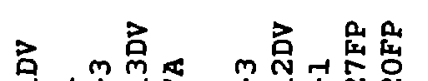

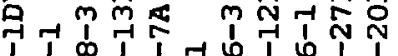

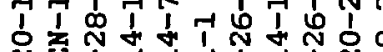

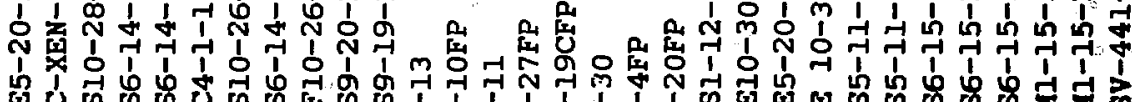

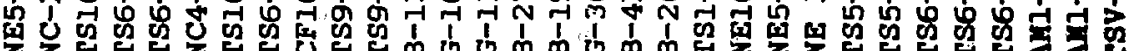




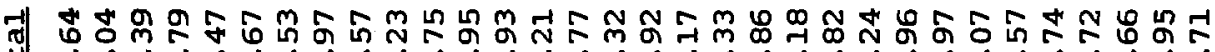

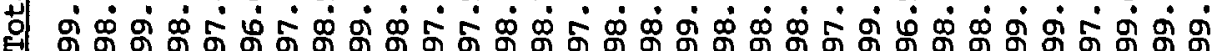

워두 궐

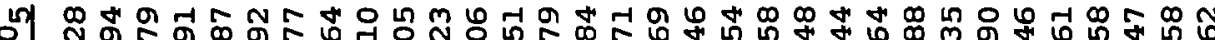

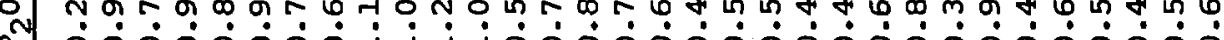

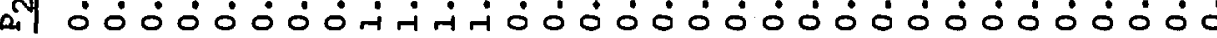

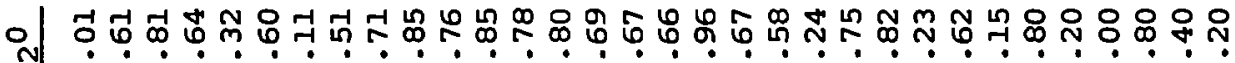

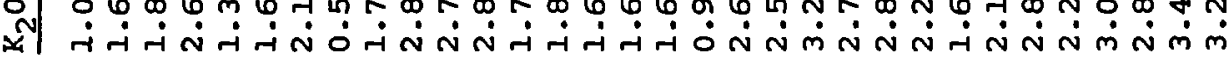

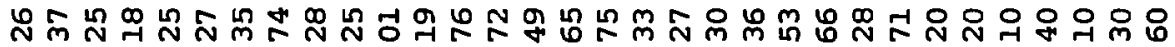

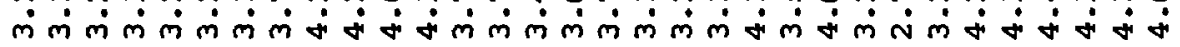

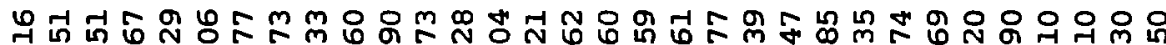

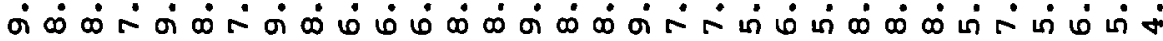

읙해

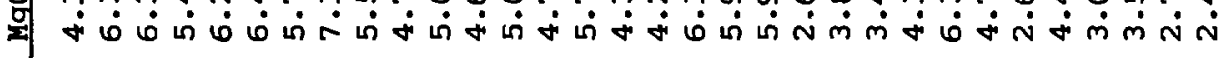

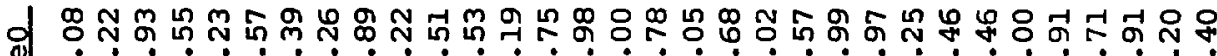

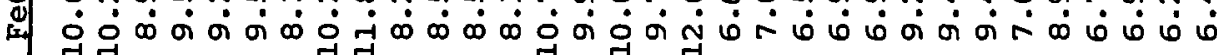

애

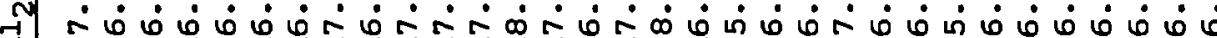

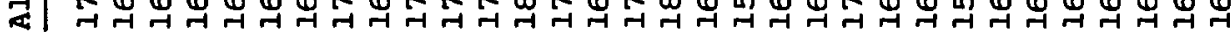

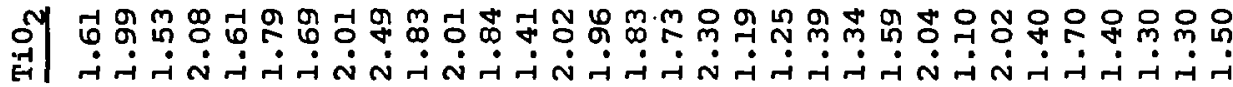

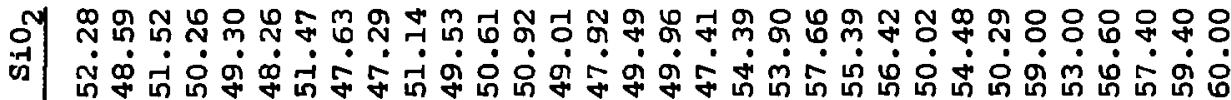

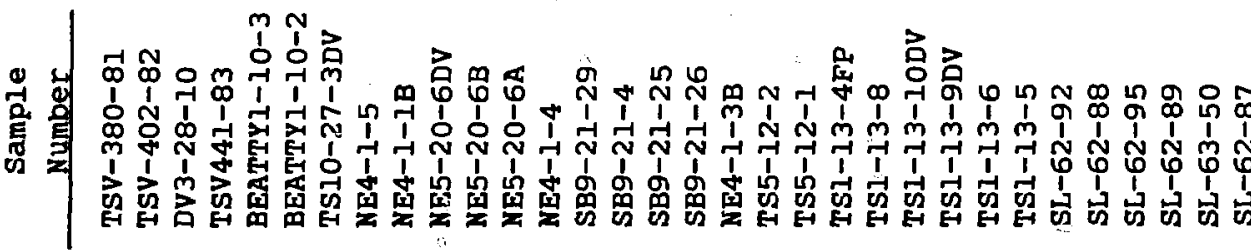


島

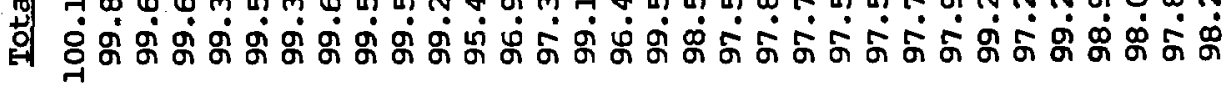

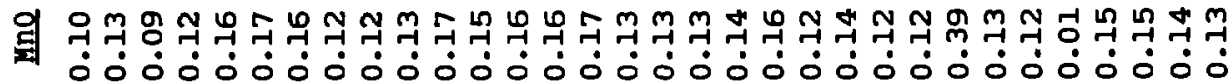

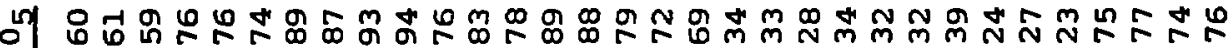

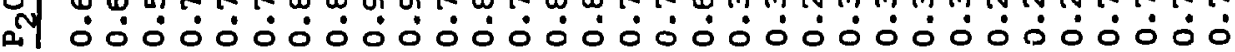

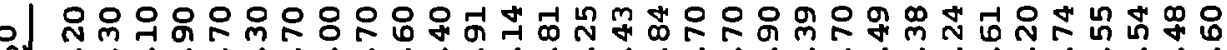

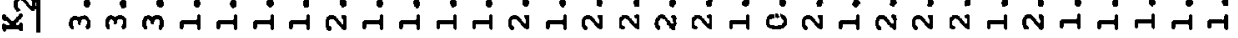

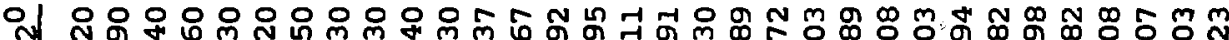
गै जै 2) $+* m m m m m m m N m N m m m m N N m N m m N N N N m m m$

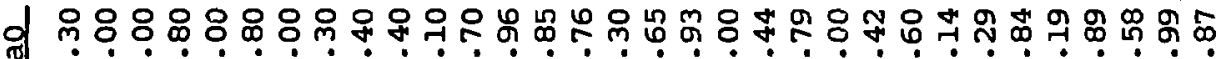

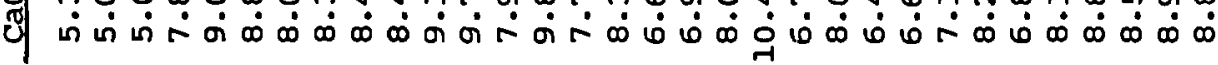

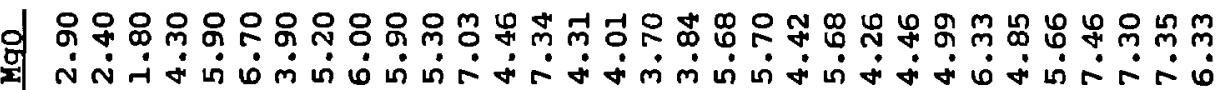

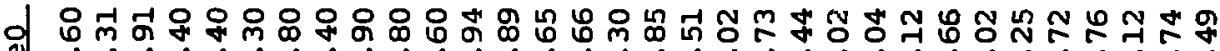

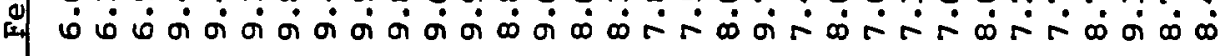

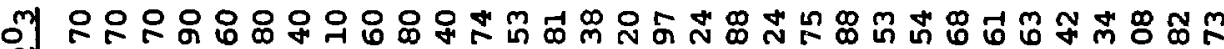
年

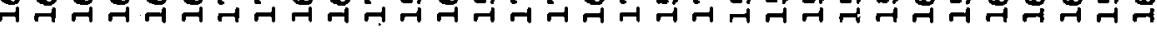

E.

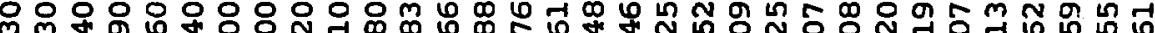

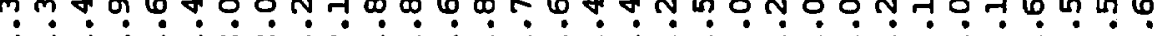

옥웁요

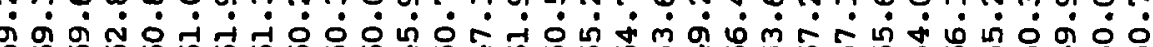
ํํำ 


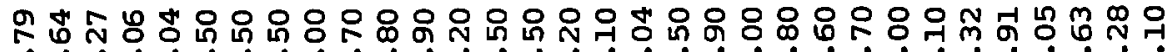

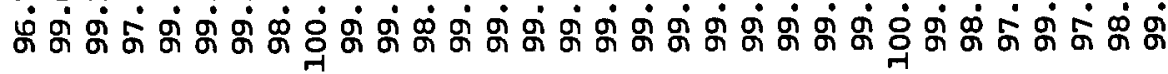

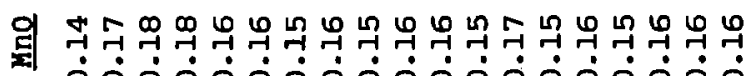

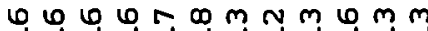
0 $\dot{0} \dot{0} \dot{0} \dot{0} \dot{0} \dot{0} \dot{0} \dot{0} \dot{0} \dot{0} \dot{0} \dot{0} \dot{0} \dot{0} \dot{0} \dot{0} \dot{0} \dot{0} \dot{0} \dot{0} \dot{0} \dot{0}$

메 붕 m

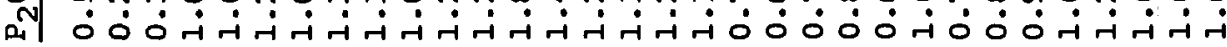

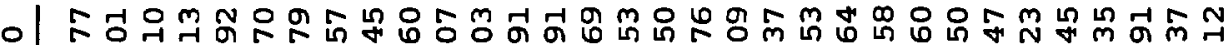

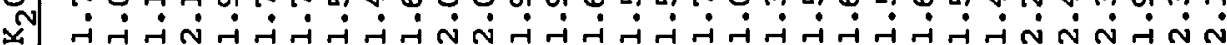

의 \& $\dot{\sim} \dot{m} \dot{m} \dot{m} \dot{m} \dot{m} \dot{m} \dot{m} \dot{m} \dot{m} \dot{m} \dot{m} \dot{m} \dot{m} \dot{m} \dot{m} \dot{N} \dot{m} \dot{N} \dot{N} \dot{m} \dot{m} \dot{m} \dot{m}$

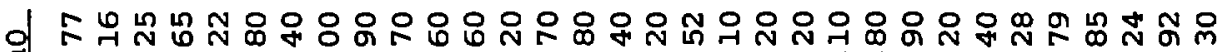
U

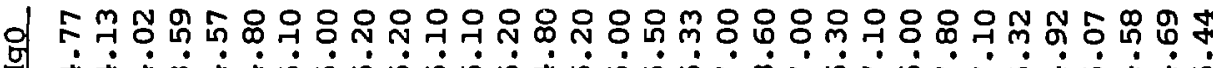

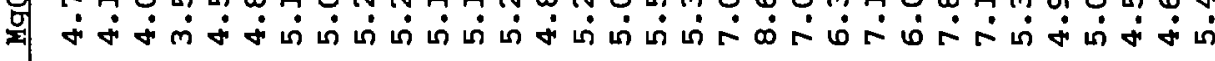

어

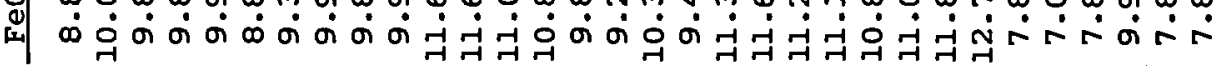

m i 岸

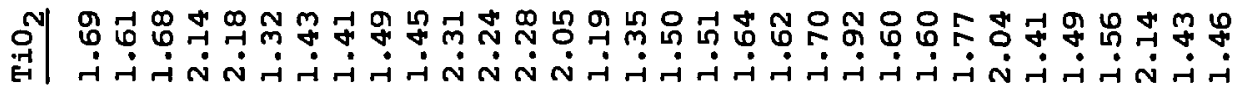

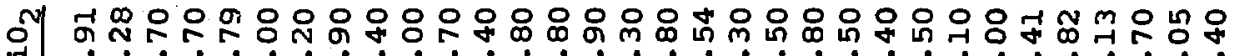

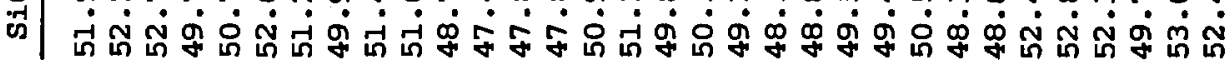

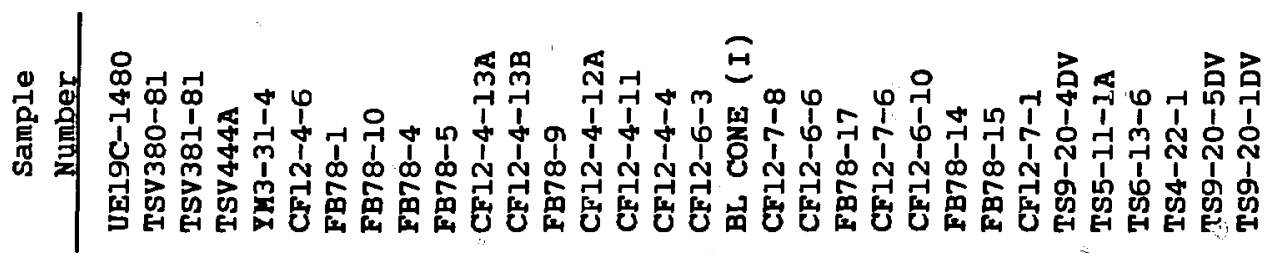




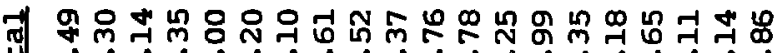

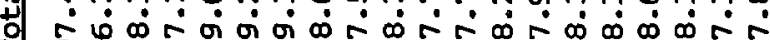

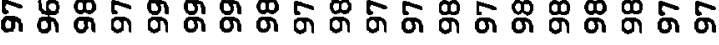

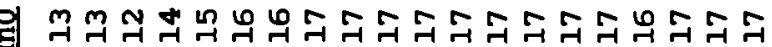
○் ல்

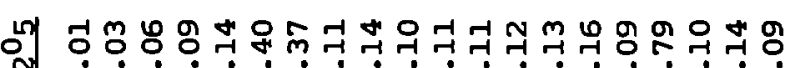

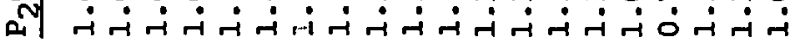

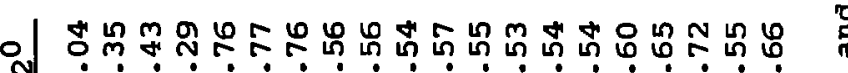

ฟ

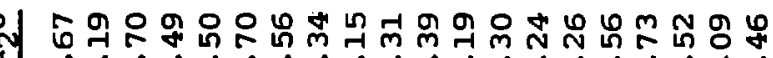
要 $\dot{m} \dot{m} \dot{m} \dot{m} \dot{m} \dot{m} \dot{m} \dot{m} \dot{m} \dot{m} \dot{m} \dot{m} \dot{m} \dot{m} \dot{m}$

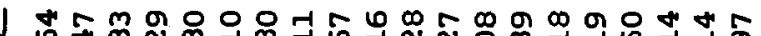
(ी)

舟

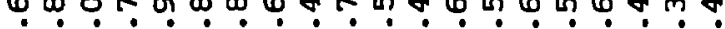
ก

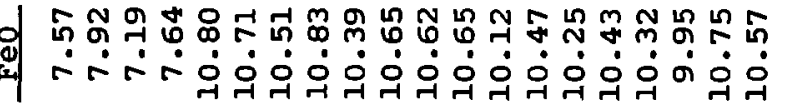

㖞

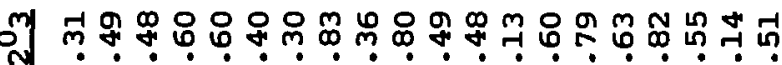

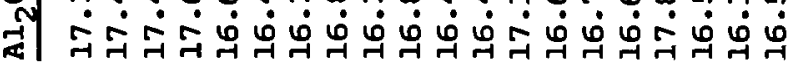

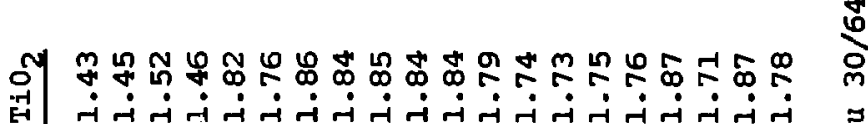

니 T.

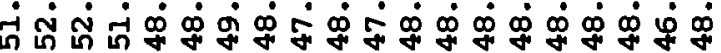

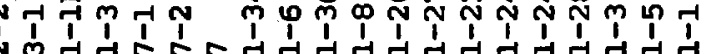

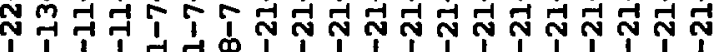

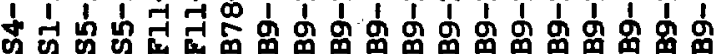

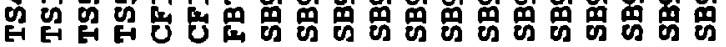

㟧

范

ấ.

我蓄

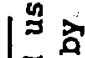

冚 


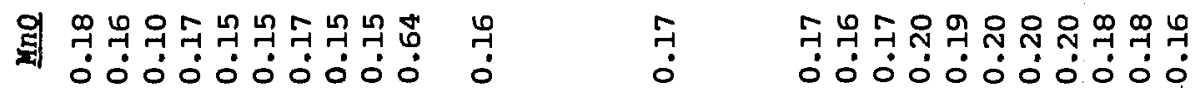

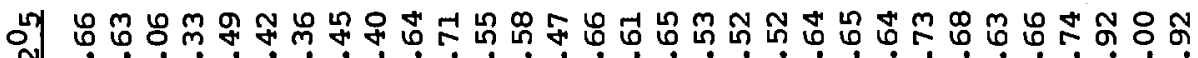

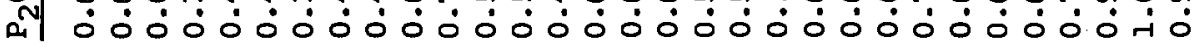

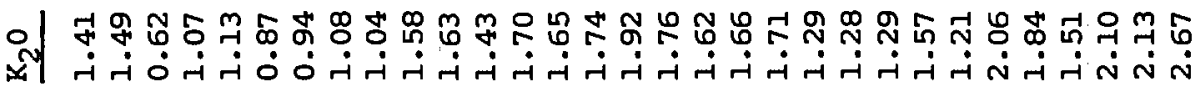

엥 농ㄷำ

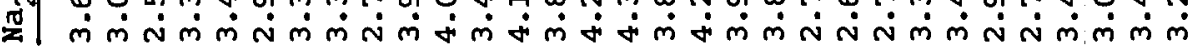

의국ํํำ

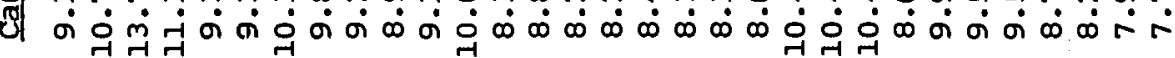

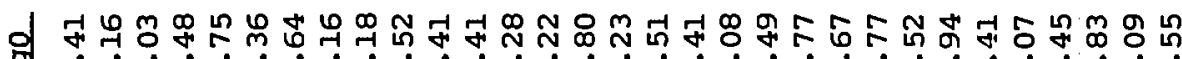

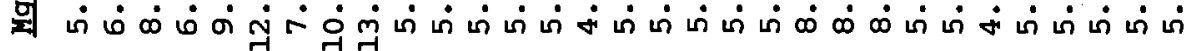

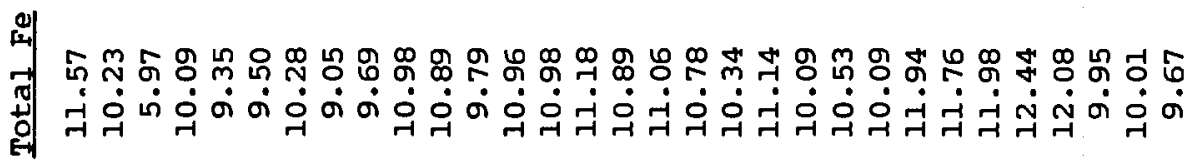

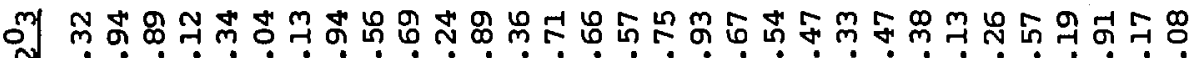

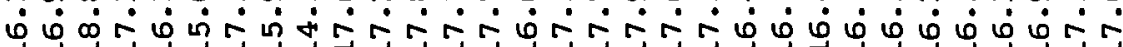

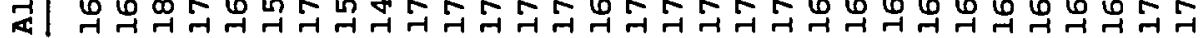

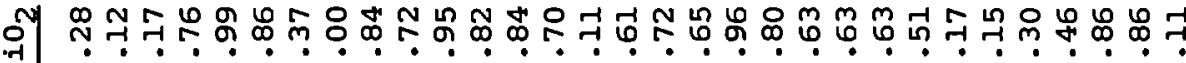

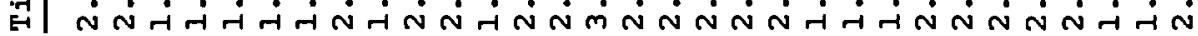

ơ

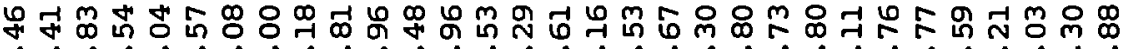

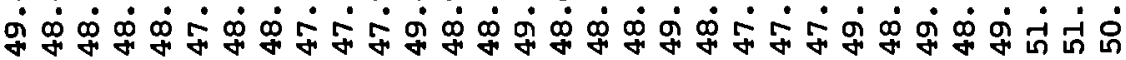

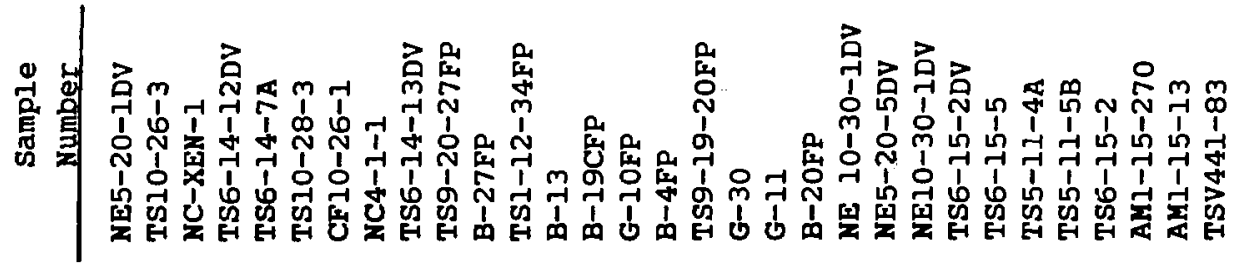




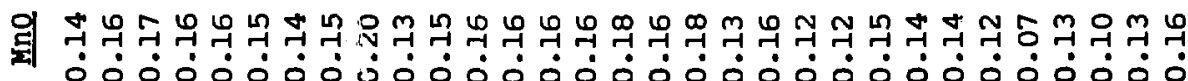

에 윤

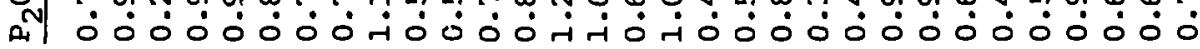

O

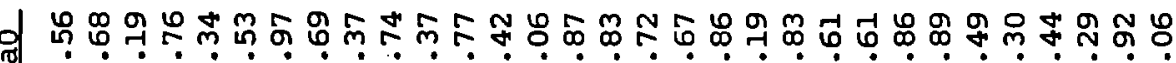
ठ

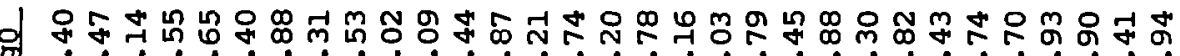

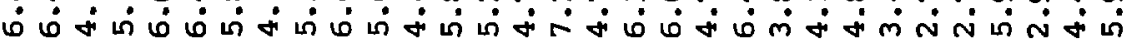

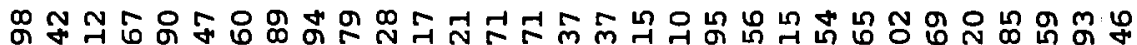

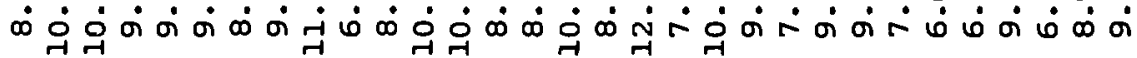

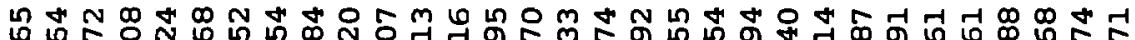

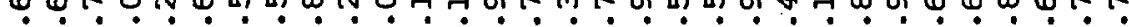

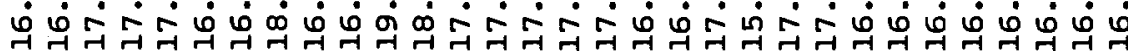

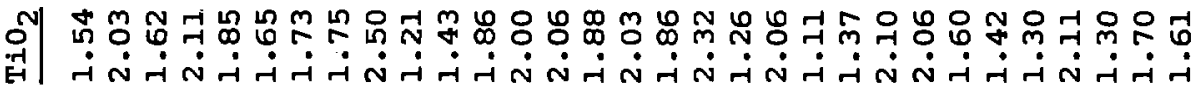

廿 ๒

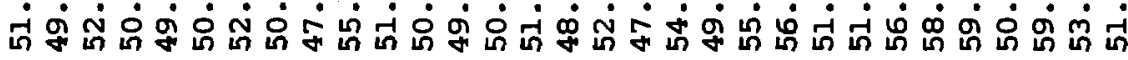

N

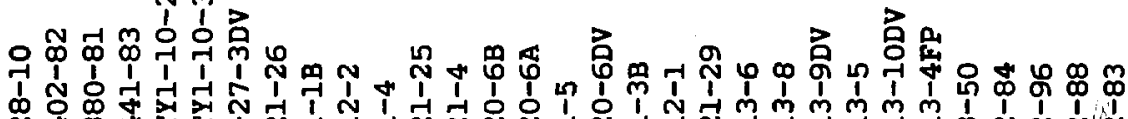

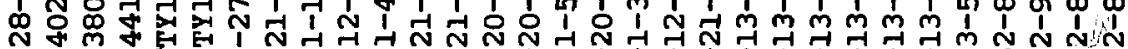
1 1 T

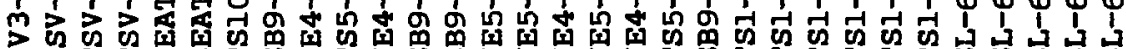




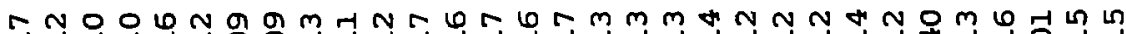

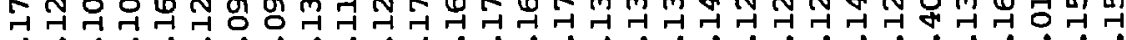

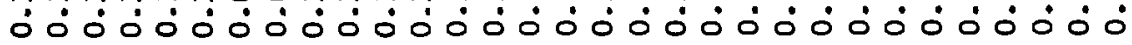

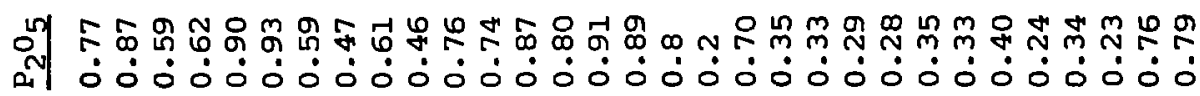

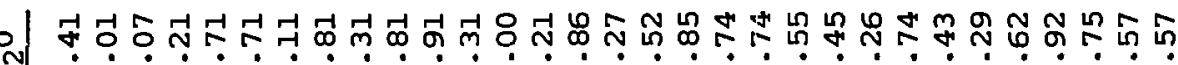

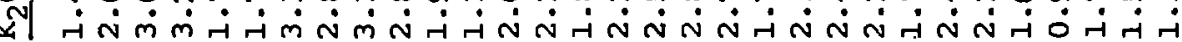

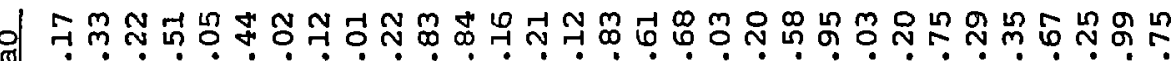

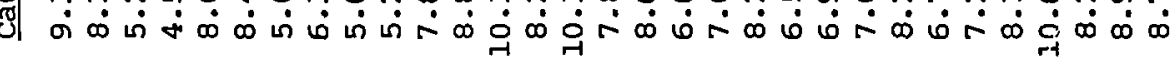

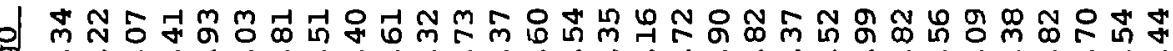

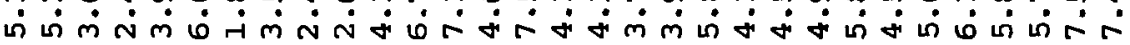

ம

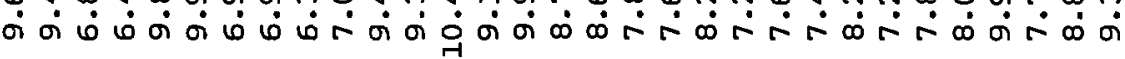

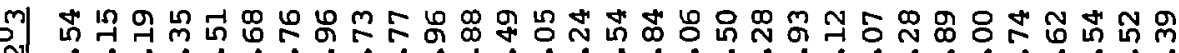

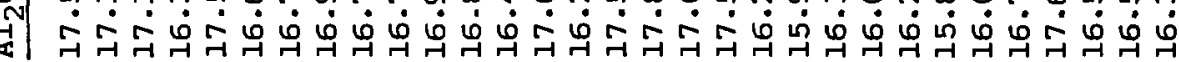

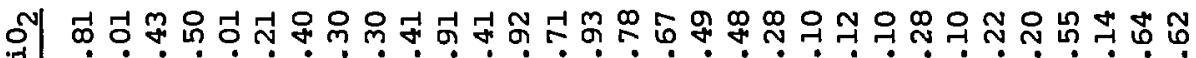

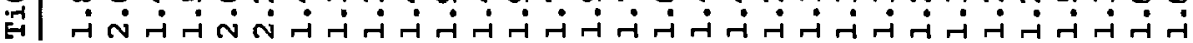

ind

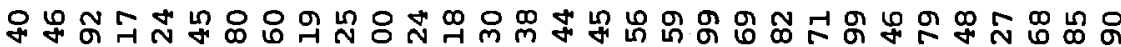

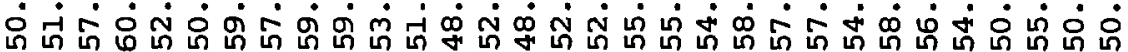

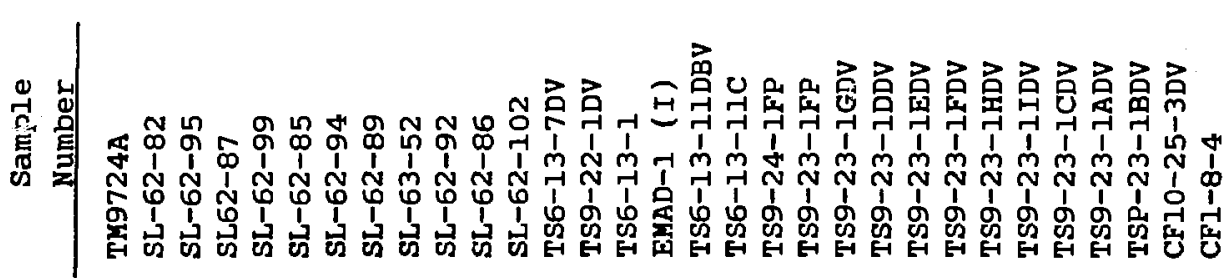


웣

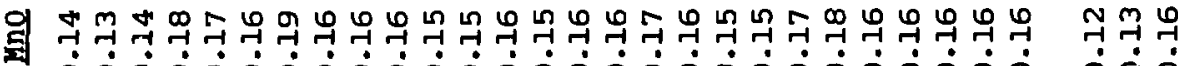

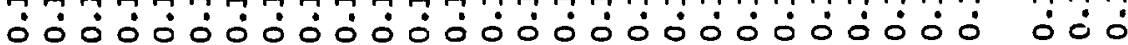

เు

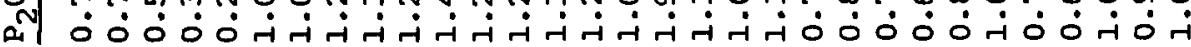

에ำ

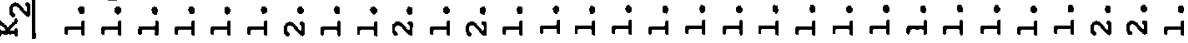

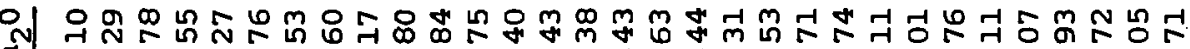
¿ $\dot{m} \dot{m} \dot{N} \dot{m} \dot{m} \dot{m} \dot{m} \dot{m} \dot{m} \dot{m} \dot{m} \dot{m} \dot{m} \dot{m} \dot{m} \dot{m} \dot{N} \dot{N} \dot{m} \dot{N} \dot{m} \dot{m} \dot{m} \dot{m} \dot{m}$

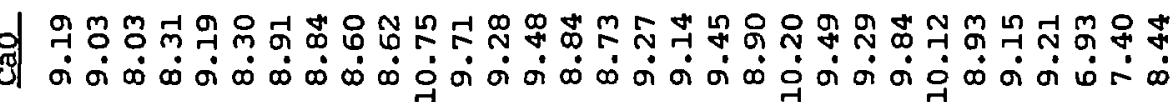

변

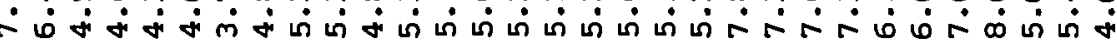

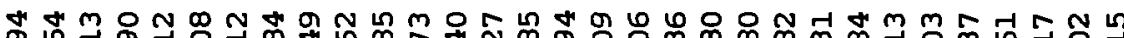
! ? ? ? ? ? ? ? ? ? ? ? ? ?

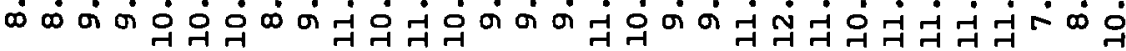

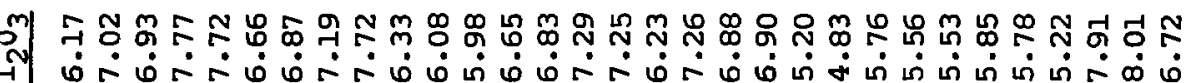
芹

위

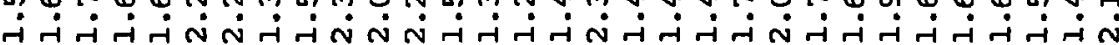

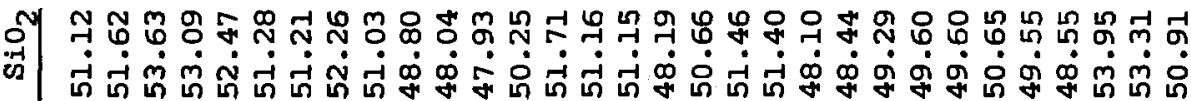

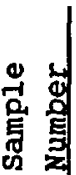

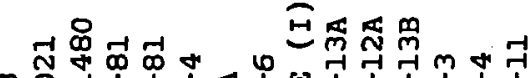

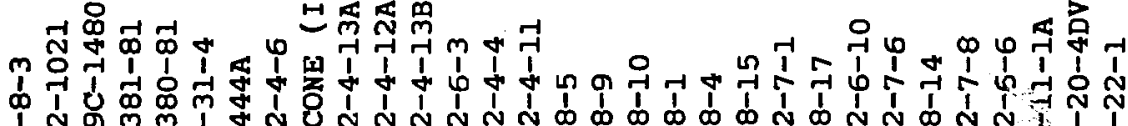

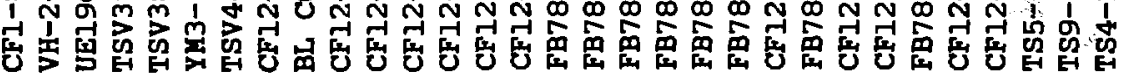


역

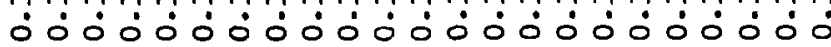

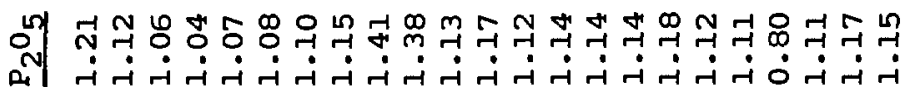

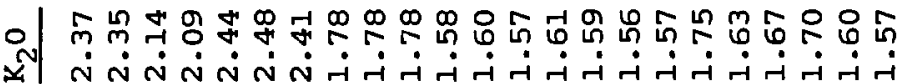

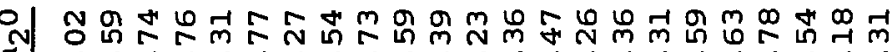
更 $\dot{m} \dot{m} \dot{m} \dot{m} \dot{m} \dot{m} \dot{m} \dot{m} \dot{m} \dot{m} \dot{m} \dot{m} \dot{m} \dot{m} \dot{m} \dot{m} \dot{m} \dot{m}$

d U

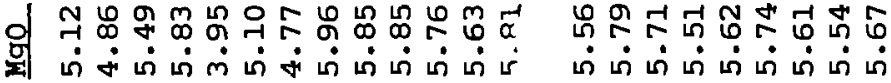
年

m $\dot{0} \dot{0} \dot{0} \dot{0} \ddot{0} \dot{0} \dot{0} \dot{0} \dot{0} \dot{0} \dot{0} \dot{0} \dot{0} \dot{0} \dot{0} \dot{0} \dot{0} \dot{0}$ ભ

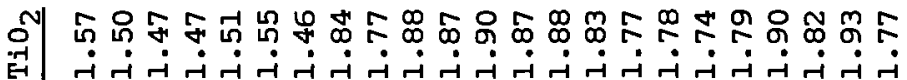

싱

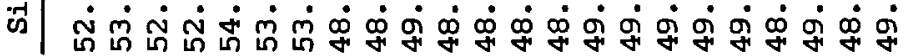

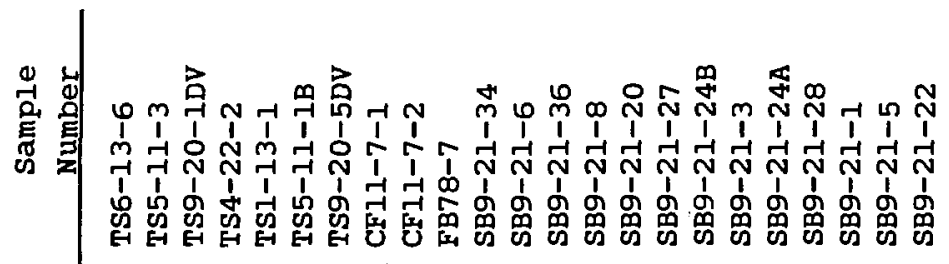


嵌 䟢

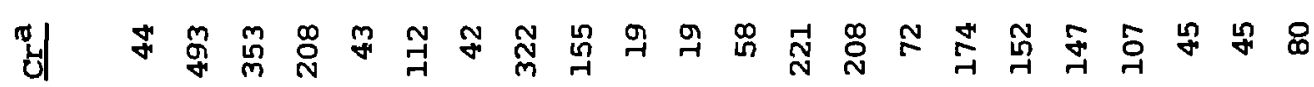

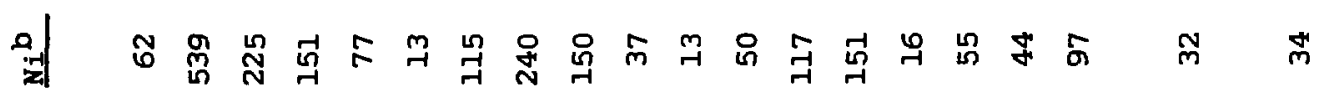

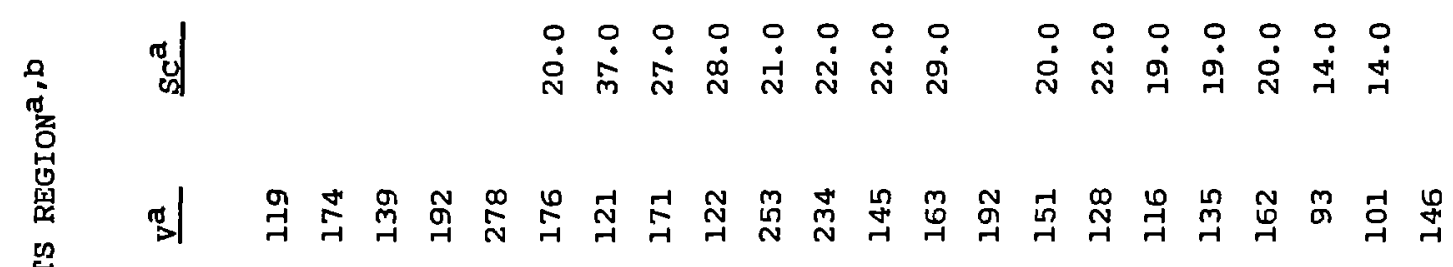

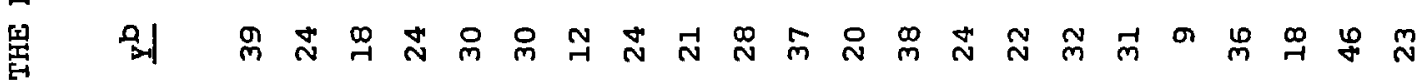
區

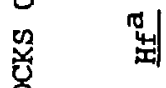

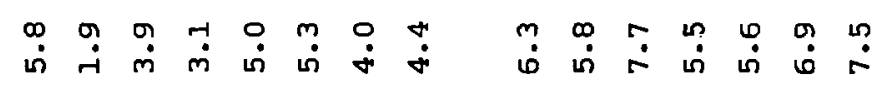

ن

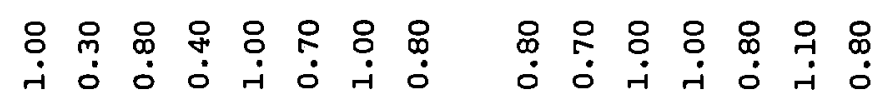

象

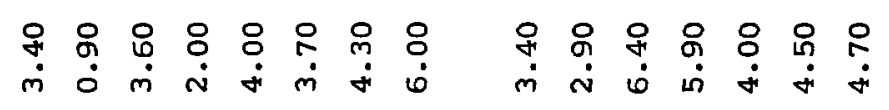

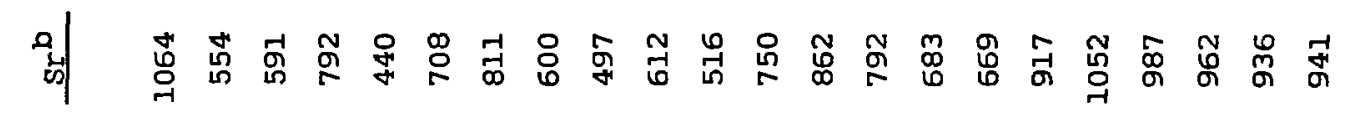

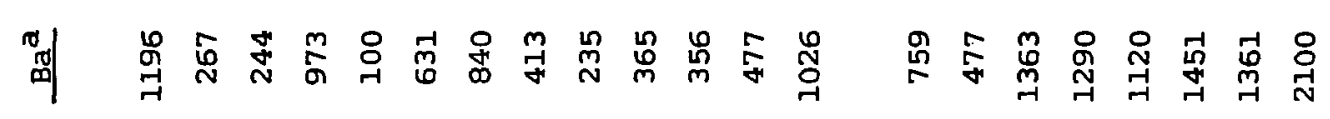

串

맹

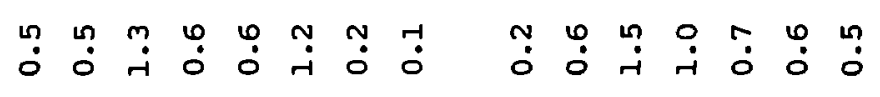

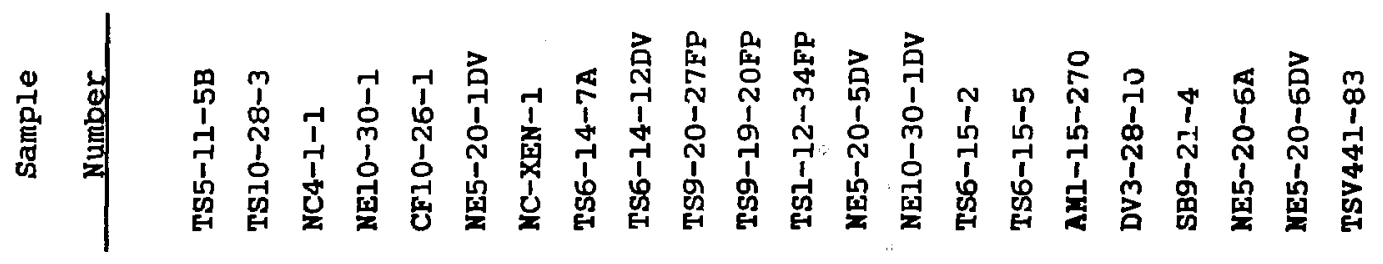




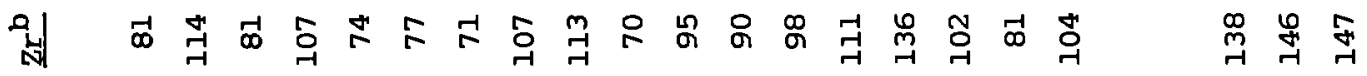

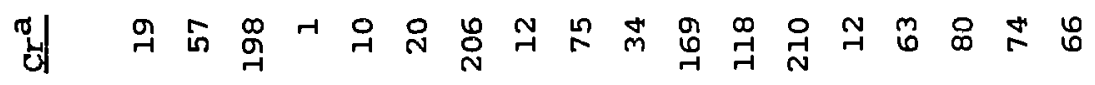

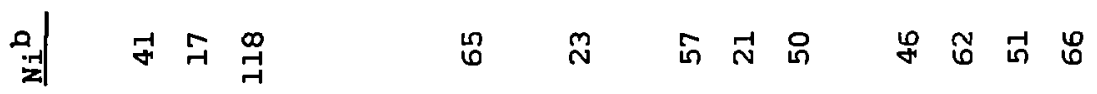

䓂

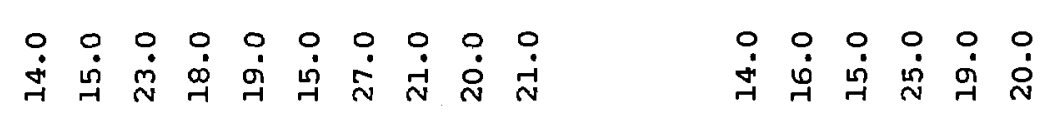

尊

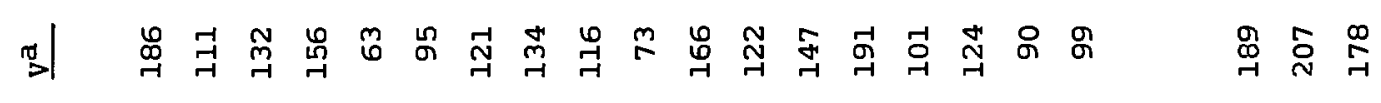

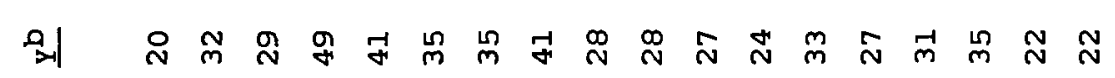

羅

崖影

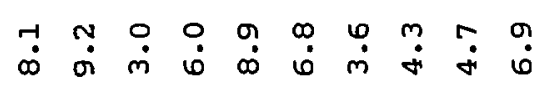

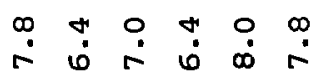

幽

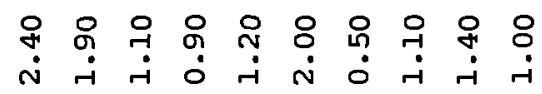

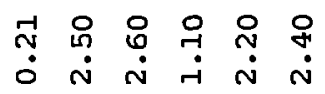

䠞

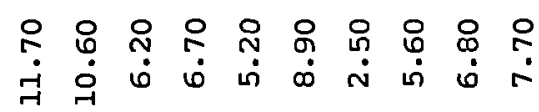

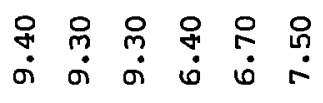

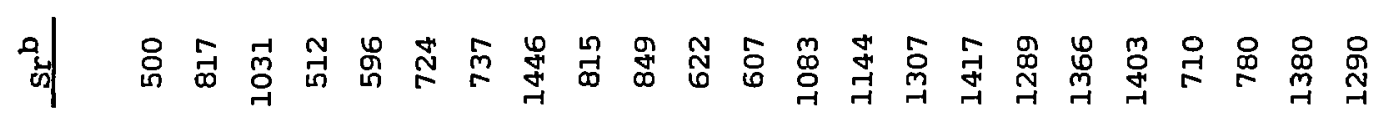

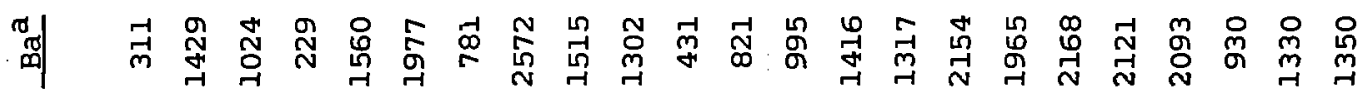

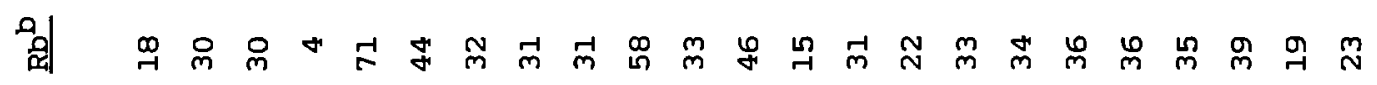

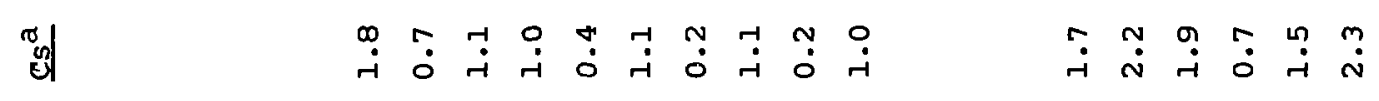

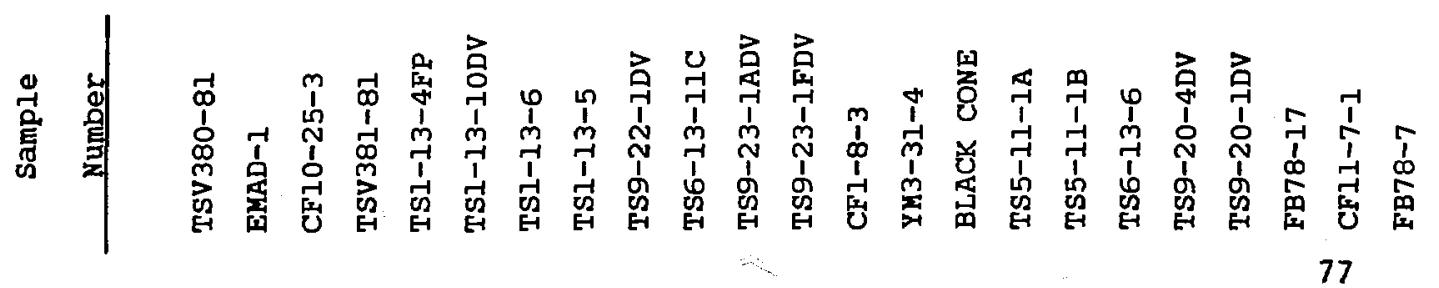




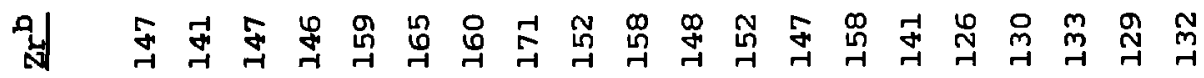

암

$-10$

a)

俈

号

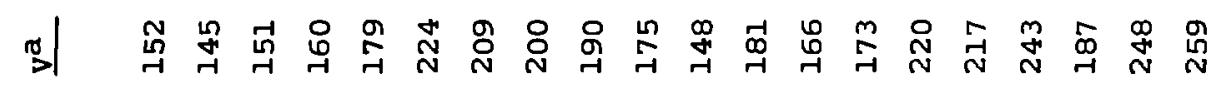

舆 क्ञा

窟

究

萄

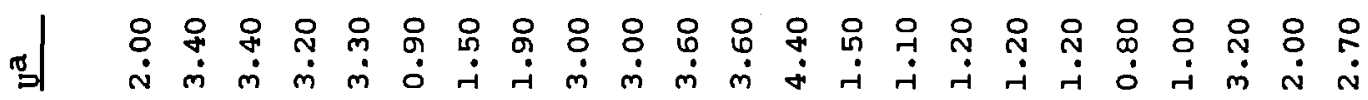

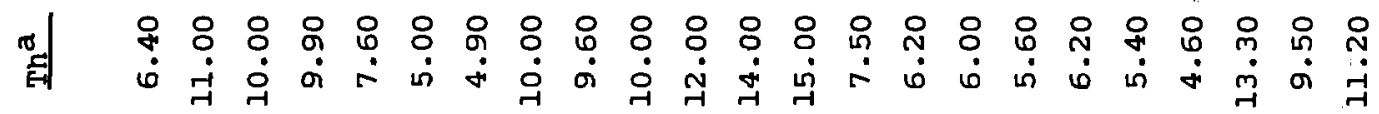

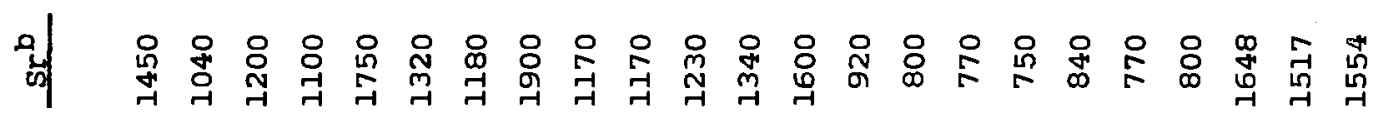

呂

暂

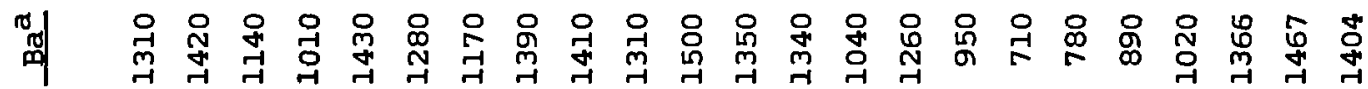

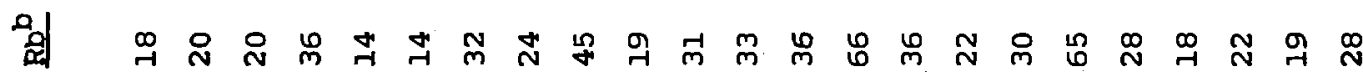

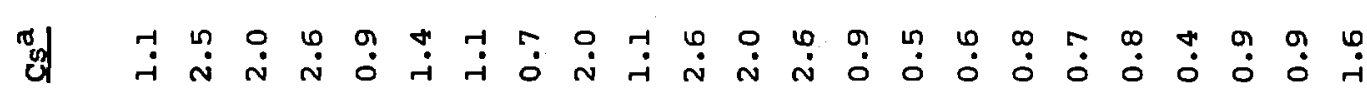

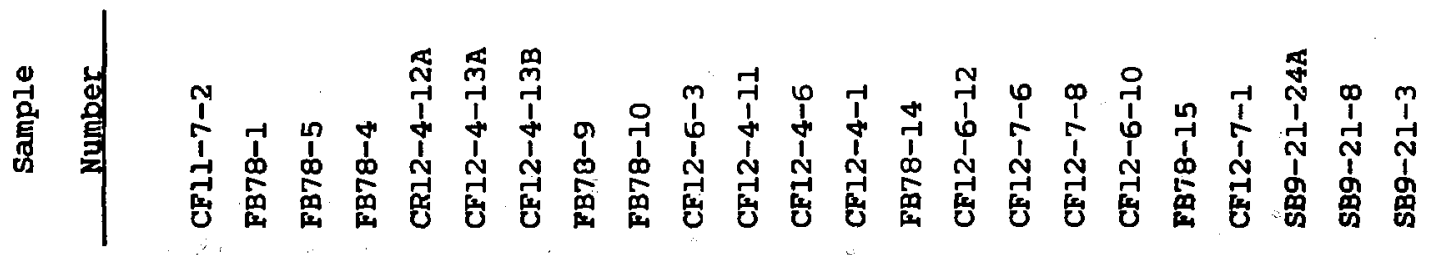




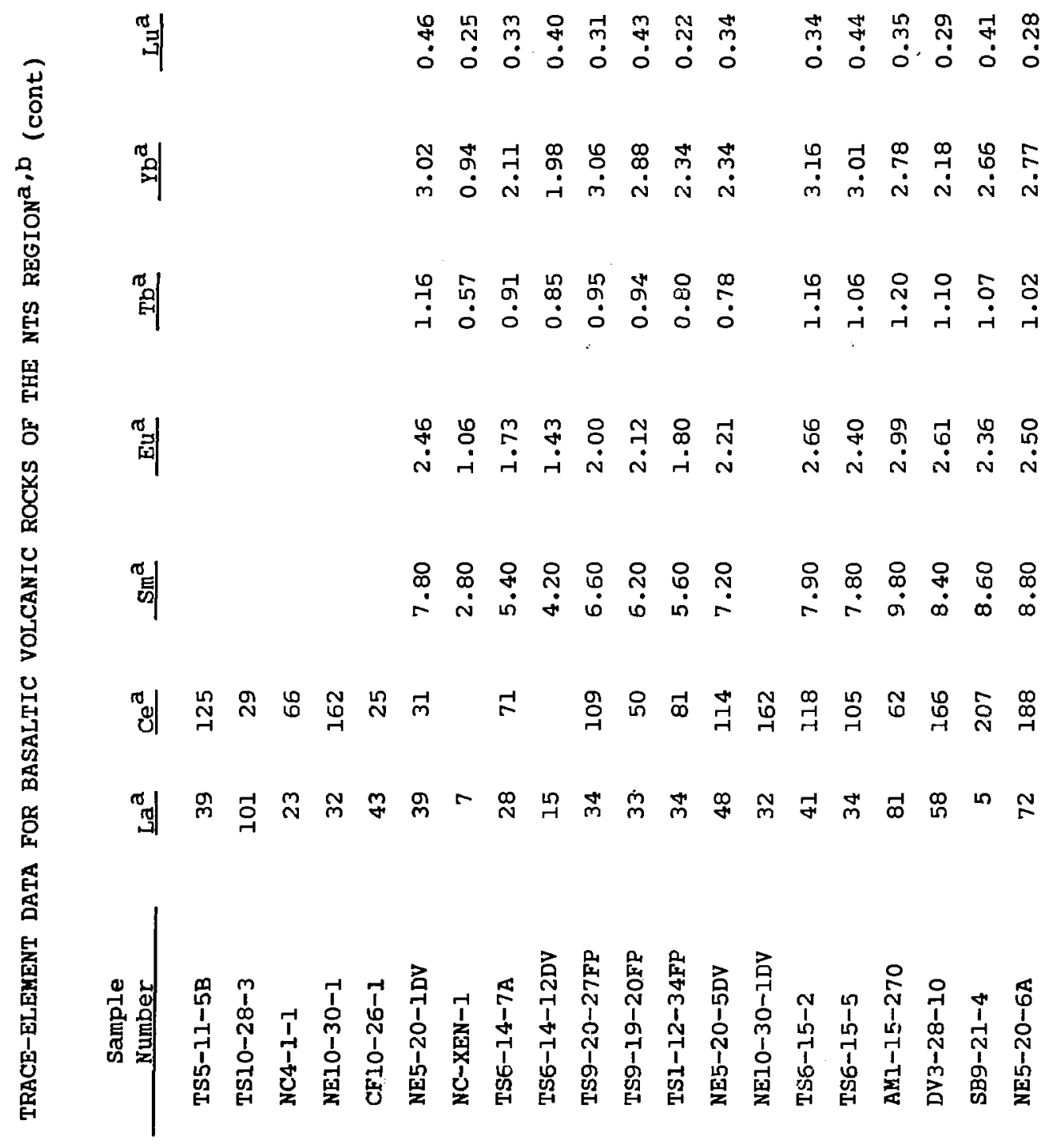




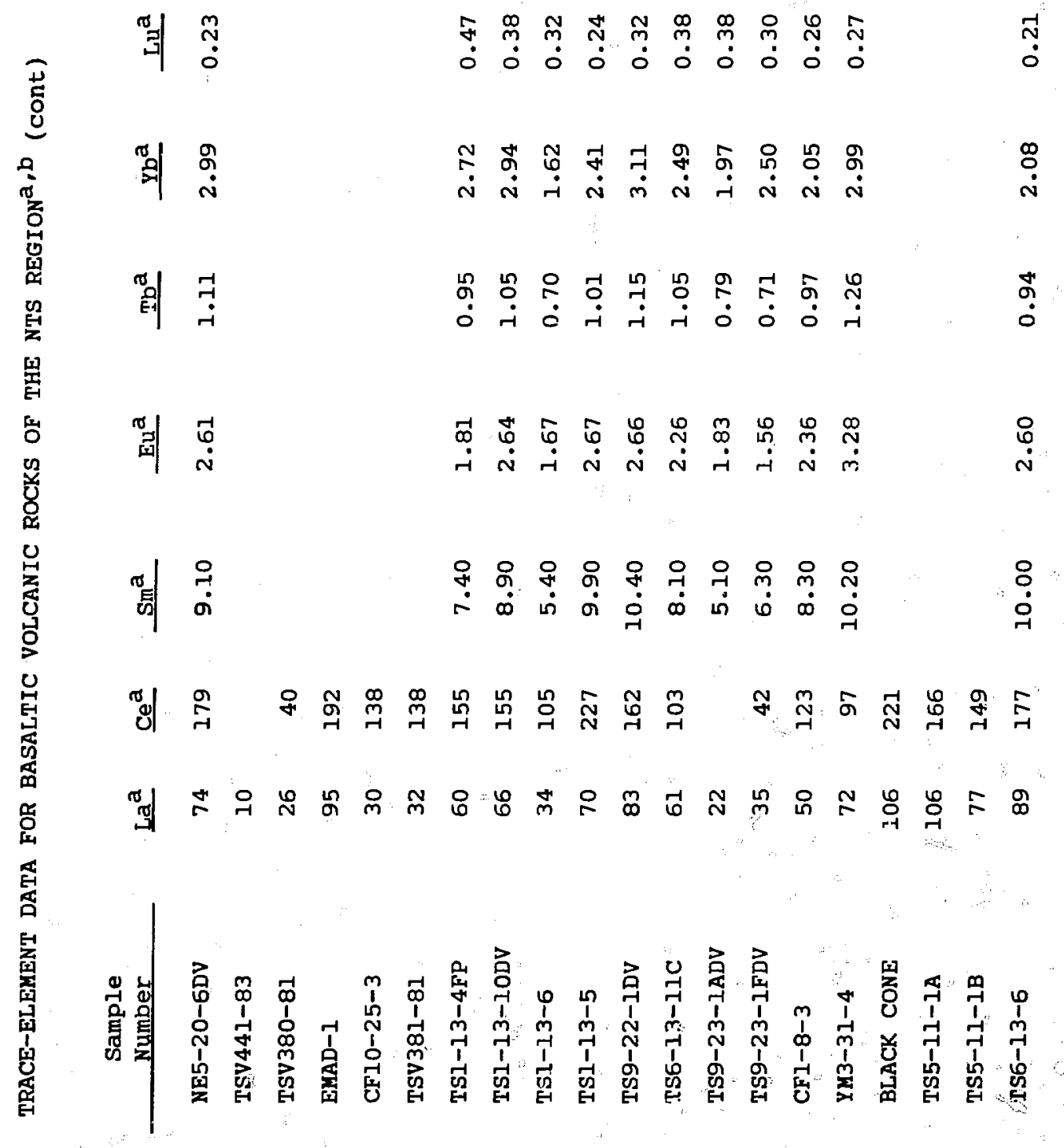




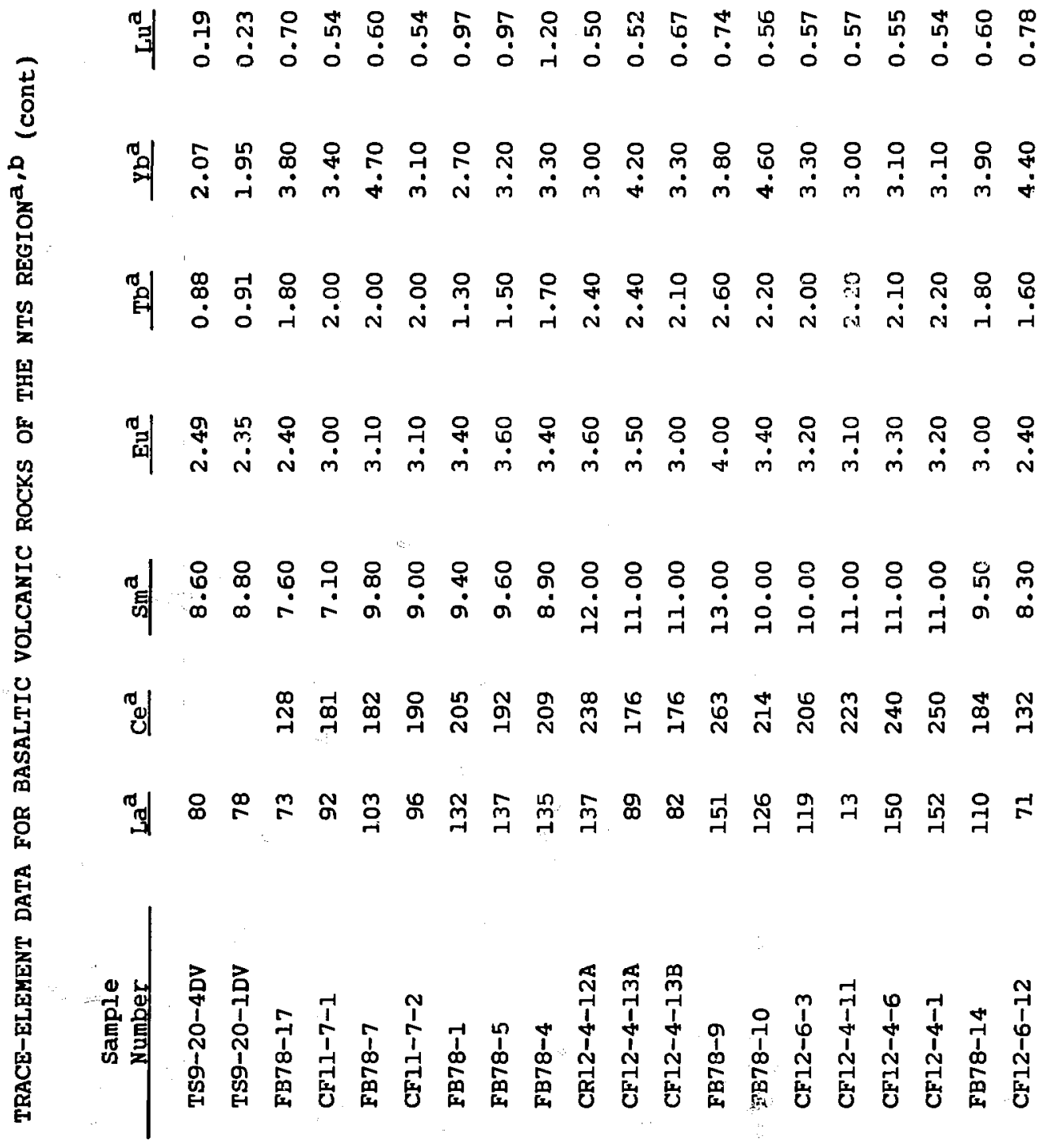


TRACE-ELEMENT DATA FOR BASALTIC VOLCANIC ROCKS OF THE NTS REGIONa,b (cont)

\begin{tabular}{|c|c|c|c|c|c|c|c|}
\hline Number & $\mathrm{La}^{\mathrm{a}}$ & $C \mathrm{e}^{\mathrm{a}}$ & $\mathrm{Sm}^{\mathrm{a}}$ & $E u^{a}$ & $T_{b^{a}}$ & $Y b^{a}$ & $\mathrm{Lu}^{\mathrm{a}}$ \\
\hline CF12-7-6 & 72 & 141 & 8.50 & 2.70 & 1.80 & 3.90 & 0.76 \\
\hline CF12-7-8 & 82 & 153 & 7.40 & 2.90 & 1.80 & 3.40 & 1.50 \\
\hline CF12-6-10 & 72 & 132 & 8.30 & 2.40 & 1.90 & 3.60 & 0.75 \\
\hline FB78-15 & 62 & 114 & 7.30 & 2.10 & 1.40 & 5.00 & 0.80 \\
\hline CF12-7-1 & 66 & 131 & 9.40 & 2.80 & 2.10 & 4.60 & 0.90 \\
\hline SB9-21-24A & 116 & & 12.00 & 3.32 & 1.33 & 2.58 & 0.32 \\
\hline SB9-21-8 & 106 & & 11.90 & 3.25 & 1.29 & 2.19 & 0.31 \\
\hline SB9-21-3 & 111 & & 12.30 & 3.19 & 1.50 & 2.29 & 0.30 \\
\hline
\end{tabular}

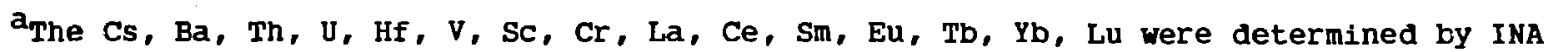
analyses using thermal and epithermal neutron irradiations. The 250-mg aliquots of whole rock powder were loaded into polyethylene vials and irradiated in the Los Alamos Omega Reactor in the following neutron fluxes:

$$
\left(\omega_{\text {Thermal }}=1 \times 10^{13} \text { and } \omega_{\text {Epithermal }}=5 \times 10^{10} \mathrm{~N} / \mathrm{CM}^{2} / \mathrm{s}\right)
$$

All procedures are described in Gladney et al.77-79 Quality assurance was provided by concurrent analyses of USGS and Canadian Certified Reference Materials Project Standards. 80

$\mathrm{b}_{\mathrm{Sr}}, \mathrm{Rb}, \mathrm{Y}, \mathrm{Ni}, \mathrm{Zr}$ determined using a Rigaku 30/64 XRF. Sample preparation, analytical parameters, and detection limits are discussed by Bower. 76 


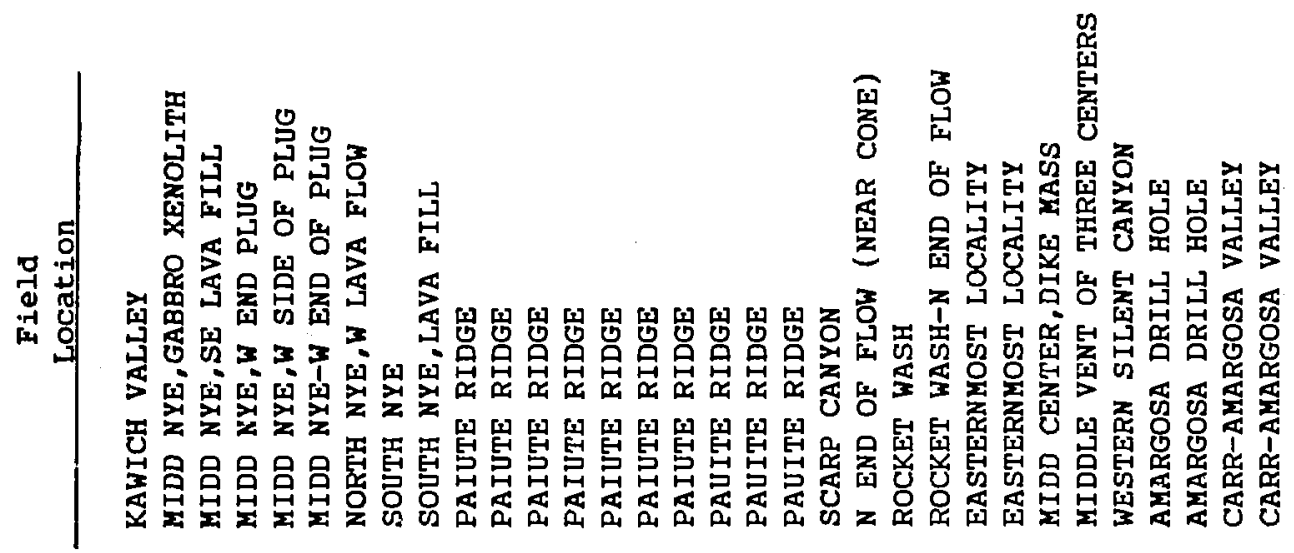

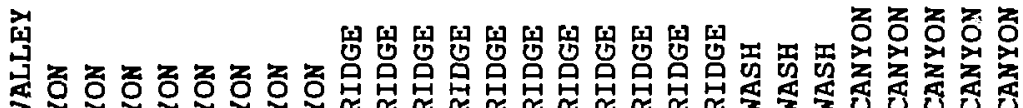

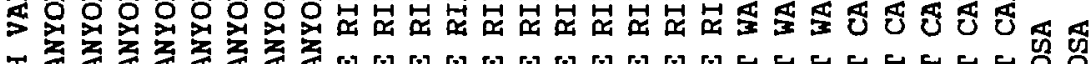

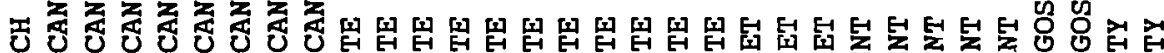

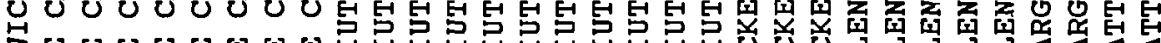

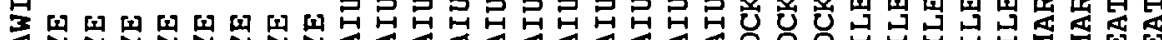

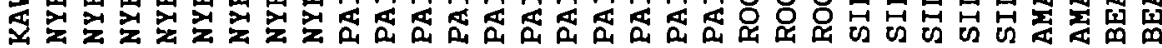

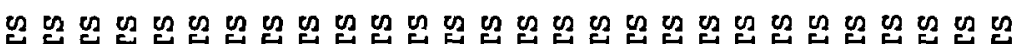

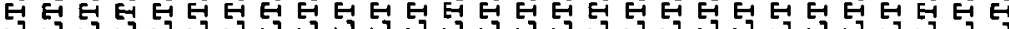

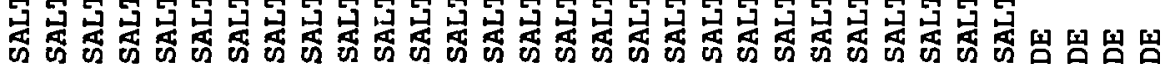

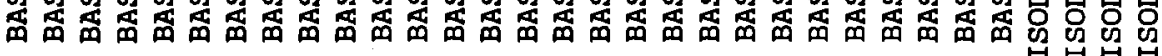

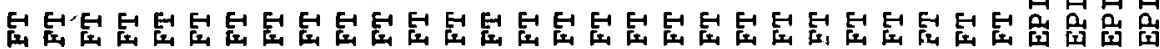

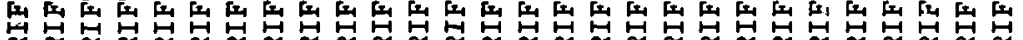

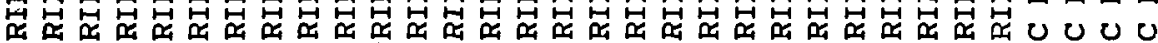

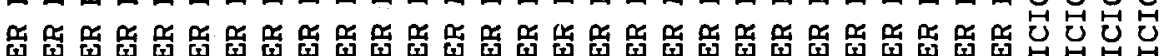

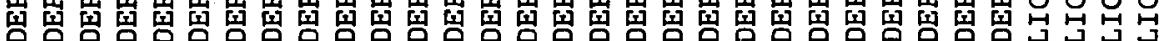

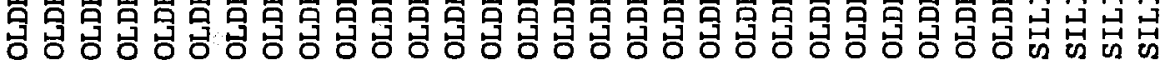

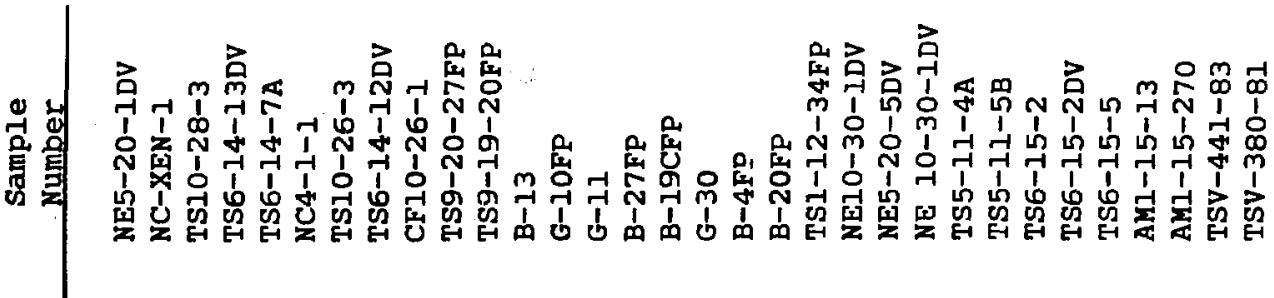




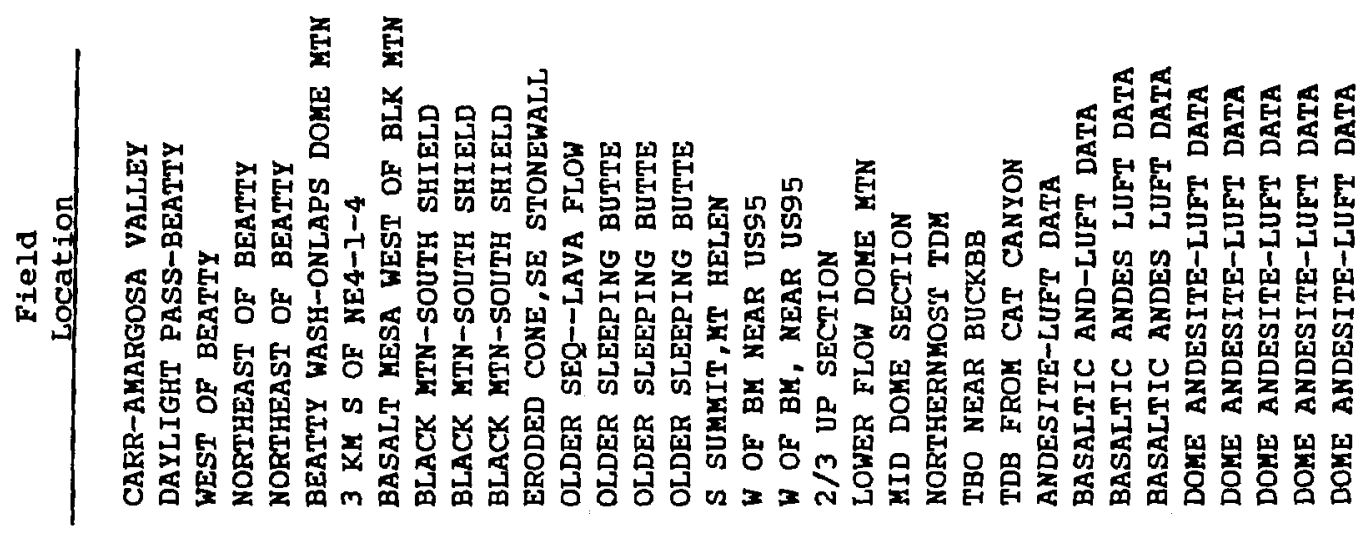

ติด

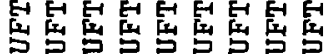

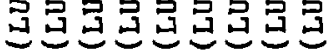

$\rightarrow x \rightarrow x+40$

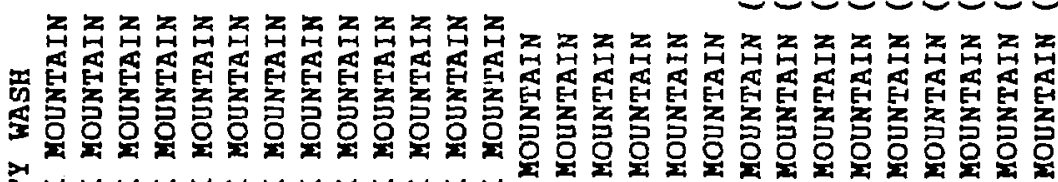

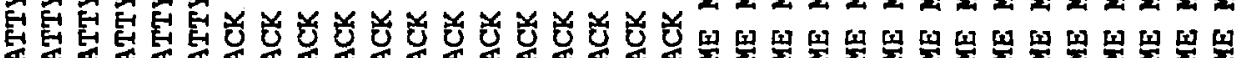

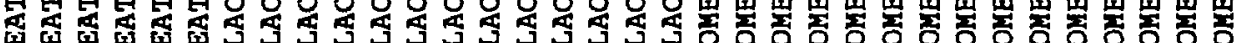

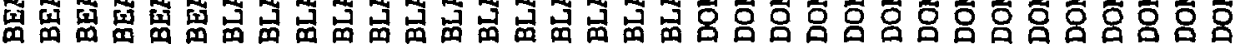

受

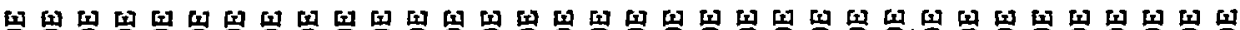

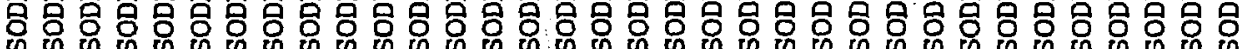

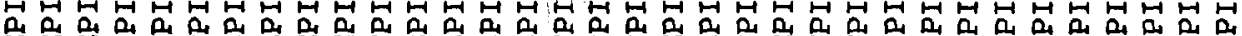

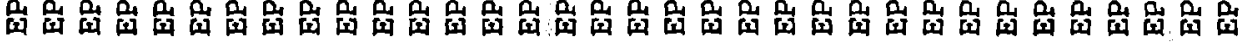

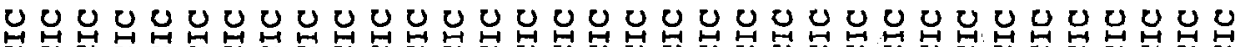

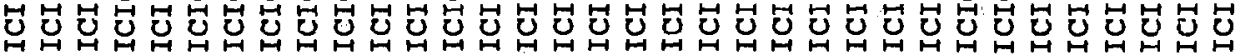

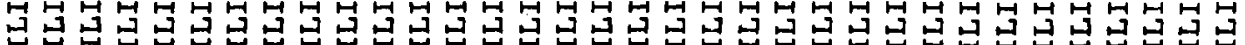

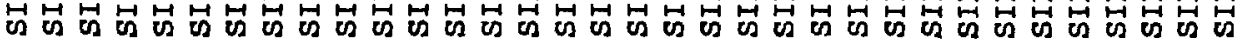

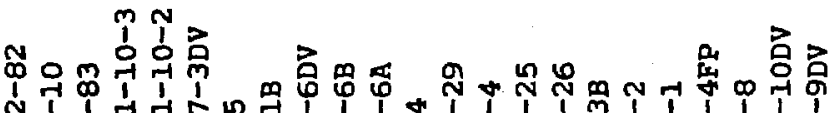

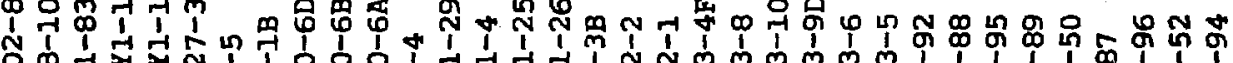

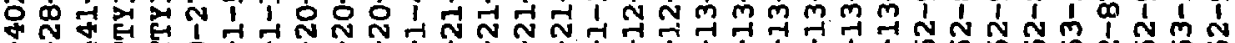
1 I

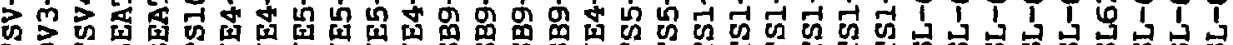

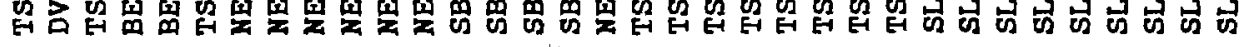


SAMPLE DESCRIPTIONS (cont)

\begin{tabular}{l} 
Sample \\
Number \\
\hline SL-62-86 \\
SL-62-83 \\
SL-62-102 \\
SL-62-99 \\
SL-62-82 \\
SL-62-85 \\
SL-62-84 \\
TM9724A \\
TS6-13-7DV \\
TS9-22-1DV \\
TS6-13-1 \\
EIAD-1 (I) \\
TS6-13-11DBV \\
TS6-13-11C \\
TS9-24-1FP \\
TS9-23-1FP \\
TS9-23-1ADV \\
TS9-23-1DDV \\
TS9-23-1FDV \\
TS9-23-1GDV \\
TS9-23-1HDV \\
TS9-23-1IDV \\
TS9-23-1CDV \\
TS9-23-1EDV \\
TSP-23-1BDV \\
CF10-25-3DV \\
CF1-8-4 \\
CF1-8-3 \\
VH-2-1021 \\
UE19C-1480 \\
TSV380-81 \\
TSV381-81 \\
TSV444A \\
YM3-31-4 \\
\end{tabular}

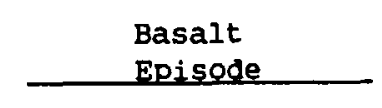

SILICIC EPISODE SILICIC EPISODE SILICIC EPISODE SILICIC EPISODE SILICIC EPISODE SILICIC EPISODE SILICIC EPISODE SILICIC EPISODE SILICIC EPISODE SILICIC EPISODE SILICIC EPISODE SILICIC EPISODE SILICIC EPISODE SILICIC EPISODE SILICIC EPISODE SILICIC EPISODE SILICIC EPISODE SILICIC EPISODE SILICIC EPISODE SILICIC EPISODE SILICIC EPISODE SILICIC EPISODE SILICIC EPISODE SILICIC EPISODE SILICIC EPISODE SILICIC EPISODE SILICIC EPISODE SILICIC EPISODE SILICIC EPISODE SILICIC EPISODE SILICIC EPISODE SILICIC EPISODE SILICIC EPISODE SILICIC EPISODE
Basalt

Group

DOHE MOUNTAIN (LUFT)

DOME YOUNTAIN (LUFT)

DOME MOUNTAIN (LUFT)

DOME MOUNTAIN (LUFT)

DOME MOUNTAIN (LUFT)

DOME MOUNTAIN (LUFT)

DOME MOUNTAIN (LUFT)

DOME MOUNTAIN (LUFT)

JACKASS FLAT

JACKASS FLAT

JACKASS FLAT

JACKASS FLAT

KIWI MESA

KIWI MESA

KIUI MESA

KIWI MESA

LITTLE SKULL MOUNTAIN

LITTLE SKULL MOUNTAIN

LITTLE SKULL MOUNTAIN

LITTLE SKULL MOUNTAIN LITTLE SKULL MOUNTAIN LITTLE SKULL MOUNTAIN LITTLE SKULL MOUNTAIN LITTLE SKULL MOUNTAIN LITTLE SKULL MOUNTAIN OLDER CRATER FLAT OLDER CRATER FLAT OLDER CRATER FLAT OLDER CRATER FLAT PAHUTE MEAS PAPOOSE LAKE PAPOOSE LAKE YUCCA DIKE YUCCA DIKE
Field

Location

DOME BASALT LUFT DATA DOME BASALT-LUF" DATA DOME BASALT-Li \& DATA DOME BASALT-LUFT DATA DOME BASALT-LUFT DATA DOHE MTN-LUFT DATA DOME MTN-LUFT DATA DOME MTN-LUFT DATA JACKASS FLAT JACKASS--RADIO TOWER LITTLE SKULL MTN SITE MIDDLE JACKASS

KIWI MESA, MID FLOW STACK KIWI MESA, MID SEQUENCE

N JACKASS,KIWI EQ NE END OF JACKASS FLAT LITTLE SKULL - BASE LITTLE SKULL ABOVE 23-IC LITTLE SKULL ABOVE 23-EDV LITTLE SKULL ABOVE 23-FDV LITTLE SKULL ABOVE 23-GDV LITTLE SKULL ABOVE 23-GDV LITTLE SKULL-ABOVE 23-IB LITTLE SKULL-ABOVE 23-CDV NEAR BASE OF SEQUENCE 10.5 SITE, S CRATER FLAT S CRATER FLAT (10.5) SOUTHERN CRATER FLAT VH-2 DRILL HOLE PAIUTE MESA CORE IN TIVA ISOLATED BASALT (13.7 NY) ISOLATED BASALT 13.7 \%.Y. BASALT CLAST- $S$ OF TRENCH YUCCA MOUNTAIN DIKE 


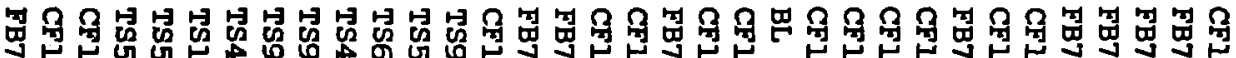

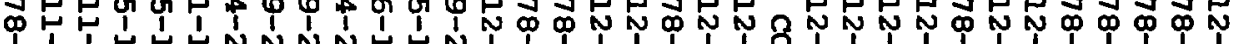

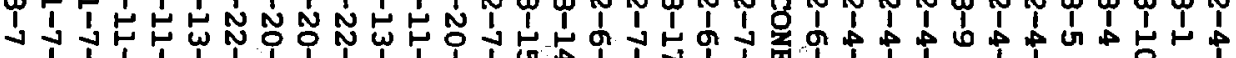

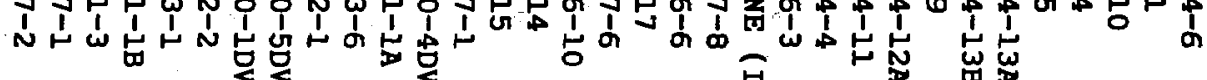

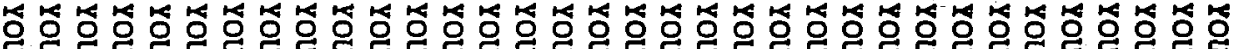

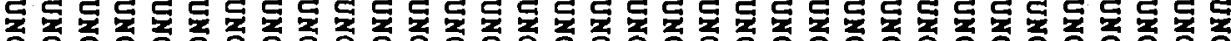
ดดดดดดดด ดดดดดดดดดดดดดดดดดดดดดดดด

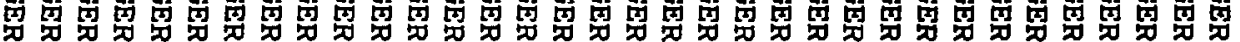

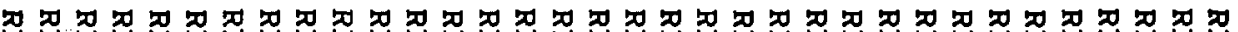

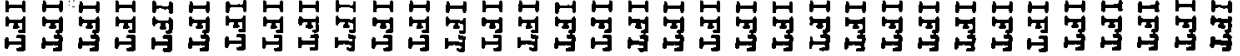

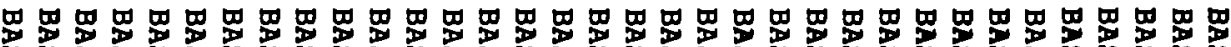

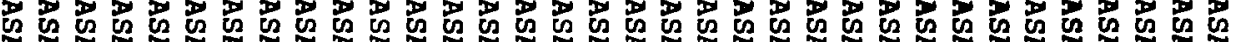

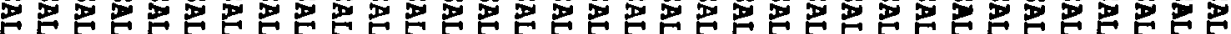

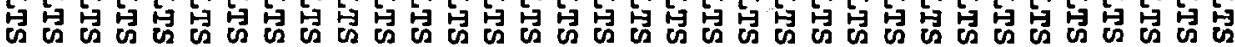

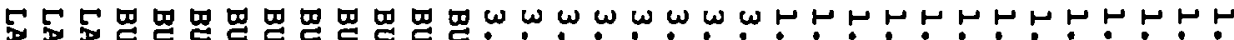

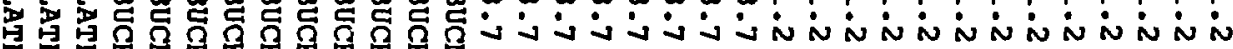

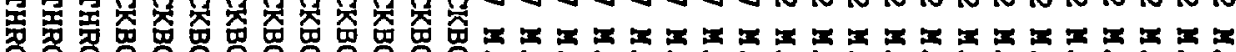

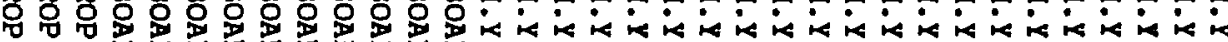

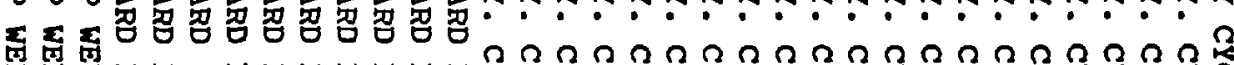

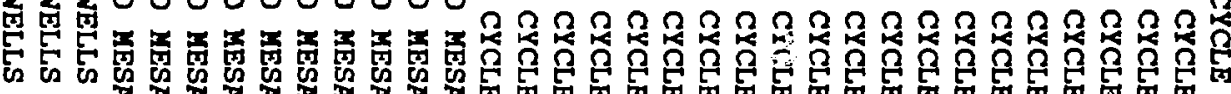

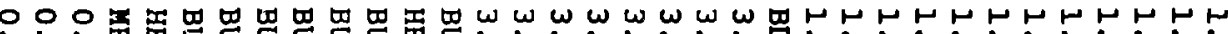

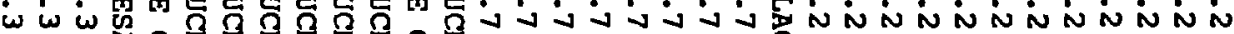

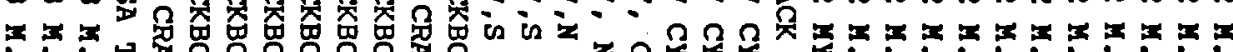

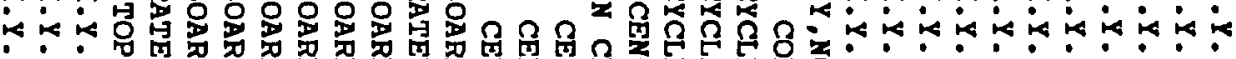

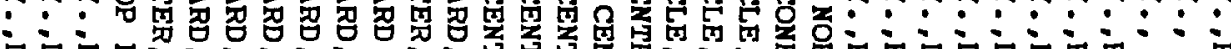

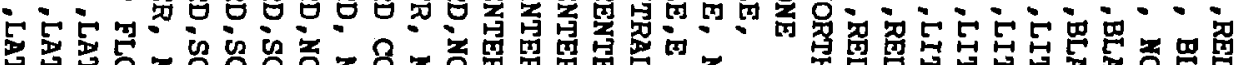

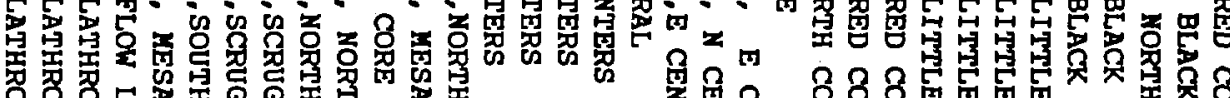

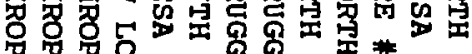
ๆ

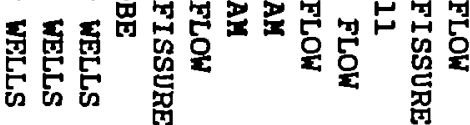

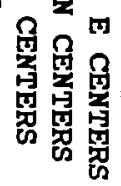

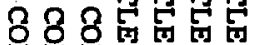
田 量 
SAMPLE DESCRIPTIONS (cont)

\begin{tabular}{ll}
$\begin{array}{c}\text { Sample } \\
\text { Number }\end{array}$ & \multicolumn{1}{c}{$\begin{array}{c}\text { Basalt } \\
\text { Episode }\end{array}$} \\
\cline { 3 - 3 } SB9-21-34 & \\
SB9-21-6 & YOUNGER RIFT BASALTS \\
SB9-21-36 & YOUNGER RIFT BASALTS \\
SB9-21-8 & YOUNGER RIFT BASALTS \\
SB9-21-20 & YOUNGER RIFT BASALTS \\
SB9-21-27 & YOUNGER RIFT BASALTS \\
SB9-21-22 & YOUNGER RIFT BASALTS \\
SB9-21-24B & YOUNGER RIFT BASALTS \\
SB9-21-24A & YOUNGER RIFT BASALTS \\
SB9-21-28 & YOUNGER RIFT BASALTS \\
SB9-21-3 & YOUNGER RIFT BASALTS \\
SB9-21-5 & YOUNGER RIFT BASALTS \\
SB9-21-1 & YOUNGER RIFT BASALTS
\end{tabular}

Basalt
Group

SLEEPING BUTTE

SLEEPING BUTTE

SLEEPING BUTTE

SLEEPING BUTTE

SLEEPING BUTTE

SLEEPING BUTTE

SLEEPING BUTTE

SLEEPING BUTTE

SLEEPING BUTTE

SLEEPING BUTTE

SLEEPING BUTTE

SLEEPING BUTTE

SLEEPING BUTTE
Field

Location

SL BUTTE SW,BOMB IN CONE SL BUTTE SW,EASTERH FLOW SL BUTTE SW,W FLOW

SL BUTTE SW,WESTERN FLOW SL BUTTE,NE,DIKE,E FLOW

SL BUTTE,NE,EASTERN FLOW SL BUTTE,NE,EASTERN FLOW SL BUTTE, NE, EASTERN FLOW SL BUTTE, NE,EASTERN FLOW SL BUTTE, NE, WESTERN FLOW SL BUTTE,W FLOW LOBE SL BUTTE-DIKE IN SW CONE SLEEPING BUTTE,NE,BOMB 
APPENDIX E

GRAIN-SIZE DATA FOR BASALTIC TEPHI'A FROH LATHROP WELLS BASALT CENTER

Sample Number: LW-la Sample Description: Nonbedded, fine ash, Lathrop Wells scoria cone, quarry wall exposure.

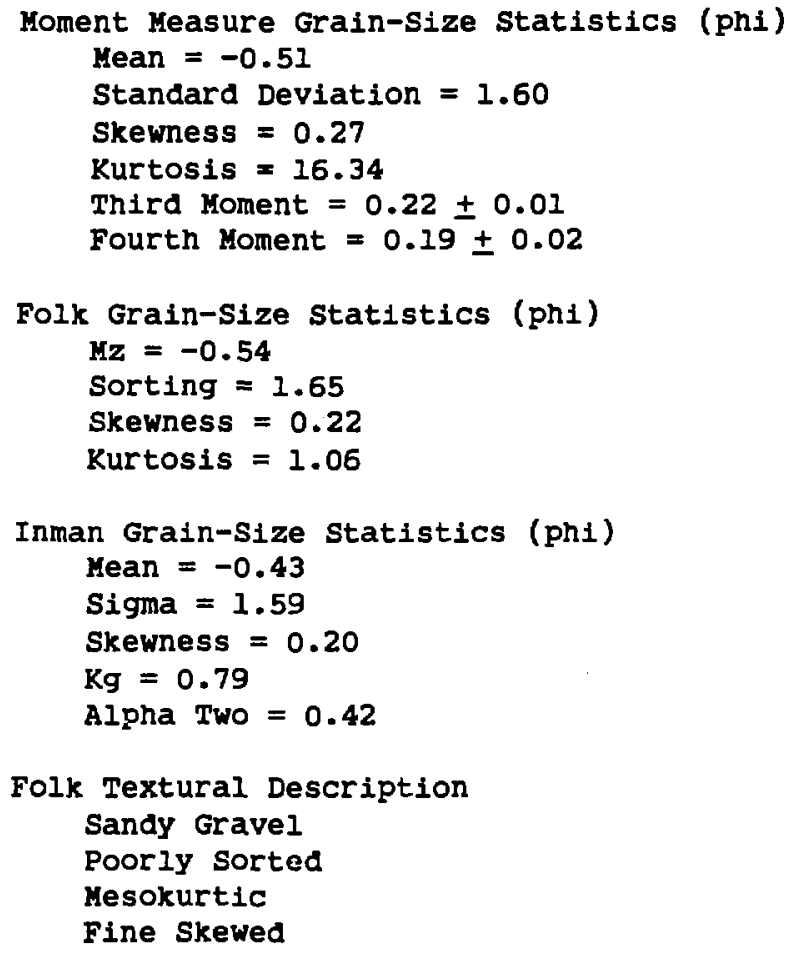

Phi Size

$-3.0$

$-2.50$

$-2.0$

$-1.50$

$-1.0$

$-0.50$

0.0

0.50

1.0

1.50

2.0

2.50

3.0

3.50

4.0

4.50

5.0
Fraction (t)
4.44
4.64
7.26
12.90
14.72
12.00
9.07
8.97
8.17
5.54
3.83
2.42
1.92
1.41
1.01
0.60
1.11 
GRAIN-SIZE DATA FOR BASALTIC TEPHRA FROM LATHROP WELLS BASALT CENTER (cont)

Sample Number: LW-1B Sample Description: Nonbedded, fine ash, Lathrop Wells scoria cone, quarry wall exposure.

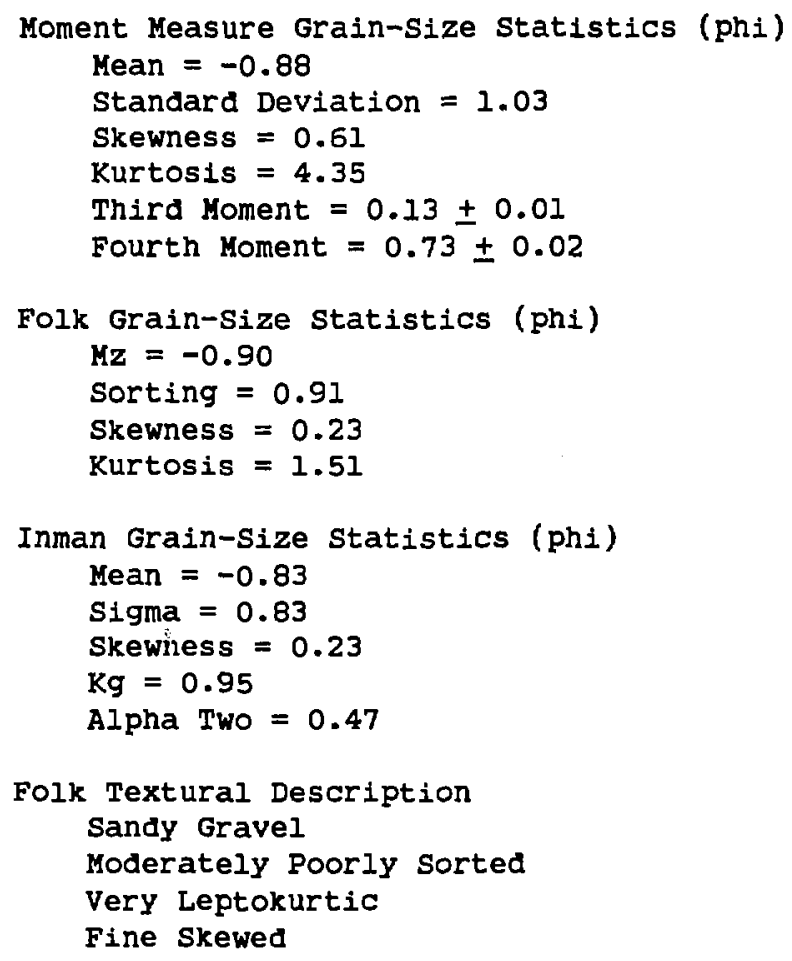

1.35

1.93

4.51

14.13

29.89

25.38

6.80

5.27

4.75

2.05

0.76

0.35

0.35

0.41

0.29

0.23

0.53 
GRAIN-SIZE DATA FOR BASALTIC TEPHRA FROM LATHROP WELLS BASALT CENTER (cont)

Sample Number: LW-2A Sample Description: Strombolian air-fall deposit, Lathrop Wells scoria cone, quarry wall exposure.

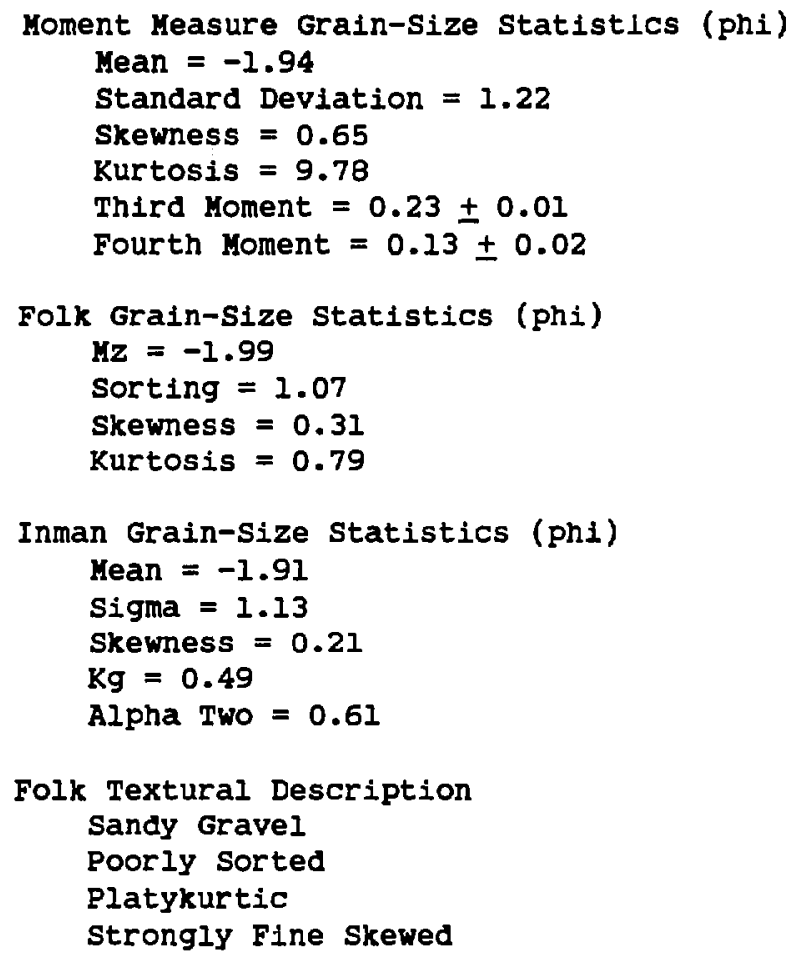

\section{Phi Size}

$$
\begin{aligned}
& -3.0 \\
& -2.50 \\
& -2.0 \\
& -1.50 \\
& -1.0 \\
& -0.50 \\
& 0.0 \\
& 0.50 \\
& 1.0 \\
& 1.50 \\
& 2.0 \\
& 2.50 \\
& 3.0 \\
& 3.50 \\
& 4.0 \\
& 4.50 \\
& 5.0
\end{aligned}
$$

Fraction (7)

23.20

16.81

14.30

14.22

10.59

10.22

4.61

2.88

1.07

0.45

0.16

0.21

0.25

0.37

0.21

0.16

0.29 
Sample Number: LW-2B Sample Description: Strombolian air-fall deposit, Lathrop Wells scoria cone, quarry wall exposure.

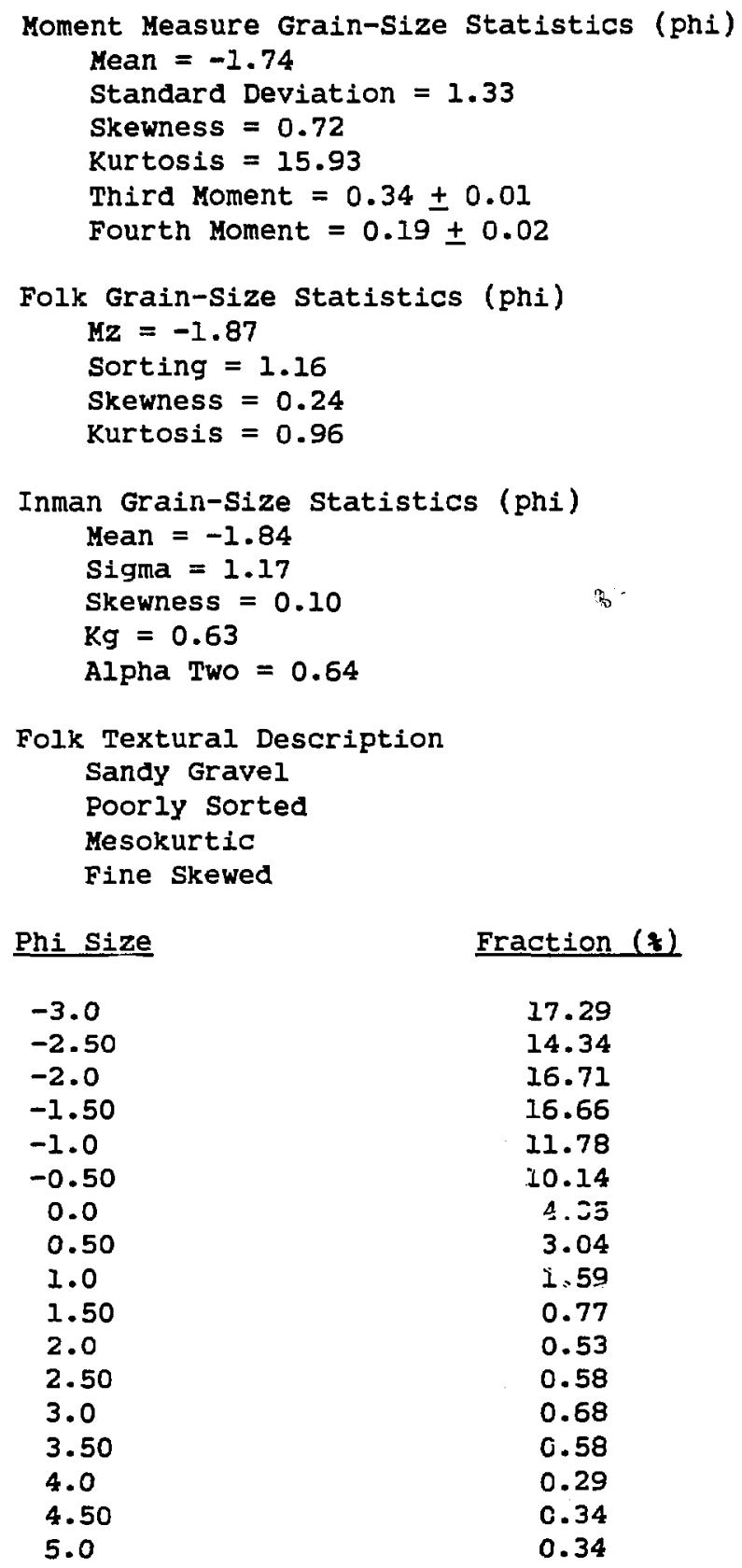


Sample Number: LW-3 Sample Description: Nonbedded fine ash, Lathrop wells scorla cone, quarry wall exposure.

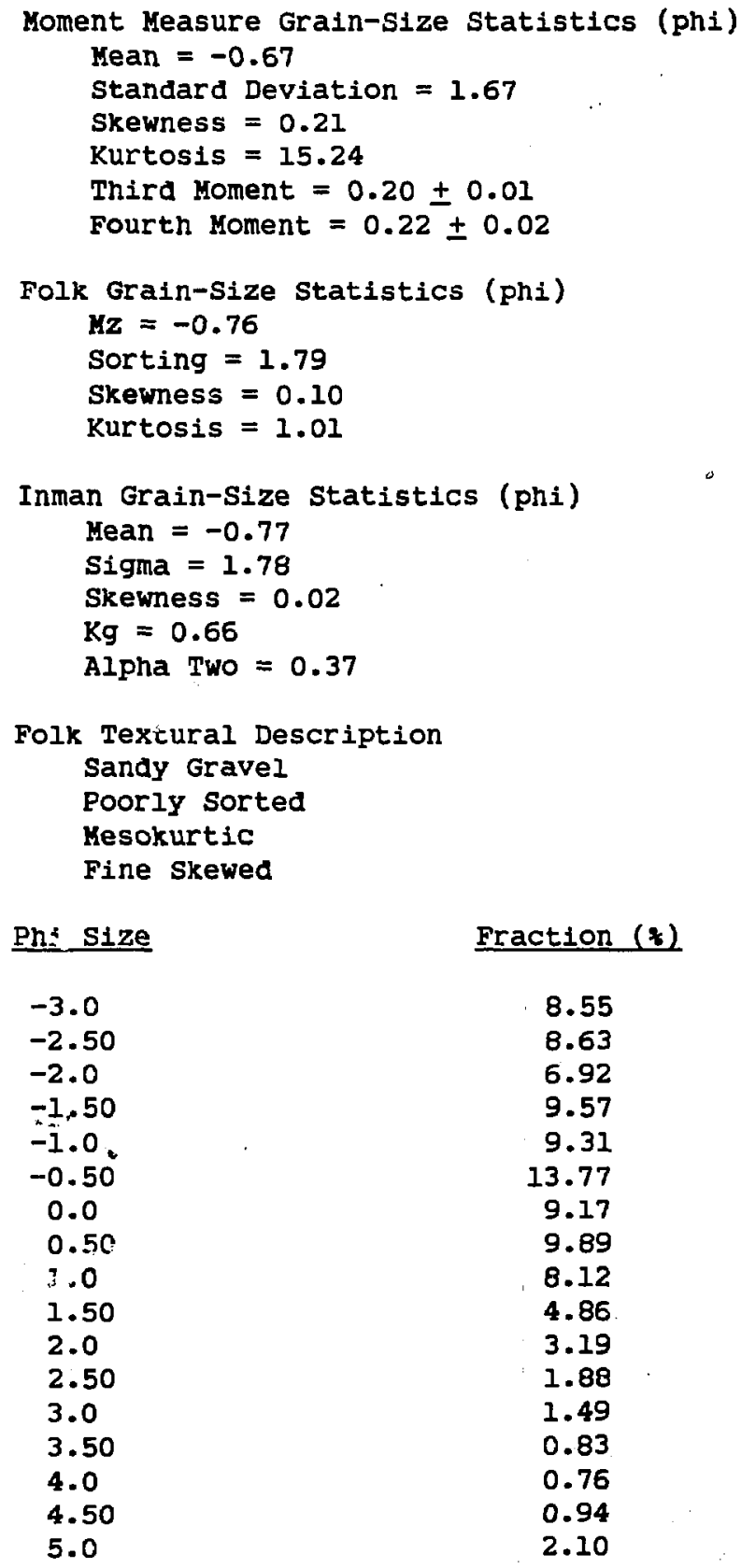


Sample Number: LW-4 Sample Description: Strombolian air-fall deposit, Lathrop Wells scoria cone, quarry wall exposure.

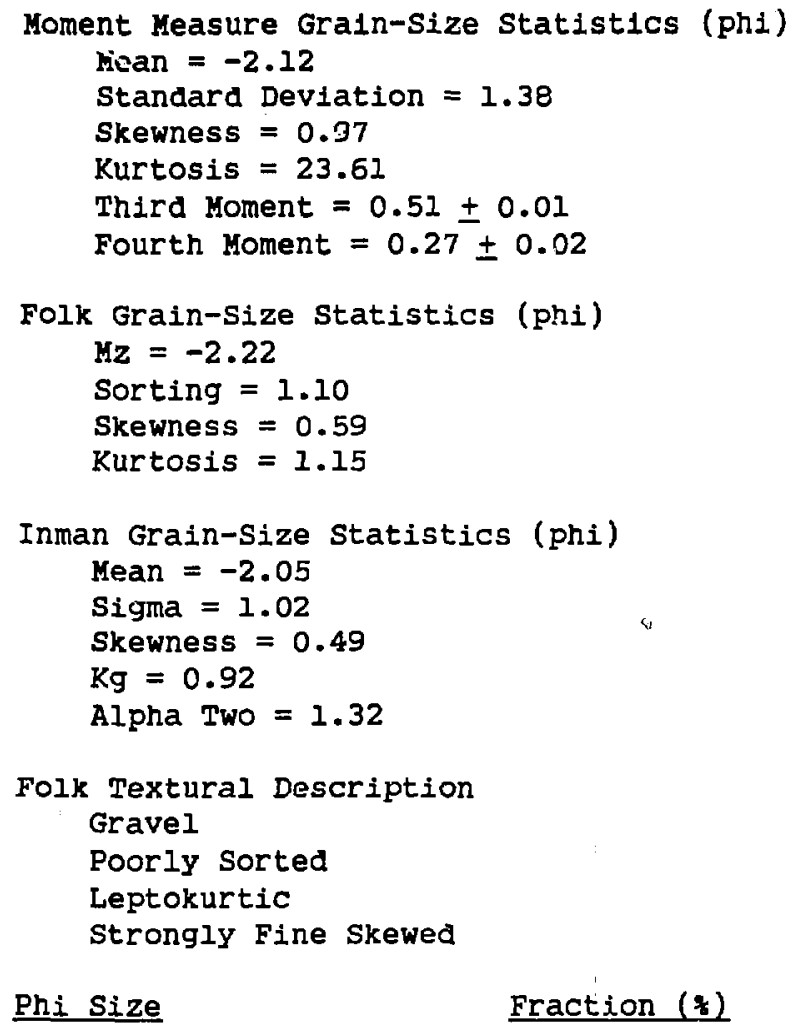


GRAIN-SIZE DATA FOR BASALTIC TEPHRA FROM LATHROP WELLS BASALT CENTER (cont)

Sample Number: LW-5 Sample Descripition: Nonbedded fine ash, pyroclastic surge deposit, Lathrop wells scoria cone, quarry wall exposure.

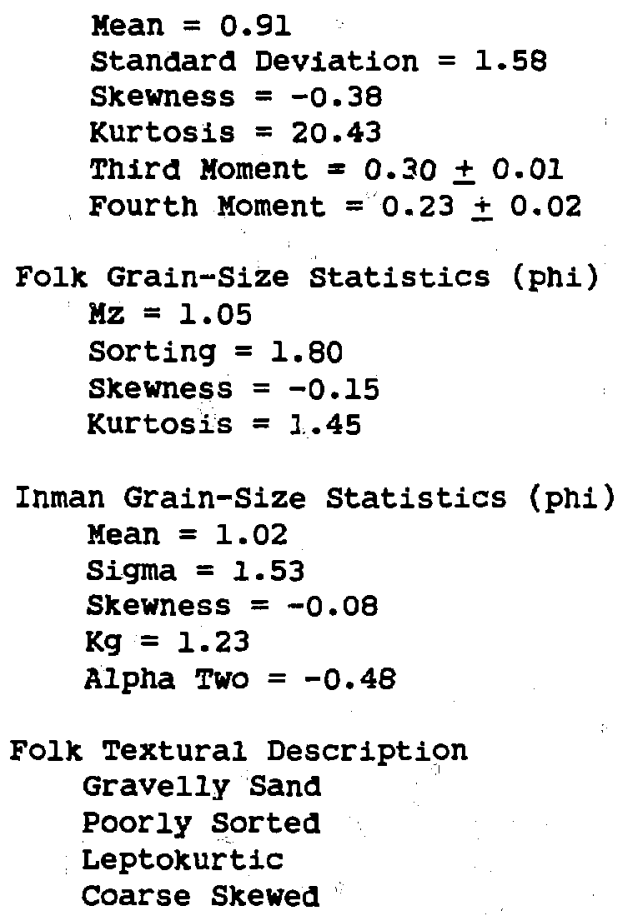

Phi Size

Fraction ( $(t)$

$-3.0$

5.04

$-2.50$

0.62

$-2.0$

0.55

$-1.50$

1.37

$-1.0$

2.26

$-0.50$

6.33

0.0

6.17

0.50

9.68

1.0

13.98

1.50

14.53

2.0

2.50

1.3.08

3.0

9.57

7.97

3.50

3.01

4.0

1.33

4.50

1.44

5.0

3.08 
Sample Nunber: LW-6 Sample Description: Nonbedded fine ash, pyroclastic surge deposit, Lathrop Wells scoria cone, quarry wall exposure.

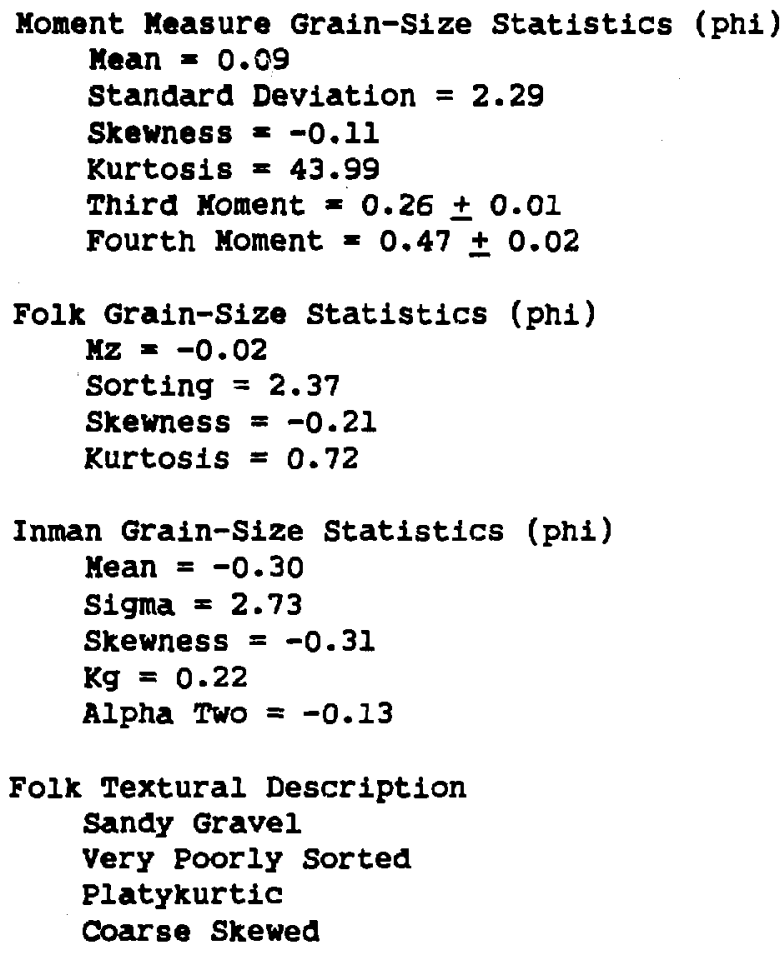

Phi size

$-3.0$

$-2.50$

$-2.0$

$-1.50$

$-1.0$

$-0.50$

0.0

0.50

1.0

1.50

2.0

2.50

3.0

3.50

4.0

4.50

5.0
Fraction ( 7 )

20.73

1.56

2.48

2.11

3.58

6.06

5.05

7.52

9.63

10.18

9.17

6.79

6.42

3.67

1.93

2.11

1.01 
Sample Number: LW-7 Sample Description: Strombolian air-fall deposit, Lathrop Wells acorla cone, quarry wall exposure.

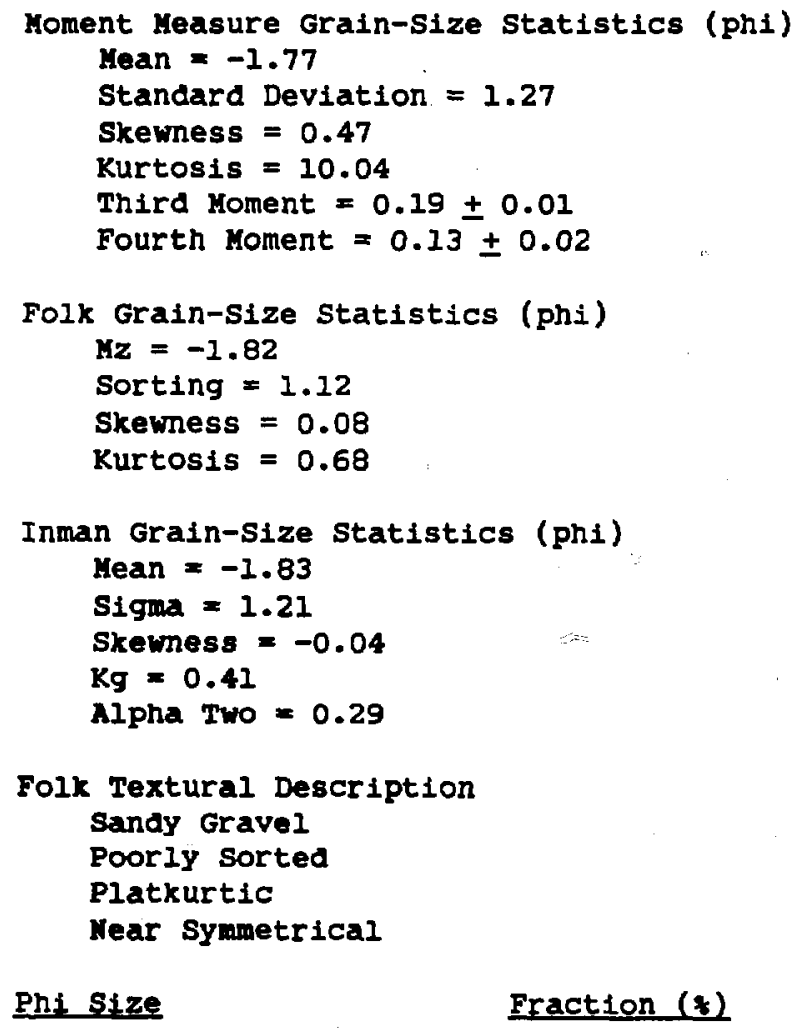

Phi size

Fraction (f)

$-3.0$

$-2.50$

$-2.0$

$-1.50$

$-1.0$

$-0.50$

0.0

0.50

1.0

1.50

2.0

2.50

3.0

3.50

4.0

4.50

5.0

$$
\begin{array}{r}
24.44 \\
10.84 \\
9.35 \\
12.59 \\
14.34 \\
15.54 \\
6.10 \\
3.65 \\
1.50 \\
0.30 \\
0.05 \\
0.10 \\
0.10 \\
0.35 \\
0.30 \\
0.30 \\
0.15
\end{array}
$$


GRAIN-SIZE DATA FOR BASNLTIC TEPHRA FROK LATHROP WELLS BASALT CENTER (cont)

Sample Number: LW-8 Sample Description: Cross-bedded, fine ash, pyroclastic surge deposit, Lathrop Wells scoria cone, quarry wall exposure.

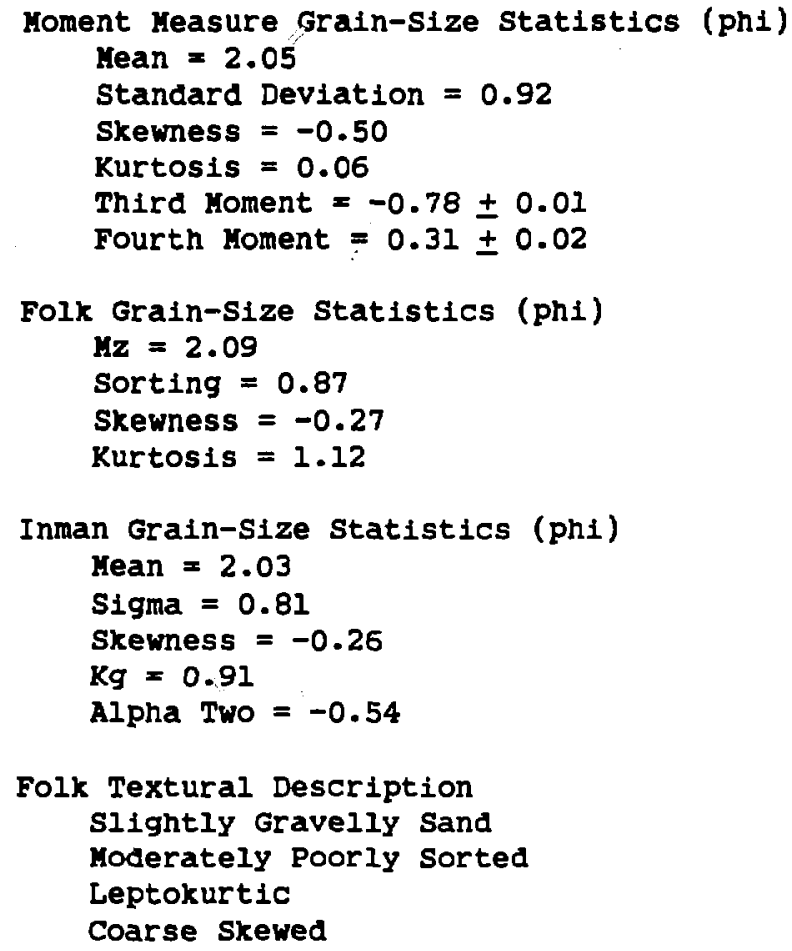

Phi Size

$$
\begin{aligned}
& -3.0 \\
& -2.50 \\
& -2.0 \\
& -1.50 \\
& -1.0 \\
& -0.50 \\
& 0.0 \\
& 0.50 \\
& 1.0 \\
& 1.50 \\
& 2.0 \\
& 2.50 \\
& 3.0 \\
& 3.50 \\
& 4.0 \\
& 4.50 \\
& 5.0
\end{aligned}
$$

Fraction ( 8 )
0.00
0.00
0.00
0.14
0.73
1.08
1.91
2.71
5.07
12.02
15.81
20.35
30.43
7.12
1.11
0.31
0.35 
GRAIM-SIZE DATA FOR BASALTIC TEPHRA FROM LATHROP WELLS BASALT CENTER (cont)

Sample Number: LW-9 Sample Description: Cross-bedded fine ash, pyroclastic surge deposit, Lathrop Wells scoria cone, quarry wall exposure.

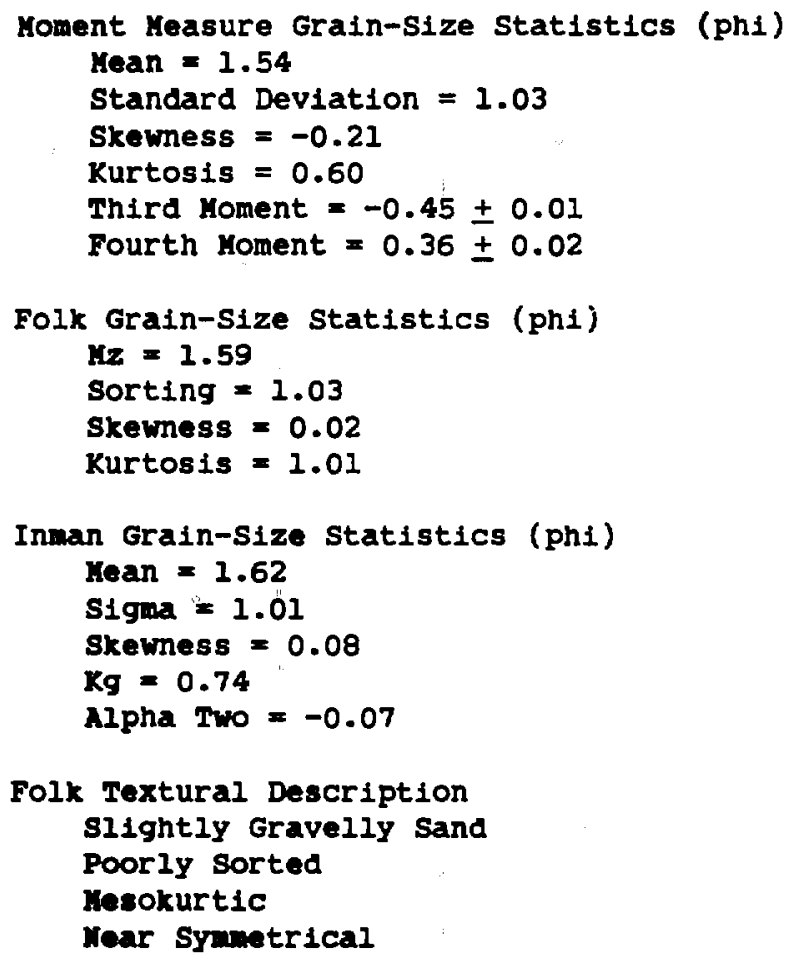

\section{Phi Size}

$$
\begin{aligned}
& -3.0 \\
& -2.50 \\
& -2.0 \\
& -1.50 \\
& -1.0 \\
& -0.50 \\
& 0.0 \\
& 0.50 \\
& 1.0 \\
& 1.50 \\
& 2.0 \\
& 2.50 \\
& 3.0 \\
& 3.50 \\
& 4.0 \\
& 4.50 \\
& 5.0
\end{aligned}
$$

Fraction ( 8 )
0.00
0.00
0.07
0.59
0.92
2.31
3.03
6.20
14.77
20.83
16.35
13.78
15.03
4.94
0.59
0.20
0.40 


\section{APPENDIX $F$}

TEPHRA CONSTITUENT DATA FOR LATHROP WELLS SAMPLES ${ }^{a}$

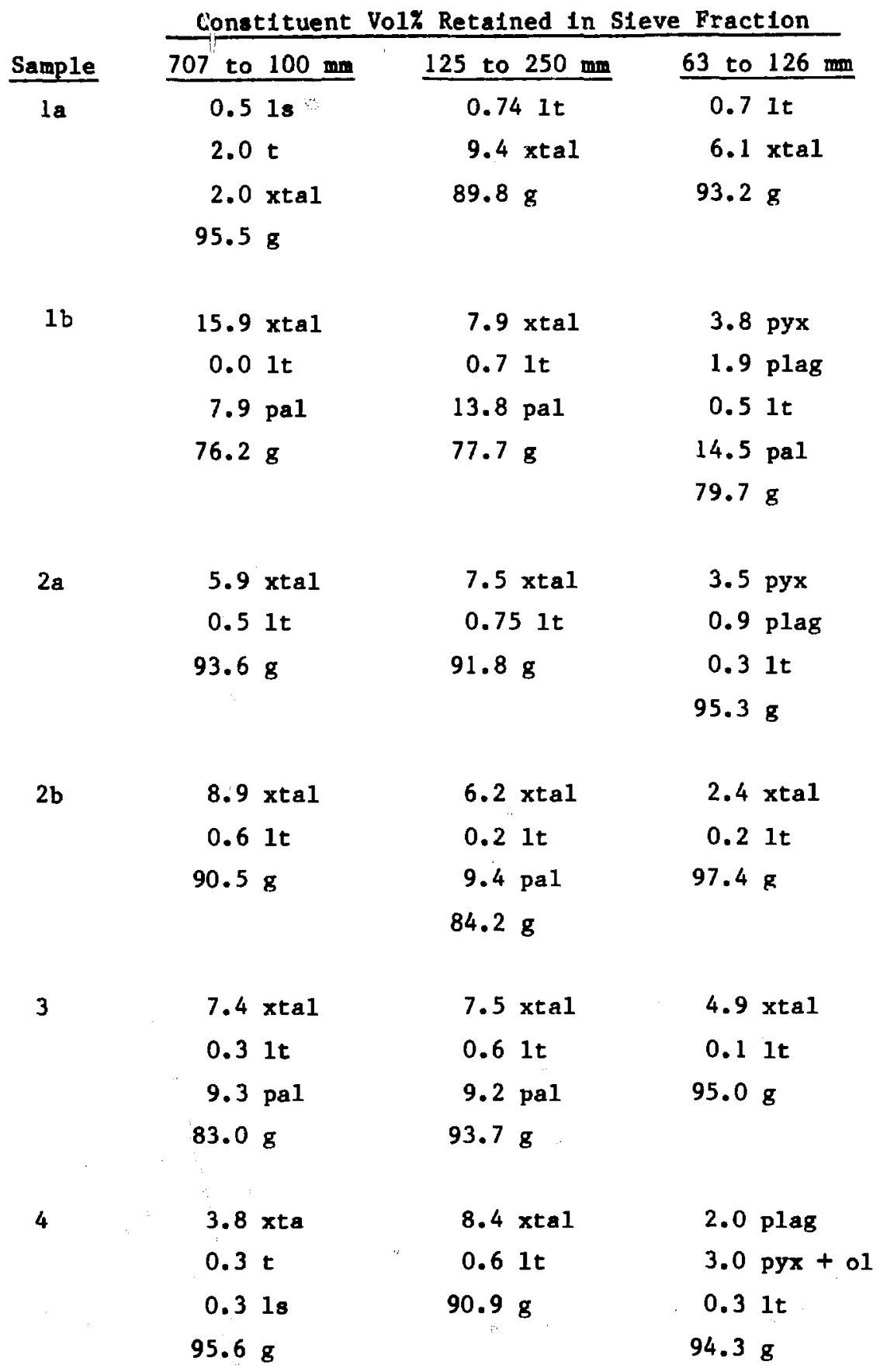


TEPHRA CONSTITUENT DATA FOR LATHROP WELLS SAMPLES ${ }^{a}$ (cont)

Constituent Vo1\% Retained in Sieve Fraction

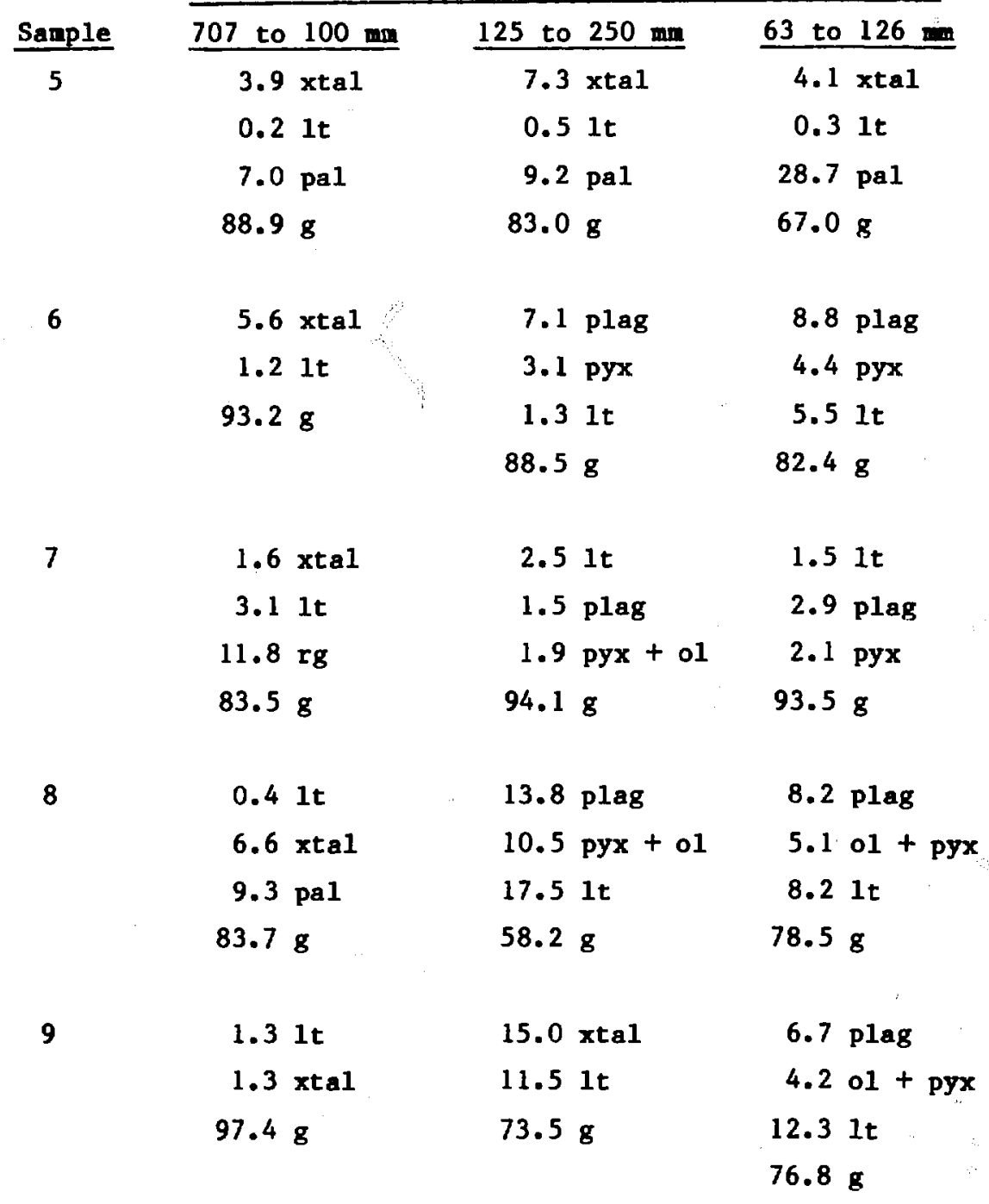

\footnotetext{
${ }^{a}$ Constituent abbreviations: $x$ xal = undifferentiated crystals, plag = plagloclase, pyx = pyroxene, ol = olivine, $1 t=$ undifferentiated 11thics, 18 - linestone, $t=$ tuff, $g$ = black to reddish brom glass, rg = red glass, and pal = palagonite.
} 
APPENDIX G

SEM TEXTURAL DESCRIPTION FOR LATHROP WELLS SAMPLES ${ }^{a}$

\begin{tabular}{|c|c|c|c|c|c|}
\hline Sanple & Ves1cles & $\begin{array}{l}\text { Blocky } \\
\text { Shape } \\
\end{array}$ & Fused & $\begin{array}{c}\text { Altered } \\
\text { Part1cles } \\
\end{array}$ & Roundness \\
\hline $1 \mathrm{a}$ & 0.28 & 0.70 & 0.03 & 0.41 & 0.32 \\
\hline $1 b$ & 0.26 & 0.56 & 0.18 & 0.52 & 0.47 \\
\hline $2 a$ & 0.58 & 0.33 & 0.08 & 0.25 & 0.15 \\
\hline $2 b$ & 0.63 & 0.35 & 0.02 & 0.18 & 0.24 \\
\hline 3 & 0.56 & 0.38 & 0.06 & 0.35 & 0.38 \\
\hline 4 & 0.42 & 0.42 & 0.17 & 0.30 & 0.30 \\
\hline 5 & 0.46 & 0.54 & 0.0 & 0.72 & 0.47 \\
\hline 6 & 0.28 & 0.62 & 0.06 & 0.19 & 0.56 \\
\hline 7 & 0.55 & 0.34 & 0.11 & 0.29 & 0.47 \\
\hline 8 & 0.21 & 0.70 & 0.09 & 0.62 & 0.57 \\
\hline 9 & 0.21 & 0.53 & 0.26 & 0.58 & 0.74 \\
\hline
\end{tabular}

${ }^{a}$ Values shown are the fraction of the total number of grains counted per sample (50). 
